ORNL/TM-11838

OAK RIDGE

NATIONAL

LABORATORY

WMARTIN MARIETRA

\section{In Situ Grouting of Low-Level Burial Trenches with a Cement-Based Grout at Oak Ridge National Laboratory}

C. W. Francis

R. D. Spence

T. Tamura

B. P. Spalding

Environmental Sciences Division

Publication No. 3872

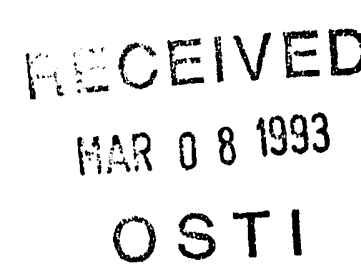

MANAGED BY

MARTIN MARIETTA ENERGY SYSTEMS, INC.

FOR THE UNITED STATES

DEPARTMENT OF ENERGY

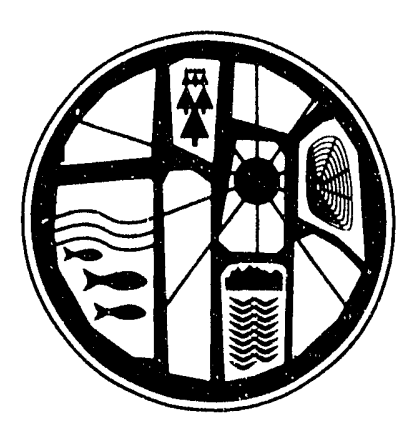


This report has been reproduced directly from the best available copy.

Available to DOE and DOE contractors from the Office of Scientific and Technical Information, P.O. Box 62, Oak Ridge. TN 37831; prices avaliable from (615) 576-8401, FTS 626-8401.

Available to the public from the National Technical Information Service, U.S. Department of Commerce, 5285 Port Royal Rd., Springfield, VA 22161.

This report was prepared as an account of work sponsored by an agency of the United States Government. Neither the United States Government nor any agency thereof, nor any of their employees, makes any warranty, express or implied, or assumes any legal liability or responsibility for the accuracy, completeness, or usefulness of any information, apparatus, product, or process disclosed, or represents that its use would not infringe privately owned rights. Reference herein to any specific commercial product, process, or si vice by trade name, trademark, manufacturer, or otherwise, does not necessarily constitute or imply its endorsement, recommendation, or favoring by the United States Government or any agency thereof. The views and opinions of authors expressed herein do not necessarily state or reflect those of the United States Government or any agency thereot. 
Environmental Sciences Division

\section{In Situ Grouting of Low-Level Burial Trenches with a Cement-Based Grout at Oak Ridge National Laboratory}

C. W. Francis

R. D. Spence ${ }^{a}$

T. Tamura ${ }^{b}$

B. P. Spalding

Environmental Sciences Division Publication No. 3872

${ }^{a}$ Chemical Technology Division

${ }^{b}$ Hazwrap Program

Date Published_January 1993

Prepared for the Office of T'echnology Development

(EW 401050 0; 3TAG000)

Prepared by the

OAK RIDGE NATIONAL LABORATORY

Oak Ridge, Tennessee 37831-6285

managed by

MARTIN MARIETTA ENERGY SYSTEMS, INC. for the

U.S. Department of Energy

under contract DE-ACO5-84OR21400

\section{MASTER}




\section{CONTENTS}

LIST OF FIGURES $\ldots \ldots \ldots \ldots \ldots \ldots \ldots \ldots \ldots \ldots \ldots \ldots$

LIST OF TABLES $\ldots \ldots \ldots \ldots \ldots \ldots \ldots \ldots \ldots \ldots \ldots \ldots$ vii

ABSTRACT $\ldots \ldots \ldots \ldots \ldots \ldots \ldots \ldots \ldots \ldots \ldots \ldots \ldots \ldots \ldots \ldots \ldots \ldots \ldots \ldots \ldots$

1. INTRODUCTION $\ldots \ldots \ldots \ldots \ldots \ldots \ldots \ldots \ldots \ldots \ldots \ldots \ldots$

2. METHODS AND MATERIALS $\ldots \ldots \ldots \ldots \ldots \ldots \ldots \ldots \ldots \ldots$

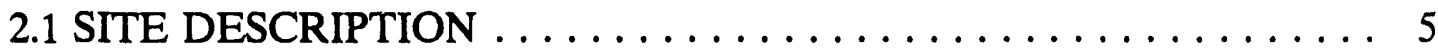

2.2 SOIL-PENETRATION TESTS $\ldots \ldots \ldots \ldots \ldots \ldots \ldots \ldots \ldots \ldots$

2.3 INSTALLATION OF INJECTION WELLS $\ldots \ldots \ldots \ldots \ldots \ldots \ldots$

2.4 HYDRAULIC CONDUCTIVITY MEASUREMENTS $\ldots \ldots \ldots \ldots 8$

2.4.1 Pregrouted Trenches $\ldots \ldots \ldots \ldots \ldots \ldots \ldots \ldots \ldots . \ldots$

2.4.2 Postgrouted Trenches ................... 9

2.5 VOID-VOLUME MEASUREMENTS $\ldots \ldots \ldots \ldots \ldots \ldots \ldots \ldots$

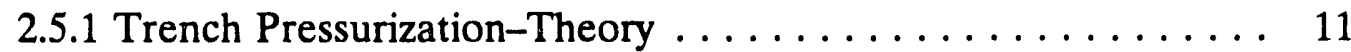

2.5.2 Trench Pressurization-Applied ............... 14

2.5.3 Water Pump-In Tests ...................... 15

2.6 GROUNDWATER MONITORING $\ldots \ldots \ldots \ldots \ldots \ldots \ldots \ldots 20$

2.7 GROUT FORMULATION AND TESTING $\ldots \ldots \ldots \ldots \ldots \ldots, 20$

2.7.1 Phase Separation Tests .................. 21

2.7.2 Compressive Strength Tests $\ldots \ldots \ldots \ldots \ldots \ldots \ldots \ldots . \ldots \ldots 21$

2.7.3 Penetration Resistance ................... 22

2.7.4 Apparent Viscosity ..................... 22

2.7 .5 Gel Strength . . . . . . . . . . . . . . . . . . . 22

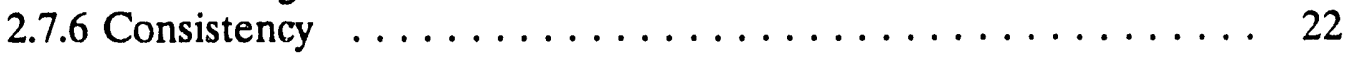

2.8 FIELD GROUT MIXING AND INJECTION $\ldots \ldots \ldots \ldots \ldots \ldots 23$

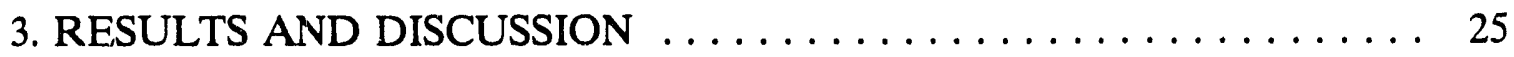

3.1 SELECTION OF GROUT FORMULATION $\ldots \ldots \ldots \ldots \ldots \ldots, 25$

3.2 SOIL-PENETRATION TESTS $\ldots \ldots \ldots \ldots \ldots \ldots \ldots \ldots \ldots, 26$

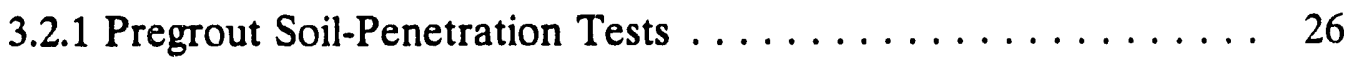

3.2.2 Postgrouting Soil-Penetration Tests $\ldots \ldots \ldots \ldots \ldots \ldots \ldots 28$

3.3 VOID VOLUME MEASUREMENTS . . . . . . . . . . . . . 29

3.3.1 Preliminary Pressurization Tests . . ............. 29

3.3.2 Trench Void Volume by Pressurization Tests .......... 31

3.3.3 Postgrouting Pressurization Tests $\ldots \ldots \ldots \ldots \ldots \ldots \ldots 36$

3.4 TRENCH GROUTING $\ldots \ldots \ldots \ldots \ldots \ldots \ldots \ldots \ldots \ldots \ldots$

3.5 GROUNDWATER MONITORING RESULTS $\ldots \ldots \ldots \ldots \ldots \ldots 45$

4. SUMMARY, CONCLUSIONS, AND NEEDS $\ldots \ldots \ldots \ldots \ldots \ldots \ldots 48$ 


\section{FOLLOW-UP STUDIES:}

GROUTING WITH CLAY-MICROFINE-CEMENT (CMFC) GROUTS 52

5.1 CMFC FORMULATION STUDIES $\ldots \ldots \ldots \ldots \ldots \ldots \ldots \ldots, 53$

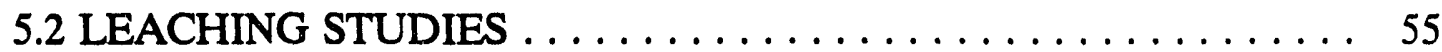

5.3 TRENCH GROUTING WITH A CMFC GROUT . . . . . . . . 59

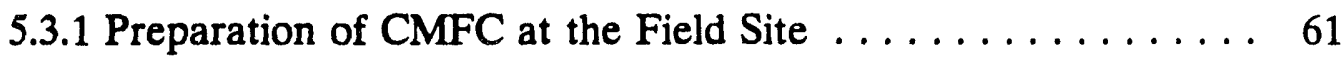

5.3.2 Trench Injection of CMFC $\ldots \ldots \ldots \ldots \ldots \ldots \ldots \ldots 61$

5.3.3 Field Testing of CMFC Grouted Trenches $\ldots \ldots \ldots \ldots 67$

6. SUMMARY AND CONCLUSIONS $\ldots \ldots \ldots \ldots \ldots \ldots \ldots \ldots \ldots$

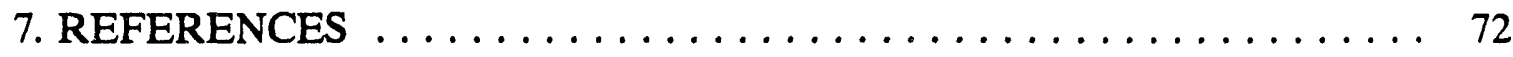

APPENDIX A

Soil penetration data after grouting with Portland Type I cement. . . . . . 75

APPENDIX B

Soil penetration data after grouting with CMFC $\ldots \ldots \ldots \ldots \ldots \ldots 77$

APPENDIX C

Soil penetration data from trench $148 \ldots \ldots \ldots \ldots \ldots \ldots \ldots \ldots .79$ 


\section{LIST OF FIGURES}

Figure

Page

1 Location and topography of burial trenches at the Test Area

for Remedial Actions in Solid Waste Storage Area Six. . . . . . . . . . . 2

2 Outline of waste trenches at the Test Area for

Remdial Action (TARA) site in Solid Waste Storage Area Six (SWSA6). 6

3 Locations of soil penetration tests

within and outside trenches 170 and $151 . \ldots \ldots \ldots \ldots \ldots$

4 Photograph of slotted pipe and installed injection well. . . . . . . 8

5 Reaching uniform pressure within trench using constant flow input. . . 13

6 Hydrograph of water elevations during the pump-in tests on

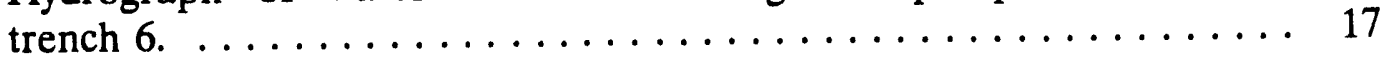

$7 \quad$ Hydrograph during water pump-in test on trenches 151 and $170 \ldots \ldots 18$

8 An effective or compressed hydrograph of water pump-in test at trenches 151 and $170 \ldots \ldots \ldots 19$

9 Grouting module used to inject grout in trenches 151 and $170 \ldots \ldots 23$

10 Summary of pregrouting scil penetration tests inside and outside trench area. ................. 27

11 Pregrout soil penetration results inside trench $170 . \ldots \ldots \ldots \ldots$

12 Pregrouting soil penetration results inside trench $151 \ldots \ldots \ldots \ldots$

13 Summary of soil penetration tests. $\ldots \ldots \ldots \ldots \ldots \ldots$

14 Location of trench wells used for pressurization tests. $\ldots \ldots \ldots \ldots$

15 Pressurization of trenches 151 and 170 at $40 \mathrm{cfm} . \ldots \ldots \ldots \ldots$

16 Pressurization of trenches 151 and 170 at $70 \mathrm{cfm} . \ldots \ldots \ldots \ldots$

17 Pressurization of trenches 151 and 170 at $100 \mathrm{cfm} . \ldots \ldots \ldots$ 
18 Pressurization of trenches 151 and 170 at $130 \mathrm{cfm} . \ldots \ldots \ldots \ldots$

19 Location of wells used for post-grouting pressurization tests. . . . . . 39

20 Pressurization of postgrouted trenches 151 and 170 at a flow rate of $110 \mathrm{cfm} . \ldots \ldots \ldots \ldots \ldots \ldots \ldots \ldots \ldots$

21 Pressurization of postgrouted trenches 151 and 170

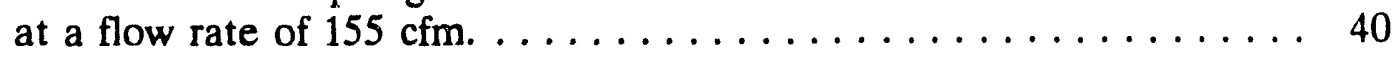

22 Pressure response in postgrouted trench 151 at a flow rate of $115 \mathrm{cfm} . \ldots \ldots \ldots \ldots \ldots \ldots \ldots \ldots \ldots$

23 Pressure response in post-grouted trench 170 at a flow rate of $105 \mathrm{cfm} . \ldots \ldots \ldots \ldots \ldots \ldots \ldots \ldots \ldots \ldots$

24 Leachability index of tritium as a function of time. . . . . . . . 58

25 Fraction of tritium leached from selected grout formulations as a function of time. . . . . . . 60

26 The $\mathrm{pH}$ of leachate generated from three grout formulations during the ANS-16.1 leaching test. . . . 60

27 Preparation of the grout formulation using a cyclonic mixer and grouting unit the field site. ........ 62

28 Location of wells used to inject grout into trench $148 \ldots \ldots \ldots \ldots 66$

29 Locations within trenches 148,151 , and 170 where hydraulic conductivity measurements were taken. . . . . . 68

30 Trench 148 soil penetration tests. . . . . . . . . . . . . . 69 


\section{LIST OF TABLES}

Table

Page

1 Depth of injection wells $\ldots \ldots \ldots \ldots \ldots \ldots \ldots$

2 Depth and length of screen in wells of post-grouted trenches $\ldots \ldots \ldots 10$

3 Void-volume measurements conducted using $\mathrm{CO}_{2}$ injection or $\mathrm{N}_{2}$ pressurization techniques $\ldots \ldots \ldots \ldots$

4 Summary of calculations of water-accessible void volumes derived from trench water pump-in tests $\ldots \ldots \ldots \ldots 16$

5 Chemical analyses typical of fly ashes and cements

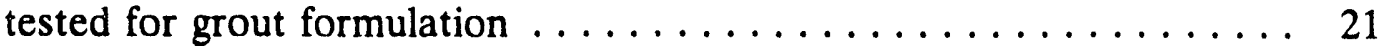

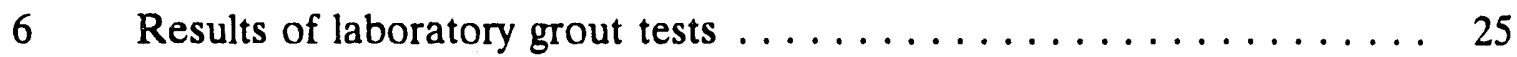

7 Grout formulation penetration-resistance results $\ldots \ldots \ldots \ldots$

8 Summary of pregrouting soil-penetration tests in trenches 151 and $170 \quad 29$

9 Preliminary pressurization data ${ }^{a} \ldots \ldots \ldots \ldots \ldots \ldots \ldots \ldots$

10 Pressurization constants and trench void volumes

for four inflow rates used in TARA trench pressurization tests $\ldots \ldots 33$

11 Trench pressures developed by injecting air into well $\mathrm{P}-16$ of trench $151 \ldots \ldots \ldots \ldots \ldots \ldots \ldots$

12 Trench pressures developed by injecting air into well P-2 of trench $170 \ldots \ldots \ldots \ldots \ldots$

13 Postgrouted trench void volumes estimated by the pressurization technique . . . . . . . . . . . 42

14 Operational description of grouting trench $170 \ldots \ldots \ldots \ldots \ldots$

15 Operational description of grouting trench $151 \ldots \ldots \ldots \ldots \ldots$

16 Radioactivity in water sampled

from wells $165-\mathrm{NW}$ and $165-\mathrm{SW}$ before and after grouting ....... 45 
17 Concentrations of metals $(\mathrm{mg} / \mathrm{L})$ in water $\ldots \ldots \ldots \ldots \ldots \ldots 47$

18 Estimated material costs for various grouting scenarios $\ldots \ldots \ldots \ldots 51$

19 Properties and composition of microfine cements $\ldots \ldots \ldots \ldots \ldots 52$

20 Fluidity of grout as influenced by chemicals added $\ldots \ldots \ldots \ldots, 54$

21 Fluidity and penetrability of grouts $\ldots \ldots \ldots \ldots \ldots \ldots \ldots$

22 Description of grouting formulations $\ldots \ldots \ldots \ldots \ldots \ldots \ldots \ldots$

23 Leachability indexes measured for three grout formulations . . . . . 59

24 Field grouting notes $\ldots \ldots \ldots \ldots \ldots \ldots \ldots \ldots \ldots \ldots \ldots$

25 Measurements of hydraulic conductivity within and adjacent to the trenches 


\begin{abstract}
In Situ Grouting of Low-Level Burial Trenches with a Cement-Based Grout at Oak Ridge National Laboratory. C. W. Francis, R. D. Spence, T. Tamura, and B. P. Spalding. ORNL/TM-11838, Oak Ridge National Laboratory, Oak Ridge, Tennessee.

A restoration technology being evaluated for use in the closure of one of the low-level radwaste burial grounds at Oak Ridge National Laboratory (ORNL) is trench stabilization using a cement-based grout. To demonstrate the applicability and effectiveness of this technology, two interconnecting trenches in Solid Waste Storage Area 6 (SWSA6) were selected as candidates for in situ grouting with a particulate grout. The trenches are $-15 \mathrm{ft}$ deep and measure 38 by $14 \mathrm{ft}$ and 47 by $14 \mathrm{ft}$. The primary objective was to demonstrate the increased trench stability and decreased potential for leachate migration following in situ injection of a particulate grout into the waste trenches. Stability against trench subsidence is a critical issue. For example, construction of impermeable covers over the trenches will be ineffective unless subsequent trench subsidence is permanently suspended.
\end{abstract}

Before the trenches were grouted, the primary characteristics relating to physical stability, hydraulic conductivity, and void volume of the trenches were determined. Before grouting, soil penetration tests revealed that at soil depths $>5$ and $<15 \mathrm{ft}$, mean blows per foot within the trench averaged $\sim 20$ blows per foot below that outside the trench, implying that considerable uncompacted soil and/or void space existed within the trench area which over time will lead to significant subsidence of the upper soil layers. Hydraulic conductivity tests within the trench area also revealed a high potential for the infiltration of water (hydraulic conductivities $>0.1 \mathrm{~cm} / \mathrm{s}$ ).

Void volume within the trenches was determined by two techniques: (1) water-pump tests and (2) a newly developed air-pressurization technique. Estimates of void volume using the air pressurization technique were $\sim$ twice that determined by the water-pump test $\left(230 \mathrm{yd}^{3}\right.$ vs $\left.115 \mathrm{yd}^{3}\right)$. The void volume determined by the water pump test most likely represents the void volume that could be realistically filled by grout. Also, this test contained a correction for the quantity of water observed in adajent trenches whereas the pressurization tests did not involve measurements of pressures in the adjacent trenches. The development of the air pressurization technique was pursued because water-pump testing may result in serious leaching of radionuclides and/or hazardous wastes into groundwater and induce premature settling of soil overburden into the trench.

After grouting, soil-penetration tests disclosed that stability had been improved greatly. For example, refusal (defined as $>100$ blows to penetrate to a depth of $1 \mathrm{ft}$ ) was encountered in 17 of the 22 tests conducted within the trench area. Mean refusal 
depths for two trenches were 11.5 and $8.5 \mathrm{ft}$, respectively. The postgrout soil-penetration tests revealed that the stability of the trench was significantly better than pregrout conditions, and at depths $>8 \mathrm{ft}$, the stability was very near that observed in the native soil formation outside the trench. The major differences in results between postgrouting tests and tests conducted in native soil formations outside the trench were found at soil depths of 6,7 , and $8 \mathrm{ft}$. Tests within the trench showed lower stability within this range proluably because of the presence of intermediate-size soil voids (formed during backfilling) that were too small to be penetrated and filled by the conventional cement grout formulation. Hydraulic conductivity within the trench remained very high $(>0.1 \mathrm{~cm} / \mathrm{s})$ and significantly higher than outside the trench. Postgrouting air-pressurization tests also revealed a large degree of intervoid linkage within and between the two trenches. Thus, it appears that to effectively reduce hydraulic conductivity and to develop stability within the upper level of the trench it may be necessary to implement additional stabilization techniques. One possibility is the injection of a chemical or microfine cement grout into the upper level of the grouted trench.

In follow-up studies conducted during the summer of 1991, the same two trenches previously grouted with the Portland Type I cement-based grout, were grouted again with another particulate-based grout made from a microfine cement (a fine grained cement $>50 \%$ by weight to be $<5 \mu \mathrm{m}$ diam) and Wyoming bentonite to fill the unfilled void spaces and reduce hydraulic conductivity within these trenches. The same clay-microfine-cement (CMFC) grout was also injected into a another trench.

Approximately $12 \mathrm{yd}^{3}$ of the CMFC was injected into the previously grouted trenches with the expressed purpose of lowering hydraulic conductivity within these trenches. Measurements of hydraulic conductivity after grouting with ihe CMFC grout averaged $1.2 \times 10^{-3} \mathrm{~cm} / \mathrm{s}$, considerably higher than average hydraulic conductivity in soil outside the trenches $\left(6.4 \times 10^{.5} \mathrm{~cm} / \mathrm{s}\right)$. Thus, these data indicate grouting with the clay-microfine cement did not reduce hydraulic conductivity to levels commonly observed in surrounding soils. The average hydraulic conductivity measured in the CMFC grouted trench was approximately the same as that measured in the grouted 151 and 170 trenches $\left(1.7 \times 10^{-3} \mathrm{~cm} / \mathrm{s}\right)$ and much higher than the average measured in the surrounding soils, again indicating grouting with the CMFC grout did not appreciably lower hydraulic conductivity measurements in the trench. In addition, trench stability was not increased using the CMFC grout. For example, soil-penetration data before and after grouting with the CMFC grout revealed no significant difference $(\mathrm{P}<0.5)$ in the number of blows to penetrate the distance of one foot indicating no benefits in increased trench stability from the CMFC grout.

These in-situ grouting studies of low-level burial trenches with cement-based grouts (using Portland Type I cement) have shown considerable benefit in increasing trench stability against potential future subsistence; however, little effect can be 
expected with regard to lowering hydraulic conductivity within the trenches, even if clay-based microfine cements are used ás grouting materials. 


\section{INTRODUCTION}

Oak Ridge National Laboratory (ORNL) has recently finished placing an interim covering $\sim 10$ acres of Solid Waste Storage Area 6 (SWSA 6), where low-level radioactive wastes (LLRW) have been buried in shallow trenches (Bechtel 1988; Lockwood Greene 1988). The final closure of SWSA 6 awaits the completion of its remedial investigation into the nature and extent of contamination as well as the development of effective and safe techniques to stabilize the burial trenches. To select trench stabilization and closure alternatives, a group of 19 burial trenches in SWSA 6 was identified as a demonstration and test area to (1) identify promising trench stabilization and closure techniques applicable to the ORNL setting, (2) carry out these techniques on a field scale in actual LLRW trenches, and (3) collect the necessary data to evaluate each technique relative to its feasibility, effectiveness, and cost.

This project, called Test Area for Remedial Actions (TARA), is being conducted on a small hillock in the northeastern corner of SWSA 6 (Spalding et al. 1989, see Fig. 1). The site was selected primarily on the basis of the following two criteria: (1) it is away from daily waste management activities and most important (2) it is located entirely on high ground and is isolated hydrologically from any peripheral recharge areas tiat would complicate formulating a site water budget and conducting performance monitoring as part of the stabilization/closure evaluations. The water table at the site is at least $20 \mathrm{ft}$ below the bottoms of the trenches, and the trenches in the area are, therefore, unsaturated throughout the majority of the year in contrast to being chronically seasonally inundated, as is the case with other trench areas within SWSA 6.

Two stabilization and closure technologies have been demonstrated at this site. Five burial trenches have undergone a dynamic compaction demonstration (Spalding et al. 1989), and two have been grouted by the in situ injection of a polyacrylamide chemical grout (B. P. Spalding and Fontaine 1992). Dynamic compaction is quite effective in improving the stability of SWSA 6 burial trenches (Spalding 1986), and in situ grouting with polyacrylamide significantly reduces the iydrologic conductivity within the trench (Spalding et al. 1987). Final closure requires sufficient stability within the trench area to ensure that subsidence will not occur after construction of trench caps and moisture barrier controls. Dynamic compaction appears to be a relatively inexpensive stabilization approach. On the other hand, in situ grouting of uncompacted trenches with polyacrylamide appears to be expensive because of the cost of the acrylamide grouting materials ( $\$ 2 / \mathrm{gal}$ ) and relatively large volume voids of uncompacted trenches (estimated cost is $\sim \$ 50,000$ per typical burial trench). However, if the two are combined (i.e., dynamic compaction followed by in situ grouting with acrylamide), the costs involved would be much less because $-80 \%$ of the trench void volume is reduced by dynamic compaction. Demonstration tests conducted during September and October of 1989 revealed that the low hydrologic conductivity of compacted trenches limited the mobility of the acrylamide monomer and its setting catalysis to such an extent that in situ grouting 


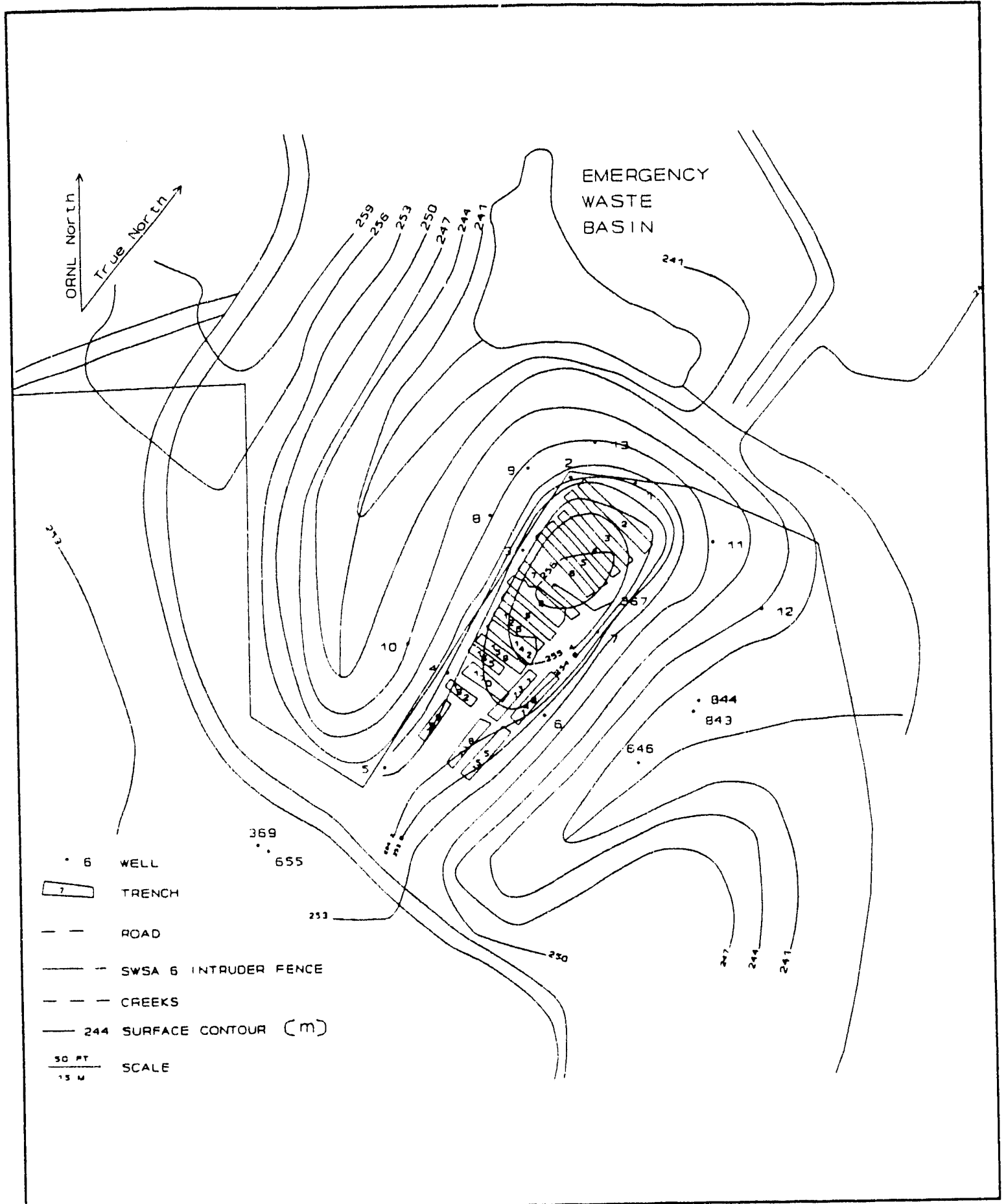

Fig. 1. Location and topography of burial trenches at the Test Area for Remedial Actions in Solid Waste Storage Area 6. 
of compacted trenches was not possible (B. P. Spalding, ESD, ORNL, personal communication to B. P. Spalding, FSD, ORNL, November 1989).

Implementation of either stabilization technology-dynamic compaction or in situ grouting with acrylamide-may also present serious environmental and safety consequences. Of most concern is the improper use of acrylamide, a toxic substance and suspected carcinogen. It poses a risk to those who prepare and inject the grout; also if conditions exist in the trench that inhibit polymerization, it might contaminate groundwater used for drinking and there by pose a potential health hazard. After acrylamide polymerizes (viz, after the grout sets), it becomes nontoxic and nonhazardous. Hence, the ability to control the polymerization process (i.e., set time) after injection into the burial trenches is paramount in order to ensure that the process will not result in groundwater contamination. In many cases, considerable testing may be required to make certain that set time is not adversely affected by the inorganic and/or organic constituents contained in the waste trenches. These assurances will probably have to be demonstrated and documented before federal and state regulatory agencies grant the approval to implement.

Dynamic compaction on trenches in SWSA 6 also presents some unique safety and environmental concerns. For example, resuspension of contaminated soil presents a potential risk with respect to the inhalation, ingestion, and absorption of radionuclides or toxic chemicals by site personnel. Even though previous demonstrations have shown this is not a significant concern, precautions and rigid safety rules need to be followed when the technique is used. Because some of the burial trenches in SWSA 6 hold incidental but unquantified amounts of contained liquids, some of which may be toxic and hazardous, the environmental impact on groundwater as these liquids are released during the dynamic compaction process is inherently unpredictable. Also, many of the trenches in SWSA 6 are inundated with groundwater either seasonally or chronically (Solomon et al. 1988). Thus, many of the trenches will have to be dewatered, and the influence of dynamic compaction needs to be determined on these trenches containing soil backfill near field saturation. The chief issue at hand is the ability to demonstrate the recovery of liquid released during compaction.

Because of the (1) high costs associated with in situ grouting of acrylamide in uncompacted trenches, (2) the inability to use the acrylamide in situ grouting technique at dynamically compacted trenches, and (3) the unresolved questions relating to the release of contained liquids during dynamic compaction of burial trenches, the U.S. Department of Energy (DOE) has asked ORNL to demonstrate if in situ grouting with a particulate-based grout is a viable alternative that will provide long-term burial trench stability (Tom Wheeler, DOE Oak Ridge Operations Manager for the ORNL Environmental Restoration Program personal communication to Ken Cook, program manager for ORNL Remedial Action Program, July 25, 1989).

ORNL has previously conducted demonstrations using particulate grout in waste 
trenches (Tamura et al. 1987; Davis and Spalding 1986). Davis and Spalding (1986) used a particulate grout (cement-bentonite) to grout an opened (new) trench and compared its effectiveness in isolating waste hydrologically with that of Hypalon (a reinforced chlorosulfonated polyethylene fabric). The researchers concluded that the cement-bentonite grouting treatment offered a higher degree of waste isolation than did the lining technique. Tamura et al. (1987) injected a particulate type grout made of cement, fly ash, and bentonite into a LLRW trench in SWSA 6. The demonstration revealed that a cement-based grout could be successfully formulated and pressure-injected into a SWSA 6 waste trench. Thirty-six injection wells (2-in.-diam lances made of Schedule 80 steel pipe) were installed at 5-ft centers in a trench measuring $56 \mathrm{ft}$ long, $9 \mathrm{ft}$ wide, and $12 \mathrm{ft}$ deep. Five of the injection wells took $78 \%$ of the grout injected, which indicated that grout mobility within the trench was not greatly restricted. The average pumping rate was $6.1 \mathrm{gpm}$ at a pressure range of 5 to 10 psi. The total volume of grout injected was $8081 \mathrm{gal}$ ( $\sim 9 \%$ more than the measured void volume). Void volume within the trench was estimated to have been reduced three orders of magnitude; however, pumping tests with water revealed significant movement of water between injection wells within individual areas of the trench. Postgrouting penetration test results were conducted but were compared with those of penetration tests conducted on an adjacent ungrouted waste trench rather than on the pregrouted waste trench. These tests revealed the denser nature of the grouted trench compared with bordering ungrouted trench.

To validate this observation, the present demonstration involving the grouting of a SWSA 6 trench with particulate grout has been conducted. In this demonstration, penetration tests were conducted within the trench area before as well as after grouting. The primary objective of this task is to demonstrate the feasibility and effectiveness of the in situ injection of a particulate grout into waste burial trenches. Effectiveness is defined here as increased trench stability (characterized by soil-penetration tests) and decreased potential for leachate migration (characterized by hydraulic conductivity tests). 


\section{METHODS AND MATERIALS}

\subsection{SITE DESCRIPTION}

Two trenches, Nos. 151 and 170 in the TARA site (Fig. 2), were selected as candidates for in situ grouting with a particulate grout. The locations of both of these trenches have been surveyed and the corners of each marked. Each of the trenches are $\sim 15 \mathrm{ft}$ deep. Trench 151 measures 42 by $14 \mathrm{ft}\left(\sim 583 \mathrm{ft}^{2}\right)$ and trench 170 measures 44 by $14 \mathrm{ft}\left(\sim 612 \mathrm{ft}^{2}\right)$. The two trenches are interconnected; the south end of trench 170 overlaps into the north side of trench 151 (see Fig. 2). These trenches were selected for grouting for two reasons:

1. The void volume of each has been determined by filling with water, and there have been limilid measurements of soil penetration within and adjaceni the trenches.

2. The water table is $\sim 20$ to $30 \mathrm{ft}$ below the bottoms of the trench and thus the trenches are unsaturated throughout most of the year, except possibly after an extended heavy rain in which case water may accumulate for a short time in the bottom of the trenches.

\subsection{SOILPENETRATION TESTS}

A nonstandard penetration test has been developed for use over trenches to avoid auguring contaminated waste to the surface as would result if the standard ASTM (D 1586-84) soil-penetration test were used. The nonstandard test uses a 140-lb drill-rig-mounted drop hammer to drive a 2 -in.-diam $60^{\circ}$ cone point attached to a 1.75-in.-diam drill rod into the ground. The drill rod is marked at 1- $\mathrm{ft}$ lengths, and penetration is measured by the number of blows required to move the device $1 \mathrm{ft}$ into the ground. In January 1990, 12 penetration tests were conducted in trench 170, and ten tests were conducted in trench 151 (Fig. 3). Holes from the penetration test were used to insert casings which in turn were used both to conduct pregrouting hydraulic conductivity tests and to serve as injection wells for pumping grout into the trench. In addition to those penetration tests within trenches 170 and 151 , penetration tests were conducted outside the perimeter of the two trenches (see Fig. 3).

\subsection{INSTALLATION OF INJECTION WELLS}

The previous particulate grouting demonstration (Tamura et al. 1987) used lances made of 2-in.-diam Schedule 80 steel pipe as injection wells. These were placed at $\sim 5$-ft centers over the surface of the trench (total of 36 injection wells). The lances 


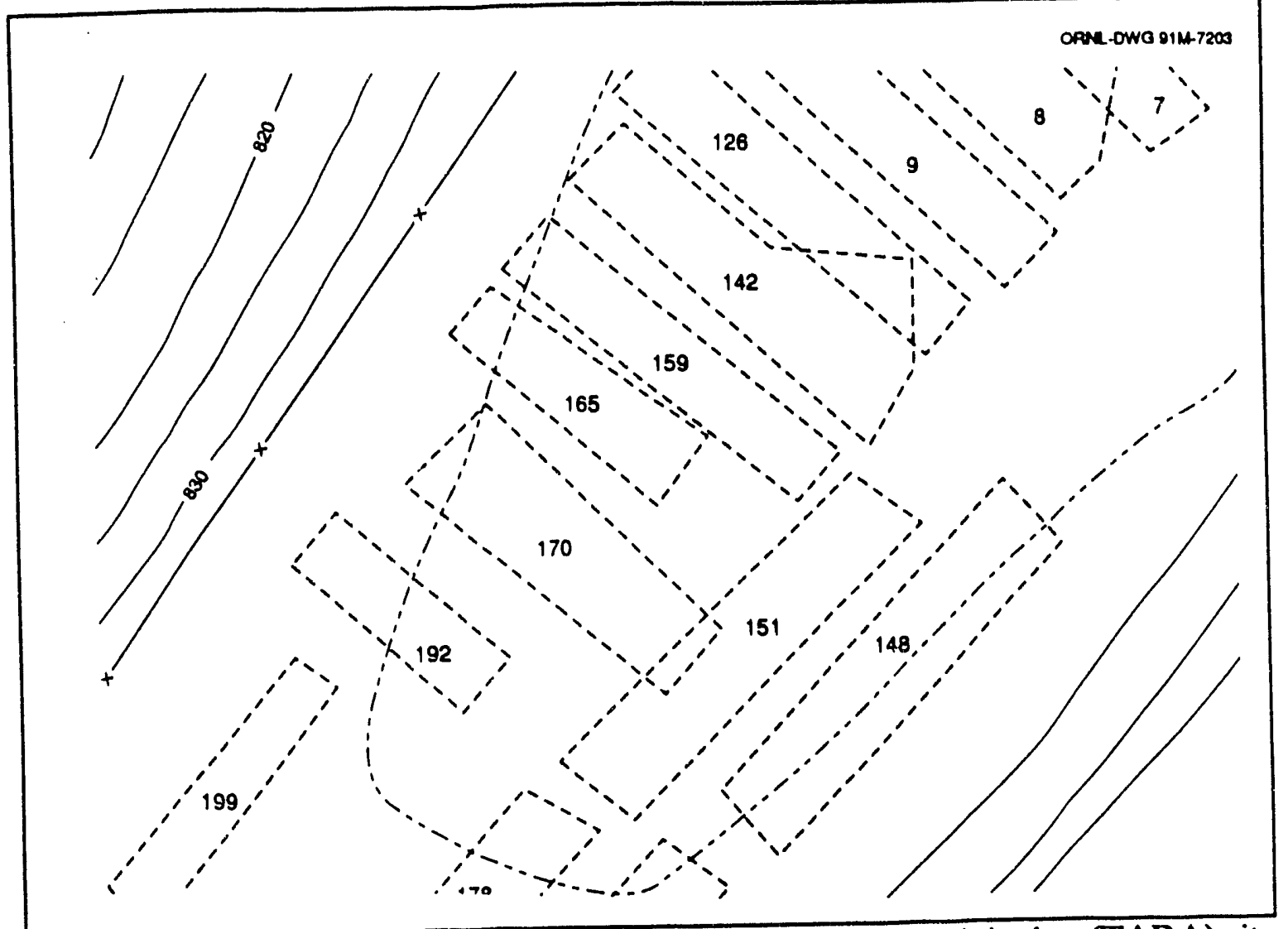

Fig. 2. Outline of waste trenches at the Test Area for Remdial Action (TARA) site in Solid Waste Storage Area Six (SWSA6).

were driven by a 120-1b portable air-driven hammer either to the bottom of the trench or until an obstruction was encountered. Once in place, the lance was pulled up 6 in. and the drive point knocked out of the end for grout injection. When pressures $>20$ psi or flow rates $<6 \mathrm{gal} / \mathrm{min}$ were encountered, the lance was then pulled up another 6 in. for additional grout injection. Five injection wells accounted for $\sim 80 \%$ of the grout injected, and it was recommended that future demonstrations use fewer injection wells (e.g. , injection wells should be based on 20 - to 25 -ft centers rather than on the 5 -ft center that was used). It was also recommended that smaller-diameter pipe be used because of the difficulty in reaching the bottom of the trench. For example, in most instances the lances could not be driven as much as $7 \mathrm{ft}$. The trench bottom was reached in only 4 out of the 36 injection wells installed.

Several other operational problems were also encountered. For example, because of the 5-ft centers, grout was often pumped directly into one well and out an adjacent well. The poor seal between the lance and surface soil (as a result of moving the lance upward in 6-in. increments during grout injection) often resulted in the breakthrough of grout around the injection wells, even at a relatively low grout injection pressure of 15 


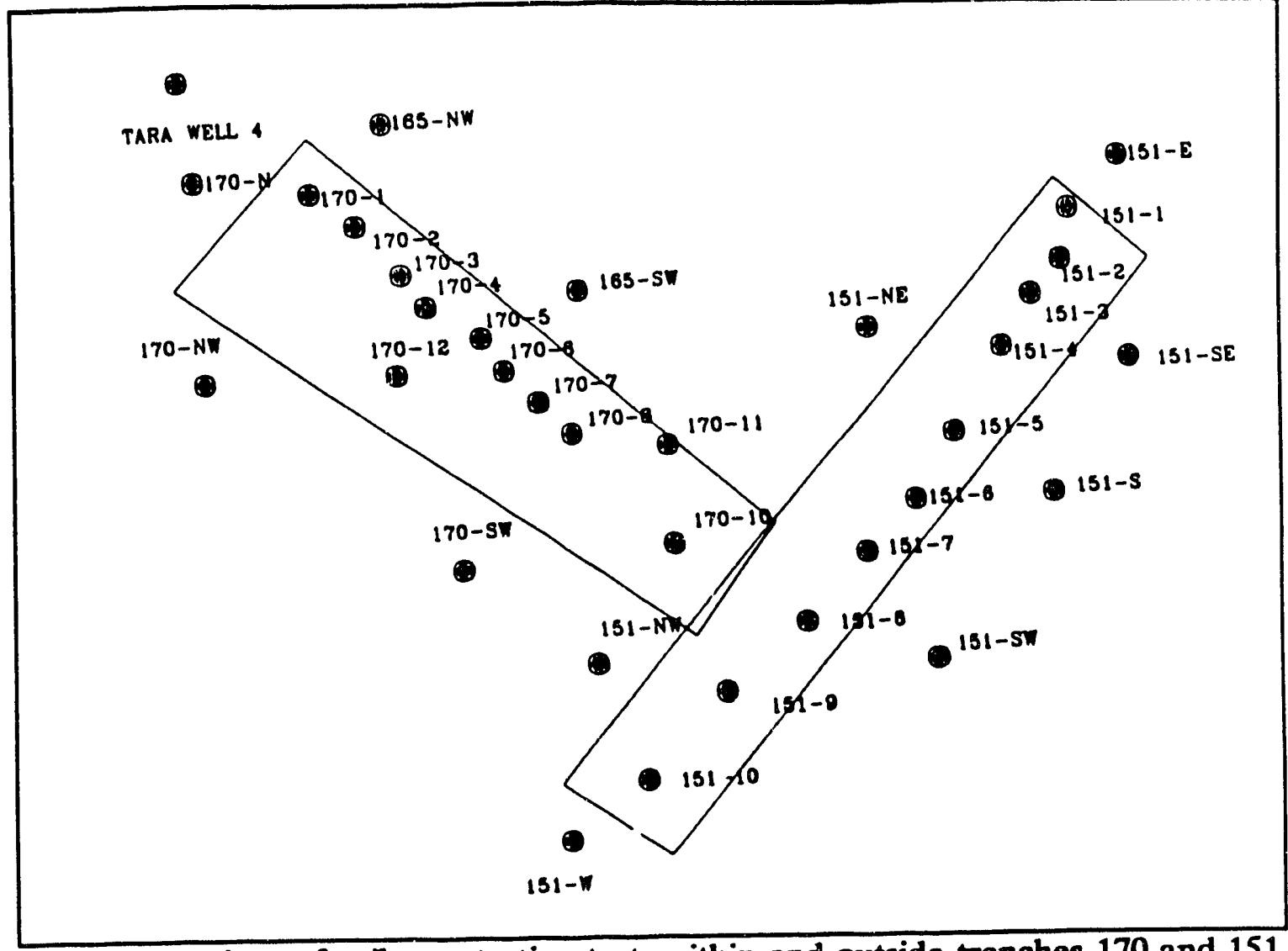

Fig. 3. Locations of soil penetration tests within and outside trenches 170 and 151 .

to $20 \mathrm{psi}$.

Several changes were made in the installation of injection wells for this demonstration. The major changes included the use of (1) slotted pipe as injection wells and (2) considerably fewer injection wells [10 to 12 per trench compared with the 36 in the Tamura et al. (1987) study]. Slotted polyvinylchloride (PVC) pipe (threaded and flush-jointed, Schedule 80, 1.25-in. diam) constructed with three rows of 0.1-in.-wide slots (42 slots/ft-row, effective filter area of $11.5 \mathrm{in}^{2} / \mathrm{ft}$ ) were placed into the holes made during the penetration tests. Solid sections of similar pipe were installed to at least $2 \mathrm{ft}$ below the soil surface. These pipe were obtained from Timco Manufacturing, Inc., Prairie du Sac, Wisconsin. To ensure that injected grout did not retum to the surface along the pipe/soil interphase, a 1-ft section of 2-in.-diam pipe was placed over the 1.25-in.-diam pipe and driven into the ground to -3 in. below the soil surface. A cement-based grout collar was then molded around the surface of the pipe/soil interphase (see Fig. 4).

Several holes made during penetration tests could not be used as injection wells because the drill rods were contaminated to the extent that they were unsafe for handling; 
thus, in these cases the drill rods were abandoned in the hole. This was the situation for penetration tests 4,5 , and 9 in trench 170 , resulting in only nine wells for trench 170 and ten wells for trench 151 (Table 1). In most cases, the injection wells reached to the bottom of the trench (Table 1). The technique was certainly better in this respect than the technique used by Tamura et al. (1987) in which only 4 of the 36 injection wells reached to the bottom of the trench.

\subsection{HYDRAULIC CONDUCTIVITY MEASUREMENTS}

\subsubsection{Pregrouted Trenches}

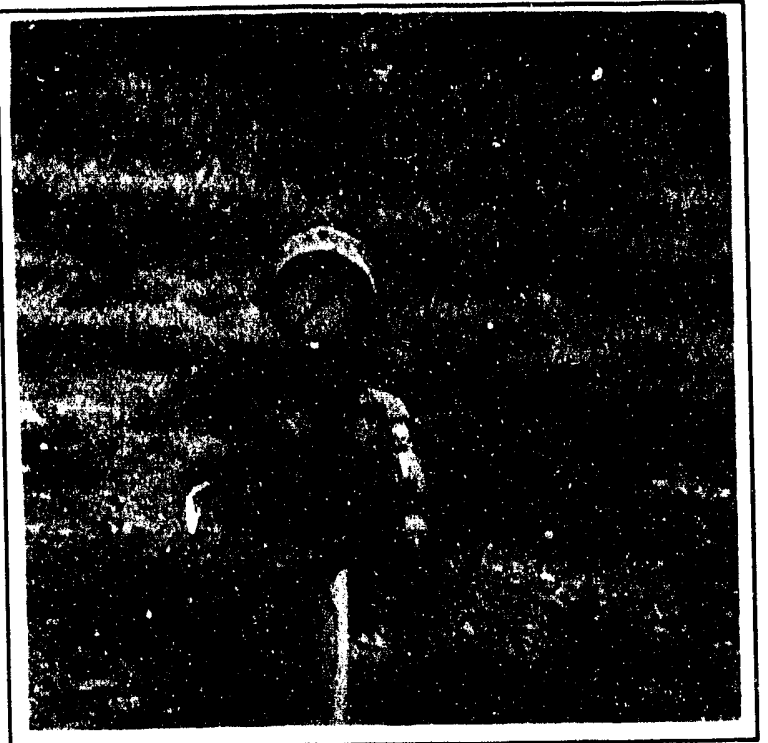

Fig. 4. Photograph of slotted pipe and installed injection well (ORNL 7371-90).

Hydraulic conductivity of pregrouted trenches was estimated. This was accomplished by pouring $6 \mathrm{~L}$ aliquots of water into the slotted injection wells. This technique was chosen because the ORNL Office of Environmental Compliance and Documentation prohibited the use of a constant head pump-test as demonstrated by Spalding et al. (1985). The use of such a technique in the highly permeable pregrouted trenches would require considerable water; thus, the leaching of contaminants from the trench area would be promoted. Also, Spalding et al. (1985) have collected considerable data demonstrating that the hydraulic conductivity of ungrouted trenches average on the order of $1.5 \times 10^{-2} \mathrm{~cm} / \mathrm{s}$.

The tests were conducted in the following manner. First, assume no greater than $13 \mathrm{ft}$ of slotted pipe per injection well (conservative assumption based

Table 1. Depth of injection wells

\begin{tabular}{cccccc}
\hline \multicolumn{2}{c}{ Trench 151 } & \multicolumn{2}{c}{ Trench 170 } & \multicolumn{2}{c}{ Outside Trenches } \\
Well No. & A & Well No. & f & Well No. & $\mathrm{ft}$ \\
\hline $151-1$ & 15 & $170-1$ & 15 & $151-\mathrm{E}$ & 12 \\
$151-2$ & 13 & $170-2$ & 15 & $151-\mathrm{NE}$ & 13 \\
$151-3$ & 15 & $170-3$ & 15 & $151-\mathrm{NW}$ & 15 \\
$151-4$ & 8 & $170-6$ & 15 & $151-\mathrm{S}$ & 7 \\
$151-5$ & 15 & $170-7$ & 15 & $151-\mathrm{SE}$ & 7 \\
$151-6$ & 11 & $170-8$ & 15 & $151-\mathrm{SW}$ & 15 \\
$151-7$ & 13 & $170-10$ & 12 & $151-\mathrm{W}$ & 10 \\
$151-8$ & 14 & $170-11$ & 12 & $170-\mathrm{N}$ & 15 \\
$151-9$ & 14 & $170-12$ & 15 & $170-\mathrm{NW}$ & 15 \\
$151-10$ & 15 & & & $170-\mathrm{SW}$ & 5 \\
Mean & 13.3 & Mean & 14.1 & Mean & 11.4 \\
\hline \hline
\end{tabular}


on well depths listed in Table 1). The area available for entry into the trench for such an injection well would be $-982 \mathrm{~cm}^{2}$ (filter area for the 1.25 -in.-diam pipe is $74 \mathrm{~cm}^{2} / \mathrm{ft}$ ). At a hydraulic conductivity of $0.1 \mathrm{~cm} / \mathrm{s}$, at least $100 \mathrm{~mL}$ would have to pass into the trench area within $1 \mathrm{~s}$. The volume potentially contained in a 15 - $\mathrm{ft}$ injection well (assuming complete closure) would be $3.62 \mathrm{~L}$. Thus, if it were demonstrated that the well could take $6 \mathrm{~L}$ of water over a 23-s period (the maximum flow rate of $6 \mathrm{~L}$ of water through the funnel used to deliver water to the injection well), the hydraulic conductivity of the pregrouted trench would be $>0.1 \mathrm{~cm} / \mathrm{s}$. Three wells from each of the two trenches were randomly selected and $6 \mathrm{~L}$ of water poured into them over a 23-s period. In no case were the well casings filled to overflowing, indicating that the hydraulic conductivity of pregrouted trenches was $>0.1 \mathrm{~cm} / \mathrm{s}(-0.8 \mathrm{~cm} / \mathrm{s}$, assuming $2.8 \mathrm{~L}$ is delivered across a filter area of $982 \mathrm{~cm}^{2}$ in $23 \mathrm{~s}$ ).

\subsubsection{Postgrouted Trenches}

Wells for measuring hydraulic conductivity within the trench area following grouting were installed using the holes made during the postgrouting penetration tests. A total of 22 wells (12 in trench 151 and 10 in trench 170) were installed. Instead of using the 0.1 -in.-wide slotted pipe (as in the pregrout injection wells), 0.02-in.-wide slotted pipes were installed (1.25 in. ID, Schedule 80 PVC, see Table 2 ). The effective filter area for this pipe is $21 \mathrm{~cm}^{2} / \mathrm{ft}$.

Water was poured into nine of these wells (P-2, P-3, P-4, P-7, P-11, P-17, P-18, $\mathrm{P}-22$, and $\mathrm{P}-24)$ to estimate lower limits in hydraulic conductivity and to compare the hydraulic conductivity within the postgrouted trench with that outside the trench. These tests were conducted in a manner similar to those for pregrouted trenches (i.e., $6 \mathrm{~L}$ were delivered through a flow cone over a 23-s interval). Only one well failed to take the full $6 \mathrm{~L}$ (well P-2, which overflowed after $6 \mathrm{~s}$ ). On the other hand, two wells outside the trench area (well P-1, which was $15 \mathrm{ft}$ deep with $12 \mathrm{ft}$ of 0.02 -in.-wide screen, and well $151-\mathrm{W}$, a pregrout monitoring well at the west end of trench 151) failed to take $6 \mathrm{~L}$ of water in the $23 \mathrm{~s}$ which indicates that the hydraulic conductivity within the trench area after grouting was generally $>0.1 \mathrm{~cm} / \mathrm{s}$ and appreciably greater than that measured in undisturbed soil outside the trench. For example, mean hydraulic conductivity of undisturbed soil formation at the TARA site in "driven" wells was $1.2 \times 10^{-5} \mathrm{~cm} / \mathrm{s}$. Previous measurements in SWSA 6 have resulted in mean hydraulic conductivities of $3.5 \times 10^{-5}$ and $2.0 \times 10^{-5} \mathrm{~cm} / \mathrm{s}$, Luxmoore et al. (1981) and Davis et al. (1984), respectively.

\subsection{VOID-VOLUME MEASUREMENTS}

The combined void volume of trenches 151 and 170 has previously been determined by filling with water and taking into account losses resulting from seepage 
10

Table 2. Depth and length of screen in wells of post-grouted trenches

\begin{tabular}{lccccc}
\hline & \multicolumn{2}{c}{ Trench 151 } & & \multicolumn{3}{c}{$\begin{array}{c}\text { Trench 170 } \\
\text { Well }\end{array}$} & $\begin{array}{c}\text { Depth } \\
\mathrm{ft}\end{array}$ & $\begin{array}{c}\text { Screen } \\
\mathrm{ft}\end{array}$ & $\begin{array}{c}\text { Well } \\
\text { No. }\end{array}$ & $\begin{array}{c}\text { Depth } \\
\mathrm{ft}\end{array}$ & $\begin{array}{c}\text { Screen } \\
\mathrm{ft}\end{array}$ \\
\hline P-14 & 14.5 & 10 & P-2 & 15 & 12 \\
P-15 & 11.5 & 9 & P-3 & 15 & 12 \\
P-16 & 14.8 & 12 & P-4 & 9.2 & 5 \\
P-17 & 7.6 & 5 & P-5 & 5.5 & 2 \\
P-18 & 8.9 & 6 & P-6 & 8.2 & 5 \\
P-19 & 8.3 & 6 & P-7 & 7.7 & 4 \\
P-20 & 11.3 & 7 & P-8 & 9.3 & 7 \\
P-21 & 12.7 & 9 & P-9 & 7.9 & 5 \\
P-22 & 11.3 & 7 & P-10 & 10.4 & 7 \\
P-23 & 15 & 7 & P-11 & 10.2 & 7 \\
P-24 & 13.8 & 7 & & & \\
P-25 & 15 & 7 & & & \\
\hline \hline
\end{tabular}

into the surrounding soil (see description of water pump-in test in Sect. 2.5.3). This practice may result in serious leaching of radionuclides and/or hazardous wastes into groundwater and induce premature settling of soil overburden into the trench. It also leaves soil within the trench near saturation levels for a significant period of time, which could have an effect on solidification of grout introduced into the trench. Consequently, flooding trenches with water is no longer an acceptable practice for determining trench void volume. Thus, an alternative nondestructive method was needed for determining trench void volume.

A potential nondestructive method for determining trench void volume is based on pressurization of the trench (treating it like a closed but leaky vessel) and calculation of void volume from the ideal gas law. This is the same technique used in the $\mathrm{N}_{2}$ pressurization of the closed radwaste disposal silo in SWSA 6 (Table 3); however, in this case ambient air (instead of $\mathrm{N}_{2}$ ) was pumped into the trench. The trench is obviously not a closed vessel, but experience during grouting exercises has revealed that pressures of $\sim 10$ to $15 \mathrm{psi}$ can be achieved. After taking into consideration leak rates (similar to those used in determining trench void volume by flooding with water), void volume can 
Table 3. Void-volume measurements conducted using $\mathrm{CO}_{2}$ injection or $\mathrm{N}_{2}$ pressurization techniques

\begin{tabular}{ccc}
\hline Technique & $\begin{array}{c}\mathrm{CO}_{2} \text { or } \mathrm{N}_{2} \text { influx } \\
\left(\mathrm{ft}^{3} / \mathrm{min}\right)\end{array}$ & $\begin{array}{c}\text { Estimated } \\
\text { void volume } \\
\left(\mathrm{yd}^{3}\right)\end{array}$ \\
\hline $\mathrm{CO}_{2}$ injection & $0.35-0.43$ & $13.5-16.2$ \\
& $1.02-1.12$ & $13.6-15.1$ \\
& $1.70-1.79$ & $14.5-15.2$ \\
$\mathrm{~N}_{2}$ pressurization & 0.51 & 14.3 \\
& 0.80 & 14.8 \\
& 0.89 & 17.4 \\
& 1.10 & 17.3 \\
\hline
\end{tabular}

${ }^{a}$ Void volume measured in the Solid Waste Storage Area Six (SWSA 6) below-grade radwaste disposal silo, September 1989, by P. J. Hanson and C. W. Francis.

be calculated from the ideal gas law. Validation of such a simple technique to determine trench void volume would be a significant accomplishment. For example, one of the most important criterion in determining the effectiveness of in situ grouting is the extent to which the available void space is filled with grout. To do this, it is imperative that the total void volume of the trench be known. Trenches 151 and 170 were selected for grouting because trench volumes had previously been determined by flooding with water, a technique that can no longer be practiced. Thus, these trenches offered an opportunity to verify the use of alternative methods to determine trench void volume.

\subsubsection{Trench Pressurization-Theory}

This technique is based on the principle that small pressure differentials ( $<0.5$ psi) can be monitored within the trench as a known rate of gas is pumped into the trench. The technique assumes that the void volume of the trench remains constant and that air leaking from the trench occurs across a constant resistance to air flow. The measurement is based on the ideal gas law, where equation (1) describes conditions in the trench before pressurization, and equation (2) describes conditions in the trench after pressurization to a constant pressure, and 


$$
\begin{gathered}
V_{0}=\frac{n_{o} R T}{P_{0}} \\
V_{0}=\frac{n_{d} R T}{P_{c}}
\end{gathered}
$$

$V_{0}=$ void volume of trench,

$n_{0}=$ moles of gases initially present in trench,

$R=$ ideal gas constant,

$T=$ ambient absolute temperature in trench,

$P_{0}=$ pressure initially present in trench (assumed $1 \mathrm{~atm}$ ),

$P_{c}=$ pressure in trench after pressurization to constant pressure, and

$n_{x}=n_{0}+n_{1}$

$=$ moles of gases after pressurization, where $n_{0}$ is equal to the moles of gas initially present and $n_{1}$ is equal to the net moles of gases added to cause increased pressure to $P_{c}$.

Thus, the volume of gas added $\left(V_{l}\right)$ to result in $P_{c}$ is equal to

$$
V_{1}=\frac{n_{1} R T}{P_{c}}
$$

Combining Eqs. (1) and (2) and assuming no difference in temperature on pressurization,

$$
n_{o}=\frac{n_{1} P_{o}}{P_{c}-P_{o}}
$$

and substituting Eqs. (1) and (3), respectively for $n_{o}$ and $n_{l}$ results in

$$
V_{o}=\frac{V_{1} P_{c}}{P_{c}-P_{o}}
$$

The volume attributed to the pressure change in the trench $\left(V_{l}\right)$ can be determined by monitoring the pressure increase in the trench (gage pressure in trench, $P_{t g}$ ) over the time it takes to develop a constant gage pressure $\left(P_{c g}\right)$ from a constant flow rate of air pumped into the trench (Fig. 5). When the trench is at constant pressure, the outflow (leak rate) is equal to the inflow rate. To illustrate, the pressure in the trench can be expressed mathematically

$$
P_{18}=P_{c g}\left(1-e^{\left.-B_{1}\right)}\right)
$$


where

$P_{18}=$ the gage pressure in the trench at time (t),

$P_{c g}=$ the constant gage pressure in trench after $\infty$ time at constant inflow,

$B_{1}=$ a constant descriptive of the pressure rise in the trench.

If one assumes the outflow rate $\left(F_{o}\right)$ is proportional to pressure differential over time,

$$
F_{0}=F_{c}\left(1-e^{-B_{1}}\right)
$$

where

then

$$
F_{c}=\text { constant pump rate into trench, }
$$

$$
F_{0}=\frac{P_{l g}}{P_{c z}} x F_{c}
$$

from which one can calculate the outflow rate as a function of time. In this case, the outflow rate takes the same form as the pressure change in the trench. From conservation of mass, at any specific time the net flow rate that remains in the trench $(F)$ is equal to the flow into the trench $\left(F_{c}\right)$ minus the flow rate out of the trench $\left(F_{o}\right)$. Thus

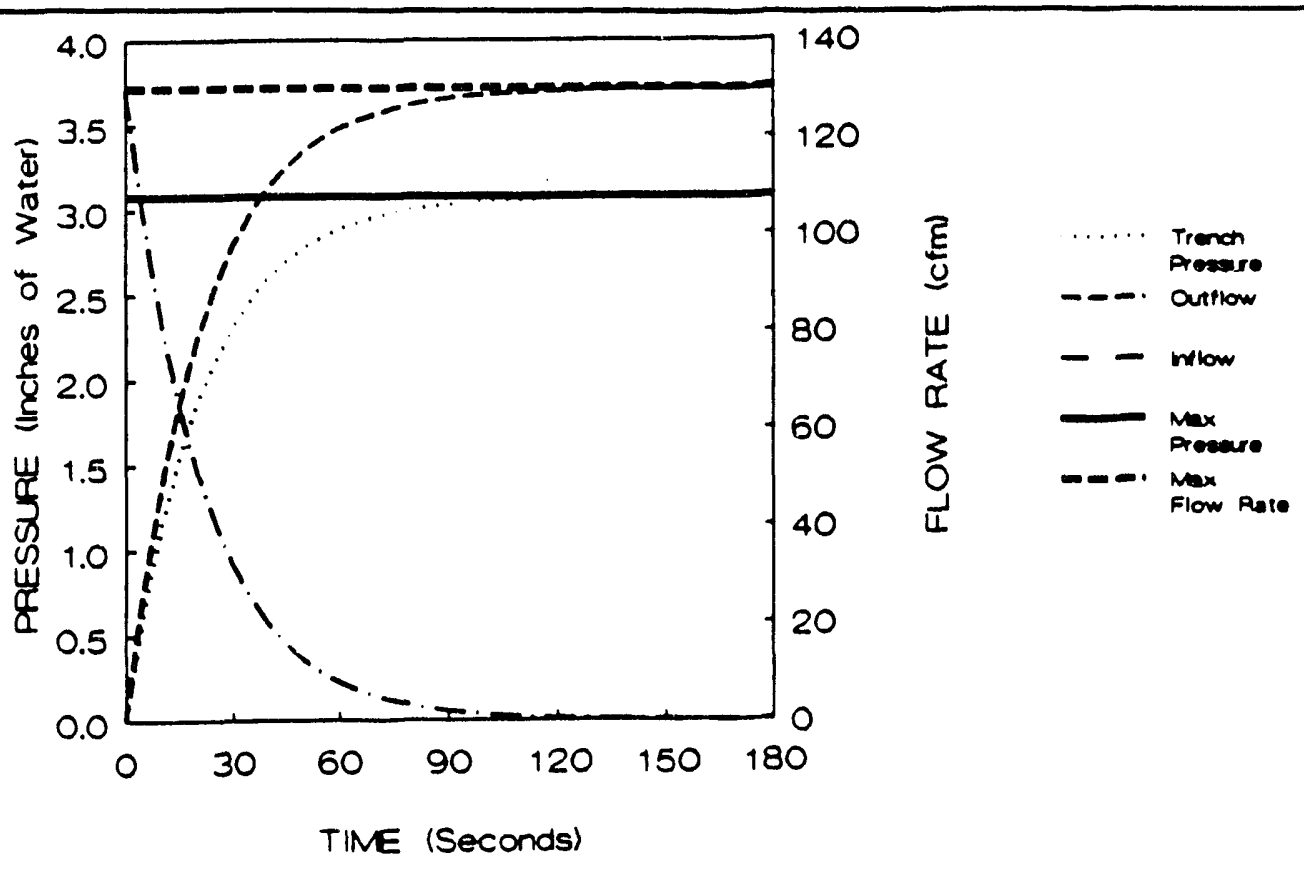

Fig. 5. Reaching uniform pressure within trench using constant flow input. 
from Eq. (8)

$$
F_{i}=F_{c} e^{-B_{1} t}
$$

and the volume attributed to the pressure change in the trench $\left(V_{l}\right)$ can be determined by integrating the net flow rate $(F)$ with respect to time

$$
V_{1}=\int F_{c} e^{-B_{1} t} d t=\frac{F_{c}}{B_{1}} .
$$

To implement this technique, compressed air was pumped into eac't of the trenches using at least three injection wells for each trench. Pressure as a fur ztion of time was also monitored in each of the trenches by using pressure gauges installed in at least three monitoring wells for each trench. These data provided estimates for $V_{1}$ from which $V_{o}$ can be calculated from

$$
V_{o}=\frac{V_{1} P_{c}}{P_{c}-P_{o}}
$$

where $V_{l}=$ volume of net inflow, $P_{c}=$ trench pressure $\left(P_{c g}+P_{o}\right)$ at constant inflow, and $P_{o}=$ initial pressure $(1 \mathrm{~atm})$.

\subsubsection{Trench Pressurization-Applied}

Before any pressurization tests were conducted, the trench air was sampled for volatile organic compounds. Analyses revealed detectable levels of acetone, tetrachloroethene, 1,1,1-trichloroethane, ethylbenzene, styrene, vinyl acetate, trichloroethene, and benzene, none of which were judged to be in hazardous quantities (B. A. Jerome, Industrial Hygiene Department, ORNL to C. W. Francis, ESD, ORNL, June 1990). To conduct the trench pressurization tests, a high-volume compressor (Ingersoll Rand, Model P-185-W-JD, capable of delivering $185 \mathrm{cfm}$ at $100 \mathrm{psi}$ ) was used to force air into the trench. However, before any pressurization tests were carried out at the well heads, outgoing trench air was monitored using real-time instrumentation for volatile organic compounds and radionuclides. None was detected.

Pressure at the top of the slotted injection wells was monitored using Magnehelic pressure gages (Model 2010 Dwyer Instruments, Marietta, Georgia) capable of measuring pressure ranges from 0 to 10 in. of water ( $\pm 2 \%$ accuracy). The compressor was used to pump air into the trenches at rates ranging from 40 to $130 \mathrm{cfm}$. Air-pumping rates were determined using an in-line flowmeter (Hedland, Model 03228), which was capable 
of direct readout of flows ranging from 20 to $220 \mathrm{cfm}$ ( $\pm 5 \%$ accuracy). Polyvinyl tubing ( 0.75 in. ID) was used to deliver air th the injection wells. Several configurations were used to pump air into the trenches [single injection at one end of the trenches (injection well 151-10) and in the center of the two trenches (injection well 170-10) in addition to a multiple injection configuration (injection wells 151-1, 151-7, 151-10, 170-1, 170-10, and 170-12, see Fig. 3]. The principle of the technique required monitoring pressure response over time as a constant flow of air was pumped into the trenches (see Fig. 5). Pressure response was measured at four injection wells in each of the two trenches (total of eight wells). Four investigators manually recorded the pressure response over time (this had to be done rather quickly because constant pressure was usually achieved in $<4 \mathrm{~min}$ ).

\subsubsection{Water Pump-In. Tests}

Trench void volumes can be determined by filling a trench or connected trenches with water (Spalding 1986; Tamura et al. 1987). To determine void volumes by this methori, water levels within a burial trench were monitored as the trench was filled with water at a measured pump raic. The trench can be divided into several region or depth increments, starting at the trench bottom. Seepage rates out of each trench region can be calculated from the time of recession of water level as the trench drains. A seepage rate for each region can be salculated as

$$
X_{s}=\frac{X T_{f}}{T_{s}+T_{f}}
$$

where

$$
\begin{aligned}
& X_{s}=\text { seepage rate, } \mathrm{yd}^{3} / \mathrm{h}, \\
& X_{f}=\text { water delivery rate, } \mathrm{yd}^{3} / \mathrm{h}, \\
& T_{f}=\text { region's filling time, } \mathrm{h}, \\
& T_{s}=\text { region's emptying time, } \mathrm{h} .
\end{aligned}
$$

A net filling rate for each region was then calculated as

$$
X_{n}=X_{f}-X_{s}
$$

where

$$
\begin{aligned}
& X_{n}=\text { net filling rate, } \mathrm{yd}^{3} / \mathrm{h} \\
& X_{f}=\text { water delivery } \mathrm{rate}^{3}, \mathrm{yd}^{3} / \mathrm{h} \\
& X_{s}=\text { seepage rate, } \mathrm{yd}^{3} / \mathrm{h} .
\end{aligned}
$$

Finally, the region void volume was calculated as 


$$
V_{f}=X T_{f}-X_{s} T_{f}
$$

where

$$
V_{f}=\text { void volume of the region, } \mathrm{yd}^{3} \text {. }
$$

The regional void volumes were then summed to yield the total water-accessible trench void volume, and this, in turn, was expressed as a percentage of the total trench volume. Table 4 summarizes the calculations of water-accessible trench void volumes made for

Table 4. Summary of calculations of water-accessible void volumes derived from

\begin{tabular}{|c|c|c|c|c|c|c|c|c|c|c|}
\hline \multirow[t]{3}{*}{ Region } & \multicolumn{2}{|c|}{ Elevation } & \multirow{2}{*}{$\begin{array}{c}\text { Region } \\
\text { height }\end{array}$} & \multirow{2}{*}{$\begin{array}{l}\text { Flow } \\
\text { rate } \\
\text { yd'h }\end{array}$} & \multirow{2}{*}{$\begin{array}{c}\text { Region } \\
\text { fill } \\
\text { time } \\
\\
\text { h }\end{array}$} & \multirow{2}{*}{$\begin{array}{c}\text { Region } \\
\text { empty } \\
\text { time }\end{array}$} & \multirow{2}{*}{$\begin{array}{c}\text { Seep } \\
\text { rate } \\
\\
\mathrm{yd}^{3} / \mathrm{h}\end{array}$} & \multirow{2}{*}{$\begin{array}{c}\text { Net } \\
\text { fill } \\
\text { rate } \\
\text { yd } d^{3} / h\end{array}$} & \multicolumn{2}{|c|}{$\begin{array}{c}\text { Void } \\
\text { volume }\end{array}$} \\
\hline & $\mathfrak{f t}$ & ft. & & & & & & & $y d^{3}$ & $\%$ \\
\hline & & & & $x_{1}$ & $T_{1}$ & $\mathrm{~T}_{1}$ & $\mathrm{x}$ & $x$ & & \\
\hline & \multicolumn{10}{|c|}{ Trench 6} \\
\hline 1 & 826.56 & 829.84 & 3.28 & 4.09 & 2.25 & 41.25 & 0.21 & 3.88 & 8.74 & 11.74 \\
\hline 2 & 829.84 & 833.12 & 3.28 & 4.09 & 4.25 & 20.75 & 0.69 & 3.40 & 14.44 & 19.40 \\
\hline 3 & 833.12 & 836.40 & 3.28 & 4.09 & 5.00 & 13.65 & 1.10 & 3.00 & 14.98 & 20.13 \\
\hline 4 & 836.40 & 840.04 & 3.64 & 4.09 & 4.25 & 3.50 & 2.25 & 1.84 & 7.86 & 9.51 \\
\hline \multirow[t]{2}{*}{ Total } & & & 13.48 & & & & & & 46.01 & 15.04 \\
\hline & \multicolumn{10}{|c|}{ Trenches 151 and 170} \\
\hline 1 & 824.46 & 828.59 & 4.13 & 5.65 & 13.67 & 150.87 & 0.47 & 5.18 & 70.75 & 38.63 \\
\hline 2 & 828.59 & 833.25 & 4.66 & 5.56 & 24.03 & 9.66 & 3.96 & 1.60 & 38.28 & 19.65 \\
\hline 3 & 833.25 & 834.86 & 1.61 & 11.14 & 2.98 & 0.72 & 8.99 & 2.16 & 6.46 & 9.07 \\
\hline Total & & & 10.40 & & & & & & 115.49 & 25.06 \\
\hline
\end{tabular}
trench water pump-in tests 
burial trenches 6 and 151/170 using this method.

Water was pumped from the emergency waste-holding basin to the north of the TARA site into the burial trenches. Trench 6 was filled between October 28 and November 2, 1987, and received $72 \mathrm{yd}^{3}(14,440 \mathrm{gal})$ of water. Trenches 151 and 170 were filled between August 3 and 6, 1987 and received $362 \mathrm{yd}^{3}(73,103 \mathrm{gal})$ of water. Water was delivered to the trenches through a $2.5-\mathrm{cm}$ rubber hose run to the bottom of one of the intratrench wells. The water delivery was allowed to continue overnight under continuous surveillance until water level monitoring in additional intratrench wells indicated that the water was within $1.5 \mathrm{ft}$ of the ground surface. When the pump was turned off, the water levels in the observation wells were monitored periodically until the trench was completely drained. This made possible the determination of seepage rates required to correct for seepage during the water delivery interval. Water levels, or more frequently the lack of standing water, in neighboring trenches were also monitored during the filling and draining intervals to identify any hydrologic connection among the burial trenches.

The pump-in test on trench 6 approached an ideal situation (Fig. 6). The pumping rate during filling was quite constant and uninterrupted. Water levels in the three wells, distributed over the length of the trench, rose and fell very uniformly. Not all these wells penetrated completely to the trench bottom; therefore, water levels did not recede

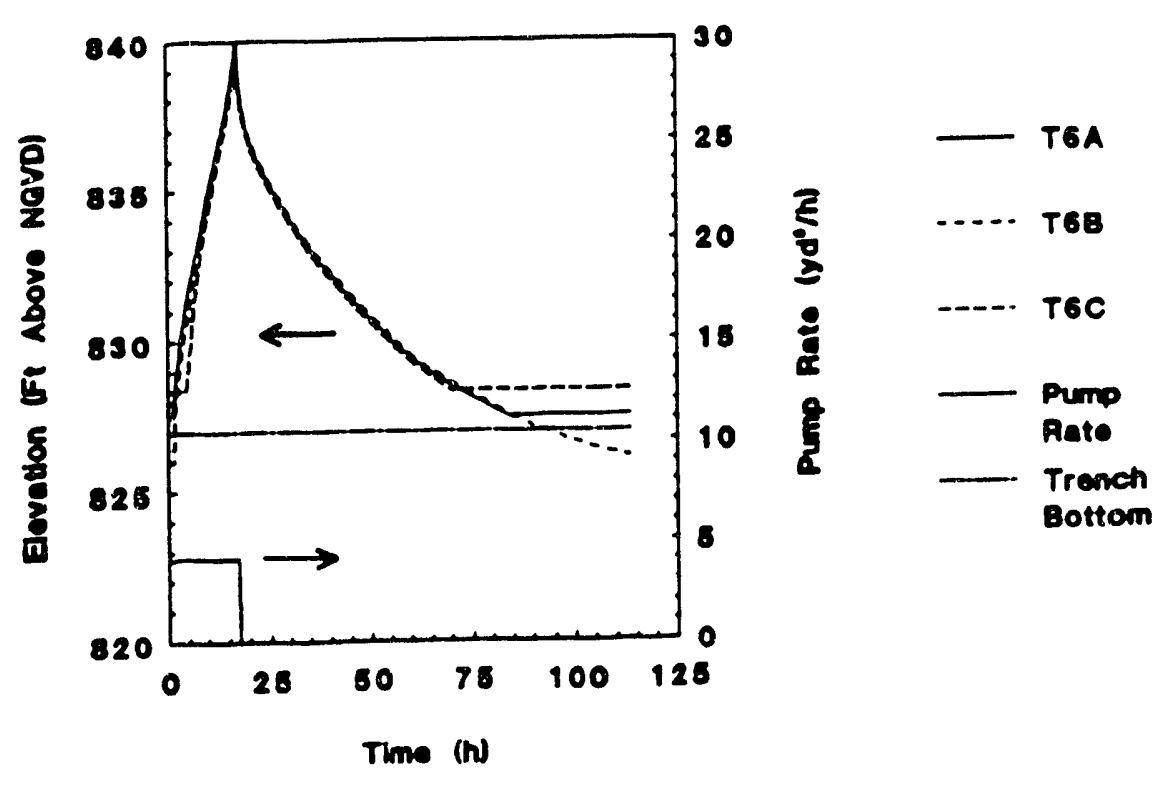

Fig. 6. Hydrograph of water elevations during the pump-in tests on trench 6. 
below a small cup in the bottom of the well casings. Although not shown, water levels in nearby burial trenches, notably trenches 5 and 7 (Fig. 1) were not observed during trench filling or recession which indicates that water was not filling voids other than in trench 6.

In contrast, the pump-in test of trenches 151 and 170 (Fig. 7) was not as ideal as that obtained on trench 6 . The pumping rate was not uniform; the pump actually stopped for several hours between late-night and early-morning checks. Later the water delivery line began to leak, and the pumping rate, as measured at the wellhead, declined. Adjustments of pump speed were made in an attempt to maintain a constant delivery rate, but the leak became progressively more serious, and finally a section of the line had to be replaced. However, at this point the rate of trench filling was such that to avoid having to terminate pumping and monitor water levels at short intervals during the middle of the night, pumping was accelerated by the addition of a second pump, with the concomitant doubling of delivery rates, for several hours near the end of trench filling.

In addition, water levels for two of the three monitoring wells in trench 151, into which water was pumped, exhibited a lag compared with the well nearest the point of discharge (T151A). The well in trench 170 (T170) exhibited an even more pronounced lag. When the pumps were turned off, water levels within trenches 151 and 170 became uniform during recession. Unlike the trench 6 test, water was observed in adjicent

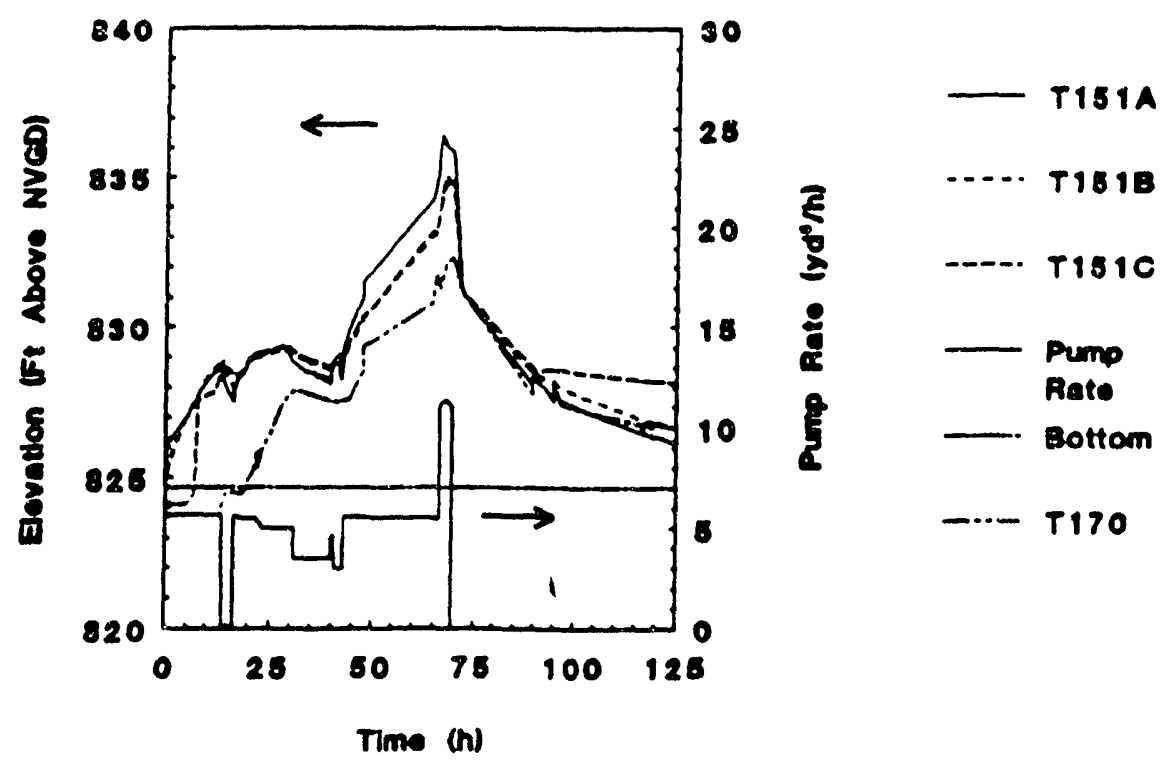

Fig. 7. Hydrograph during water pump-in test on trenches 151 and 170. 
trenches, particularly trenches 148 and 159 . However, trench 159 did not exhibit a measurable water level until after the pump was tumed off. Trench 148 did, however, exhibit about a 6-ft rise in water level, indicating that it contributed a significant fraction to the measured void volume (Table 4). However, because of the nature of the void calculation, the pumping aberrations can be disregarded and an effective filling hydrograph (Fig. 8) can be used to determine filling and emptying times and pumping rates.

The "measured" voids in trenches 151 and 170 amounted to $115 \mathrm{yd}^{3}$ (23,328 gal). However, this volume does not include the top region of trench 170 between 832.4 and $834.7 \mathrm{ft}$ above National Geodetic Vertical Datum (NGVD), but it does include voids in trench 148 between 824.3 and $829.2 \mathrm{ft}$ above NGVD. Thus, the measured voids in trenches 150 and 170 are estimated to be within $\pm 20 \%$ of the calculated amount. Interestingly, the distribution of voids with depth in trenches 6 and 150 and 170 offered some contrast. Most of the voids in trenches 150 and 170 were in the bottom half trench regions, and the lowermost $4-\mathrm{ft}$ region contained $38 \%$ voids. In contrast, trench 6 exhibited about $12 \%$ voids in the lowermost region and was more uniform in distribution of percentage of voids with depth. This large void volume in the lower part of trenches 150 and 170 may explain the frequent encounter with penetration resistant material at this depth below the ground surface after filling the trench with grout.

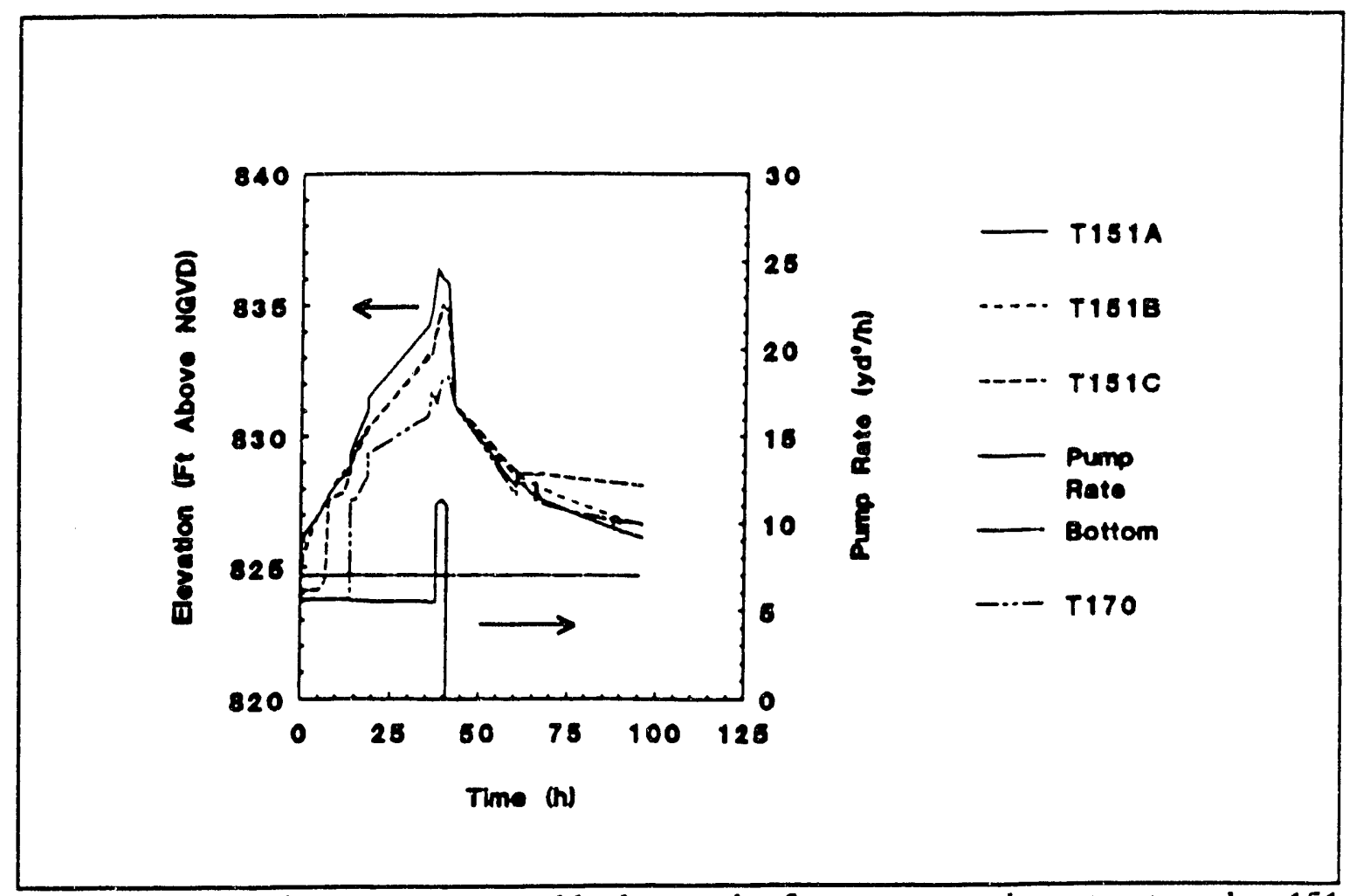

Fig. 8. An effective or compressed hydrograph of water pump-in test at trenches 151 and 170 . 


\subsection{GROUNDWATER MONITORING}

The water table at this site is $\sim 20 \mathrm{ft}$ below the bottoms of the trenches. In June 1990 the only wells inside or outside the trench area to contain water were wells $165-\mathrm{NW}$ and 165-SW. With the use of a peristaltic pump and Teflon tubing, water samples were collected from these wells on June 20, 1991, (before grouting) and February. 8, 1991, (after grouting). The quantity sampled from either of the two wells on either of the sampling dates was $<500 \mathrm{~mL}$ because of the slow recharge to the wells. Water taken from these wells is seepage water collected in the bottom of the wells following heavy rainfalls. The permanent water table is $>15 \mathrm{ft}$ below the bottom of these wells. These samples were acidified to $\mathrm{pH}<2$ using Ultrex nitric acid and analyzed (without filtration) for radioactivity (gross alpha and beta and ${ }^{90} \mathrm{Sr}$ concentrations using EPA methods 900 and 905 , respectively). Concentrations of metals were determined by Inductive Coupled Plasma spectrometry (EPA method 200.7).

\subsection{GROUT FORMULATION AND TESTING}

The performance criteria established for grout formulation were the same as that used by Tamura et al. (1987):

$\begin{array}{ll}\text { Apparent viscosity } & <50 \mathrm{cP} \\ \text { 10-min gel strength } & <100 \mathrm{lb}_{\mathrm{f}} / 100 \mathrm{ft}^{2} \\ \text { 28-d phase separation } & 0 \text { volume } \% \\ \text { 28-d compressive strength } & >60 \mathrm{psi}\end{array}$

Other tests included penetration resistance and consistency.

The dry solid materials used to develop the grout formulation included the following: two cements (a Type 1 Portland cement obtained from Dixie Cement Company, Knoxville, Tennessee, and a microfine grade of cement produced by kilning finely ground blast-furnace slag, which is merchandized as MC-100 by Geochemical Corporation, Ridgewood, New Jersey), two coal-fired utility fly ashes (an ASTM Class F ash from Owensboro, Kentucky, and an ASTM Class C fly ash from Rockport, Illinois), and a cement-grade Wyoming bentonite (CAS No. 1318-93-0, 80\% passing a 200 mesh screen) from Wyo-Ben, Inc., Billings, Montana. Data in Table 5 characteristically represent the chemical analyses of the fly ashes and cements. Three blends were tested: one for each of the fly ashes mixed at $39 \%_{\mathrm{w}}$ Type I Portland cement, $55 \%$ w fly ash, and $5.5 \%$ wyoming bentonite, and one using $100 \%, \mathrm{MC}-100$ cement. Blends 1 and 2 contained class $\mathrm{C}$ and $\mathrm{F}$, respectively, and blend 3 contained the MC- 100 cement. The weight of dry solids added to a given volume of liquid (the mix ratio) for grouts containing the fly ashes was 12.0 to $12.5 \mathrm{lb} / \mathrm{gal}$, and a mix ratio of 7.5 to $8.0 \mathrm{lb} / \mathrm{gal}$ was used for the grouts made with the MC-100 microfine cement. The standardized test procedures as indicated in the following were all performed in triplicate. 


\subsubsection{Phase Separation Tests}

Phase separation refers to a separate liquid or water phase that collects at the top of a freshly mixed grout. With proper formulation, the volume of liquid is usually found to increase for a short period (1 d) after the grout is mixed and then to decrease to dryness with additional cure time. The volume of liquid was determined by a settling test in a $250-\mathrm{mL}$ graduated cylinder (Tallent et al. 1987). A known volume of freshly mixed grout is poured into the cylinder; then the cylinder is capped and allowed to stand for the time intervals of interest (typically, up to $28 \mathrm{~d}$ ).

The phase separation (in vol \%) is calculated as the volume of clear drainable surface liquid (hereafter referred to as drainable water) divided by the original grout volume.

The method (based on the standardized ASTM C192-81 procedure) for preparing grouts for the phase separation tests in which blends 1 and 2 were used are as follows: The appropriate weight of a given dry solid blend was added to $1.0 \mathrm{~L}$ of water containing $0.300 \mathrm{~g}$ of delta-gluconolactone (sugar) in a Hobart Model N-50 mixer. The solids-to-water ratio was $12 \mathrm{lb} / \mathrm{gal}$. The addition was made over a period of $30 \mathrm{~s}$ at low mixer speed (setting 1). The mixing was continued at low speed for another $30 \mathrm{~s}$ and then increased to medium speed (setting 2) for another $30 \mathrm{~s}$. The procedure for blend 3 (100\% MC-100 cement) was different in that $85.25 \mathrm{~mL}$ of a $50 \% \mathrm{NaOH}$ solution and $9.5 \mathrm{~mL}$ of CA-600 dispersant (marketed by Geochemical Corporation, Ridgewood, New Jersey) were added to $1250 \mathrm{~mL}$ of water, and the appropriate weight of the blend added. The mixing times were identical to those for grouts prepared using blends 1 and 2 .

\subsubsection{Compressive Strength Tests}

Compressive strength is a measure of the ability of cured grout to support an applied axial load. Low compressive strength (allowing easy crushing) usually corresponds to more porous grout with the possibility of increased leaching compared 
with grouts having high compressive strengths. The specimens for unconfined compressive strength tests were prepared by pouring freshly prepared grout into 2-in.-cube stainless steel molds and allowing the molds to stay in a humidity cabinet ( $90 \%$ relative humidity) at room tempera:ure for $28 \mathrm{~d}$. Crushing strengths of the grout cubes were then determined by using a Model 60,000 , Super " $L$ " Tinius-Olsen Testing Machine. The freshly mixed grouts were prepared following the same procedure as that used for the drainable water tests.

\subsubsection{Penetration Resistance}

Penetration resistance is a method used to measure cementitious setting progress as a function of time. Measurements were made using an ACME Penetrometer apparatus from Humboldt Manufacturing Company. Grouts for the measurements were prepared using the same procedure as that used for the phase separation tests. Samples of the grouts, $130-\mathrm{mL}$ volumes, were poured into PVC cups, and the penetration resistance measurements were made at time intervals until setting occurred.

\subsubsection{Apparent Viscosity}

Viscosity of a grout (a non-Newtonian fluid) varies with shear rate. In these tests the viscosity was measured at $300 \mathrm{rpm}$ with a Fann Direct Reading Viscometer, Model 135A. This viscosity is commonly referred to as apparent viscosity.

\subsubsection{Gel Strength}

The 10-min gel strength is indicative of the force required to restart the flow of grout after it has remained stationary for $10 \mathrm{~min}$. The measurement is made in the Fann Viscometer with the same grout sample following other rheological measurements. After the grout has been allowed to stand in the viscometer for $10 \mathrm{~min}$ without stirring, the instrument is tumed on with the shear rate set at $3.0 \mathrm{rpm}$. The 10-min gel strength in $\mathrm{lbs} / 100 \mathrm{ft}^{2}$ is read directly from the viscometer at the maximum deflection on the shear stress scale.

\subsubsection{Consistency}

The viscosity or consistency of freshly prepared grout varies as a function of time but usually remains fairly constant for a few hours after mixing and then increases rapidly as hydration reactions and setting processes begin. Consistency was determined by using a Model 123 Cement Consistometer from Halliburton Services. 


\subsection{FIELD GROUT MIXING AND INJECTION}

Grout solids were dry-blended (using existing equipment at the New Hydrofracture Facility) and then mixed with water in a concrete mixing truck. Each truck-load contained 6.33 tons of dry blend $(2.47,3.52$, and 0.35 tons of cement, fly ash, and clay, respectively) and $1000 \mathrm{gal}$ of water containing $1 \mathrm{lb}$ of delta gluconolactone (used as a dispersant and set retarder for the grout). The density of the grout was $13.5 \mathrm{lb} / \mathrm{gal}$; thus, each truck-load contained $\sim 7.7 \mathrm{yd}^{3}$. Grout from the concrete mixing truck was transferred to the grouting module using a grout pump furnished by Con-Quip, Inc., Maryville, Tennessee. The grouting module was designed and constructed at ORNL in 1982 (ORNL engineering drawing No. J3DI2534). The module contains two 500-gal mixing tanks (each with single propeller lighting mixers) and two progressive cavity pumps capable of pumping $30 \mathrm{gpm}$ of grout at pressures up to $200 \mathrm{psi}$ (see Fig. 9). One of the two pumps was used to pump grout from the grouting module via 1-in.-diam. high-pressure hose to a single injection well. Pressure at the grouting module was maintained manually at levels ranging from 50 to 100 psi. Grouting pressure at the injection well was usually $<10$ psi; however, as the available void space became full of grout, pressures up to 50 and 75 psi were observed, making it necessary to move to another injection well.

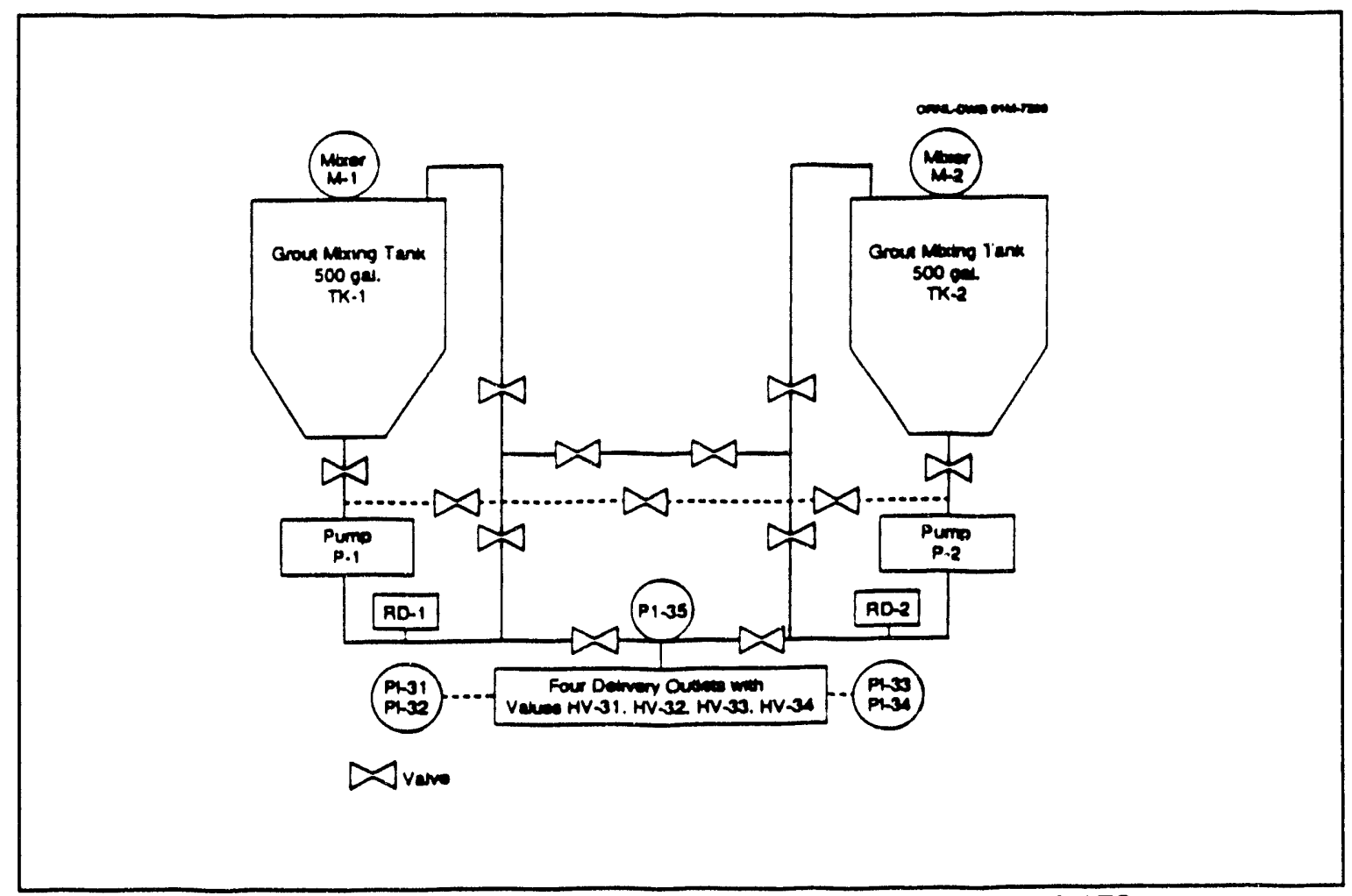

Fig. 9. Grouting module used to inject grout in trenches 151 and 170. 


\section{RESULTS AND DISCUSSION}

\subsection{SELECTION OF GROUT FORMULATION}

Prototype development of grouting formulation was conducted by T. Tamura. Three blends were recommended for testing. Grouts made from each of the three blends met or exceeded established criteria (Table 6). Along with the criteria listed in Table 6 two additional criteria, penetration resistance and fluid consistency, were tested. If one assumes that penetration resistance readings in excess of 4000 psi reflect complete setting of cements, then all three blends set in $<3 \mathrm{~d}$ (Table 7). Results from the consistometer tests revealed that grouts made from the Class $\mathrm{F}$ fly ash possessed a considerably longer field time before setting began. For example, the data indicated that grouts made from

Table 6. Results of laboratory grout tests

\begin{tabular}{ccccc}
\hline Parameter & Criteria & 1 & 2 & 3 \\
\hline Apparent viscosity & $<50 \mathrm{cP}$ & $35 \pm 1$ & $37 \pm 1$ & $10 \pm 1$ \\
10-min gel strength & $<100 \mathrm{lb}_{\mathrm{d}} 100 \mathrm{ft}^{2}$ & $30 \pm 3$ & $28 \pm 7$ & $7 \pm 1$ \\
28-d phase separation & 0 vol\% & 0 & 0 & 0 \\
28-d compressive strength & $>60 \mathrm{psi}$ & $1601 \pm 17$ & $908 \pm 28$ & $2000 \pm 253$ \\
\hline \hline
\end{tabular}

${ }^{\circ}$ Blend 1 contained $39 \%$ Type 1 Portland cement, $55.5 \%$ Class $\mathrm{C}$ fly ash, and $5.5 \%$ bentonite mixed at $12-12.5 \mathrm{lb} / \mathrm{gal}$ of water. Blend 2 contained $39 \%$ Type 1 Portland cement, $55.5 \%$ Class $\mathrm{F}$ fly ash, and $5.5 \%$ bentonite mixed at $12-12.5 \mathrm{lb} / \mathrm{gal}$ of water. Blend 3 contained $100 \% \mathrm{MC}-100$ microfine cement mixed at $7.5-8.0 \mathrm{lb} / \mathrm{gal}$ of water.

Class $\mathrm{F}$ fly ash could be pumped for periods up to 7 to $8 \mathrm{~h}$, whereas grouts made of the Class $\mathrm{C}$ fly ash may display considerable thickening that would inhibit pumping at periods longer than 5 to $6 \mathrm{~h}$. Grouts made from the microfine cement displayed substantially less consistency (bearden units $<5$ ) during the first $6 \mathrm{~h}$ compared with grouts made of fly ash (bearden units $>10$ ). The addition of $0.02 \%$ delta-gluconolactone to the water used to make the microfine cement grouts extended pumping times from 4 to $10 \mathrm{~h}$. Because of the longer pumping times of grouts made from Class $\mathrm{F}$ fly ash compared with those of the Class $\mathrm{C}$ fly ash, it was recommended that the grout formulation made from the Class F fly ash be used for grouting trenches 151 and 170 . The grout made from the microfine cement appeared to be technically acceptable; however, there was concern that it may be difficult to develop sufficient shear to adequately mix this grout formulation in the field using a cement mixer truck. This factor, plus the fact that material costs for the microfine cement grout were on the order 
Table 7. Grout formulation penetration-resistance results

\begin{tabular}{lccc}
\hline \multicolumn{1}{c}{ Blend tested } & \multicolumn{3}{c}{$\begin{array}{c}\text { Resistance } \\
\text { (psi) }\end{array}$} \\
& Day 1 & Day 2 & Day 3 \\
\hline Blend 1 (Class C fly ash) & $453 \pm 11$ & $4133 \pm 167$ & $>8000$ \\
Blend 2 (Class F fly ash) & $247 \pm 42$ & $>8000$ & $>8000$ \\
Blend 3 (Microfine cement) & $>8000$ & $>8000$ & $>8000$ \\
\hline
\end{tabular}

of ten times higher than conventional cement/fly ash grouts, made the choice of microfine cement less attractive.

\subsection{SOIL-PENETRATION TESTS}

\subsubsection{Pregrout Soil-Penetration Tests}

Pregrouting soil-penetration tests within the trench area revealed that as the depth of penetration increased, an increasing number of blows were required to drive the cone farther into the ground (Fig. 10). Mean blows per foot inside the trench area were significantly less than mean blows per foot into soils outside the 151 and 170 trenches. Generally speaking, at soil depths $>5$ and $<15 \mathrm{ft}$, mean blows per foot within the trench averaged on the order of 20 blows per foot below that outside the trench, implying considerable uncompacted soil or void space within the trench area. Plots of the blows per foot with respect to depth illustrate that specific areas within the trench are more compacted than others. For example, test 11 and to some extent test 10 in trench 170 revealed a compacted area near the bottom of the trench where injection of grout may be more difficult than at other locations in the trench (Fig. 11). A similar point could be made about tests 4 and 6 in trench 151 (Fig. 12).

A summary of all pregrouting soil-penetration tests conducted in trenches 151 and 170 is presented in Table 8. Again, tests 4 and 6 in trench 151 (22.3 and 17.5 mean blows per foot, respectively) indicate that injection of grout into the trench at these sites may be more difficult than injection at the southwest end of the trench (tests 9 and 10 , see Fig. 3) where mean blows per foot ranged between 5 and 7 . On the other hand, the midsection of trench 170 appears to be less compacted than either of the ends. For example, mean blows per foot were $<10$ for tests $3,4,5,6$, and 12 , whereas those at either end (tests 1,2 , and 7, 8, 9, 10, and 11 , see Fig. 3) were generally $>10$ (Table 8). 


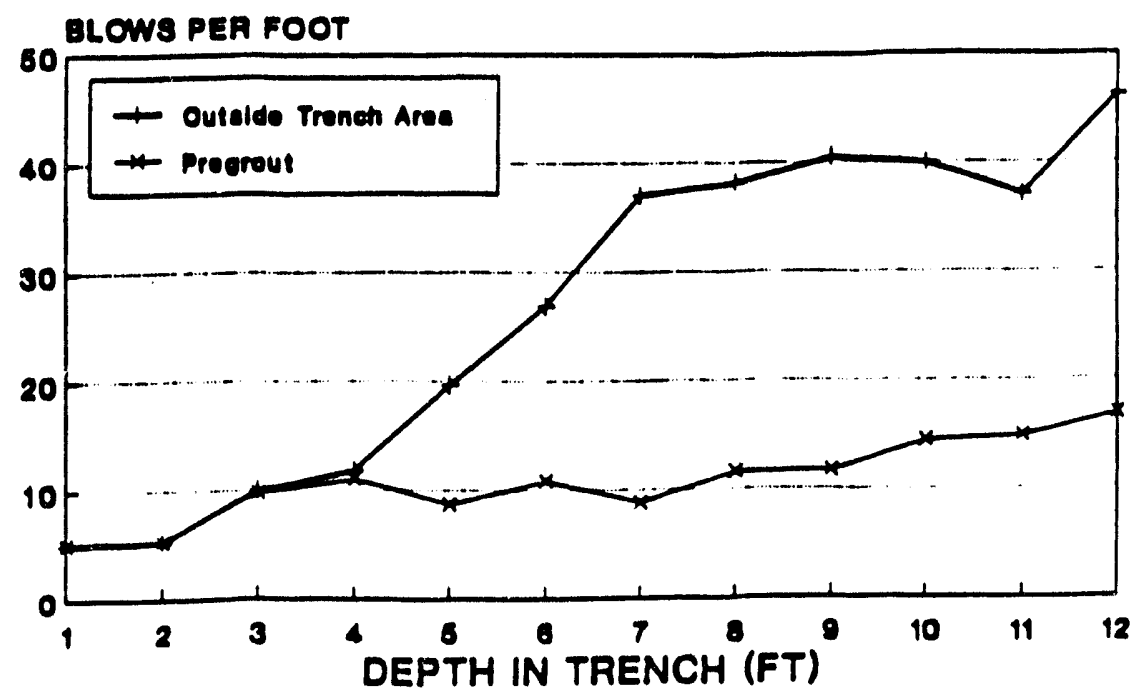

Fig. 10. Summary of pregrouting soil penetration tests inside and outside trench area.

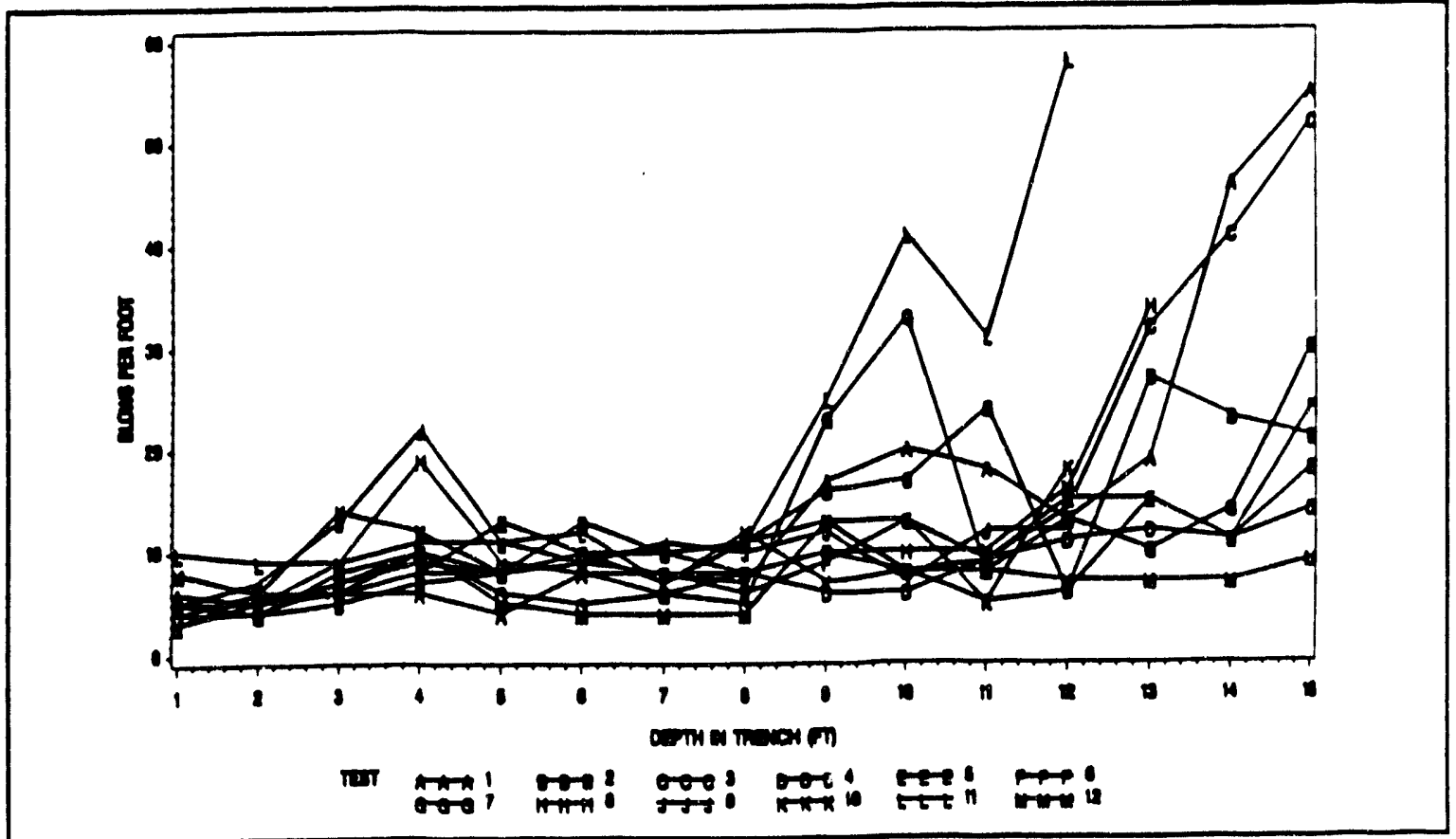

Fig. 11. Pregrout soil penetration results inside trench 170. 


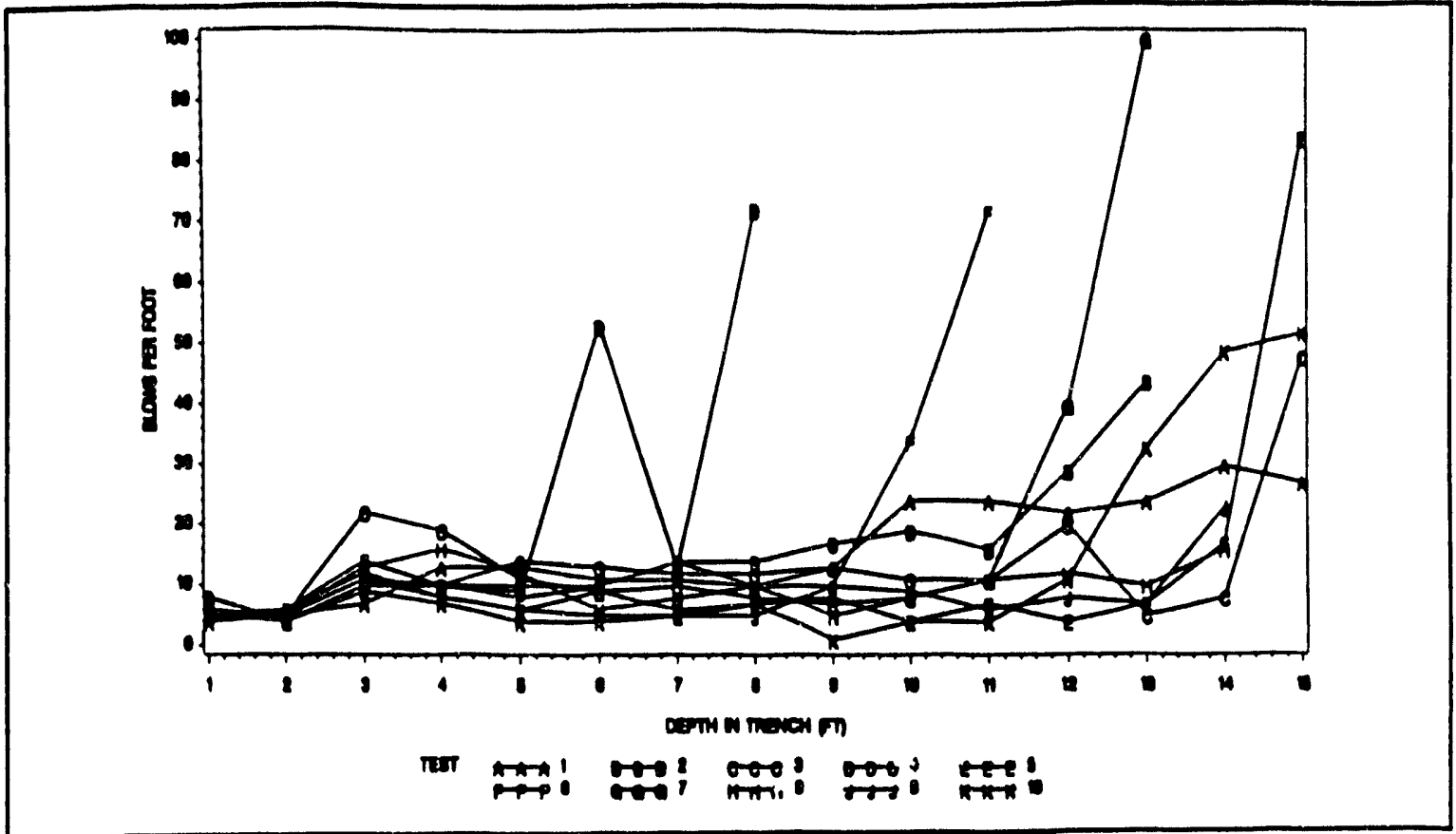

Fig. 12. Pregrouting soil penetration results inside trench 151.

\subsubsection{Postgrouting Soil-Penetration Tests}

In January, 1991, -6 months following grouting, soil-penetration tests were conducted within and adjacent trenches 151 and 170. These tests, to soil depths of $15 \mathrm{ft}$ (see Table 2), included ten tests within trench 170 and 12 tests within trench 151 (four were also conducted outside of but adjacent to the trenches). Refusal (i.e., $>100$ blows to penetrate one foot) was encountered in 17 of the 22 tests conducted within the trench area, resulting in mean refusal depths of 11.5 and $8.5 \mathrm{ft}$ in trenches 151 and 170 , respectively. Results from the postgrouting soil-penetration tests revealed that the stability of the trench after grouting was significantly better than before grouting, and at depths $>8 \mathrm{ft}$, the stability (measured in terms of soil penetration) was very near that observed outside the trench (Fig. 13). For example, soil penetration in mean blows per foot at depths $>8 \mathrm{ft}$ within the trench was very similar to those measured outside the trench.

Pregrouting tests ranged from 10 to 20 mean blows per foot whereas postgrouting tests ranged from 20 to 40 mean blows per foot. Only at soil depths of 6,7 , and $8 \mathrm{ft}$ were there major differences between postgrout tests and tests conducted outside the trench (Fig. 13). The lower stability exhibited in this range (5 to $8 \mathrm{ft}$ ) probably reflect the presence of intermediate-size soil voids (formed during backfilling) that were not penetrated by the conventional cement grout formulation. A statistical summary of the soil-penetration tests (before and after grouting as well as those outside the trench area) as a function of soil depth is presented in Appendix A. 
Table 8. Summary of pregrouting soil-penetration tests in trenches 151 and 170

\begin{tabular}{lrrrrrrrr}
\hline & \multicolumn{7}{c}{ Blows per foot } \\
Test & \multicolumn{7}{c}{ Trench 151 } & \multicolumn{5}{c}{ Trench 170 } \\
& Mean & Min & Max & SD & Mean & Min & Max & SD \\
\hline 1 & 13.1 & 4 & 24 & 6.9 & 9.8 & 4 & 20 & 5.6 \\
2 & 13.4 & 4 & 29 & 6.5 & 10.5 & 4 & 24 & 6.1 \\
3 & 11.3 & 5 & 22 & 5.8 & 8.4 & 4 & 14 & 2.5 \\
4 & 22.3 & 5 & 72 & 25.5 & 7.5 & 4 & 11 & 2.2 \\
5 & 6.8 & 4 & 12 & 2.2 & 9.7 & 3 & 15 & 3.5 \\
6 & 17.5 & 4 & 72 & 19.7 & 7.3 & 3 & 13 & 2.6 \\
7 & 12.9 & 5 & 40 & 9.1 & 10.5 & 4 & 33 & 8.8 \\
8 & 9.3 & 5 & 16 & 3.5 & 9.6 & 5 & 19 & 4.2 \\
9 & 6.9 & 5 & 11 & 2.2 & 10.9 & 5 & 22 & 4.3 \\
10 & 5.4 & 1 & 11 & 2.7 & 9.2 & 3 & 18 & 4.2 \\
11 & & & & & 19.6 & 7 & 58 & 16.1 \\
12 & & & & & 6.9 & 4 & 13 & 2.7 \\
\hline
\end{tabular}

\subsection{VOID VOLUME MEASUREMENTS}

\subsubsection{Preliminary Pressurization Tests}

As an alternative to water pump-in tests, an air-pressurization technique was used to compare the accuracy and operational features of the two techniques. Preliminary pressurization tests included a series of tests to determine the extent of intervoid connection between trenches 151 and 170. For example, air was injected at one end of trench 151 (injection well 151-10, see Fig. 14) to determine if pressure differences could be detected in wells at the farther end of trenches 151 and 170. Other tests included air injection in a single well in trench $170(170-10)$ and multiple injections at six wells $(151-1,151-7,151-10,170-1,170-10,170-12)$. Three flow rates were used in each test to confirm that pressure measured at the monitoring wells was a function of airflow into the trenches (see Table 9).

In most cases, the monitoring wells were the wells constructed as injection wells 
BLOWS PER FOOT

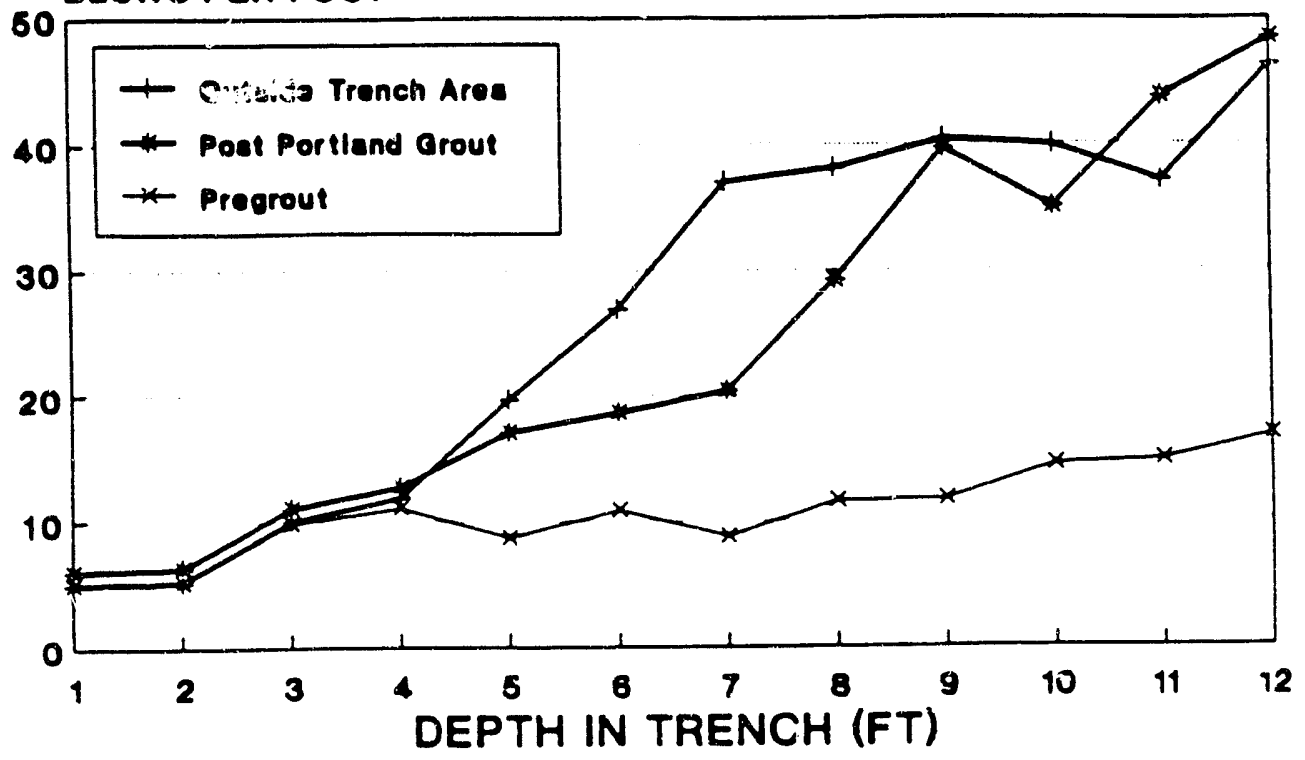

Fig. 13. Summary of soil penetration tests.

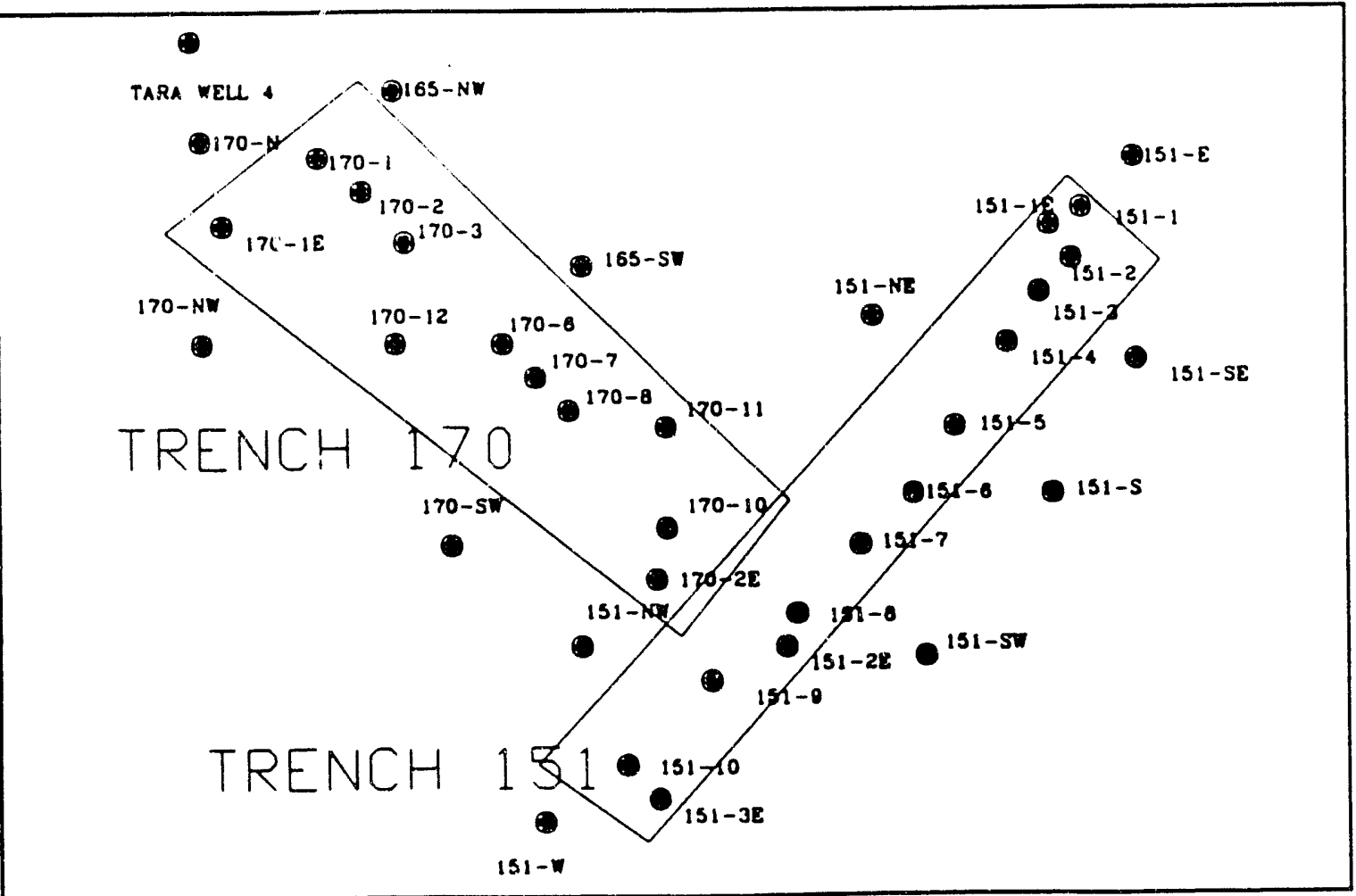

Fig. 14. Location of trench wells used for pressurization tests. 
for grout (see Fig. 3); however, in several instances, air pressures were monitored at existing wells within the trench area (labeled as 151-1E, 151-2E, 151-3E, 170-1E, and 170-2E in Fig. 14). Three of these wells (151-2E, 151-3E, and 170-1) were constructed of 6-in.-diam corrugated steel reaching to the bottom of the trench. The other existing wells were constructed of 2.5-in.-diam. aluminum tubing, also to the bottom of the trenches. The width and interval of slotting or the overall length of screened section for either of these existing well types is unknown. Slotted PVC pipe with solid top sections, similar to that used for the grouting injection wells, were placed into these existing wells. Then a cement-based grout collar was molded to $\sim 1 \mathrm{ft}$ below the ground surface for the purpose of sealing the well.

The pressurization data measured at these wells (Table 9) verified that a direct linkage occurred between the underground void volumes of the two trenches and that changes in flow rates in the range of 30 to $50 \mathrm{cfm}$ would be adequate to detect significar: changes in pressure at the well head.

\subsubsection{Trench Void Volume by Pressurization Tests}

To determine trench void volume using the pressurization technique, it was necessary to determine the pressure change with time as a constant fiow of air was
-Pressure measured in inches of water at the trop of the monitoring well.
Table 9. Preliminary pressurization data*

\begin{tabular}{|c|c|c|c|c|}
\hline \multirow[t]{2}{*}{ Methor } & \multirow[t]{2}{*}{ Well } & \multicolumn{3}{|c|}{ Flow rate (cfm) } \\
\hline & & 22 & 35 & 67 \\
\hline \multirow{3}{*}{ Single well } & $151-1$ & 0.2 & 0.5 & 1.5 \\
\hline & $151-2 \mathrm{E}$ & 0.3 & 0.6 & 1.5 \\
\hline & $151-3$ & 0.4 & 0.8 & 1.8 \\
\hline \multirow[t]{7}{*}{$151-10$} & $151-5$ & 0.5 & 0.8 & 1.9 \\
\hline & $151-6$ & 0.3 & 0.6 & 1.7 \\
\hline & $151-7$ & 0.4 & 0.8 & 1.8 \\
\hline & $151-8$ & 0.4 & 0.8 & 1.8 \\
\hline & 151.9 & 0.3 & 0.6 & 1.6 \\
\hline & $170-1$ & 0.1 & 0.2 & 0.6 \\
\hline & $170-6$ & 0.3 & 0.4 & 1.2 \\
\hline \multirow{12}{*}{$\begin{array}{c}\text { Single well } \\
170-10\end{array}$} & & \multicolumn{3}{|c|}{ Flow rate $(\mathrm{cfm})$} \\
\hline & & 27 & 42 & 56 \\
\hline & $151-1$ & 0.3 & 0.5 & 1.1 \\
\hline & $151-5$ & 0.6 & 0.8 & 1.4 \\
\hline & 151.7 & 0.5 & 0.7 & 1.4 \\
\hline & $151 \cdot 10$ & 0.3 & 0.6 & 1.2 \\
\hline & $170-1$ & 0.3 & 0.4 & 1.0 \\
\hline & $170 \cdot 2 \mathrm{E}$ & 0.5 & 0.8 & 1.6 \\
\hline & $170 \cdot 3$ & 0.6 & 0.9 & 1.9 \\
\hline & $170-6$ & 0.6 & 0.9 & 1.9 \\
\hline & $170-8$ & 0.5 & 0.8 & 1.4 \\
\hline & $170-12$ & 0.5 & 0.9 & 1.9 \\
\hline \multirow{5}{*}{$\begin{array}{l}\text { Multiple } \\
\text { wells }\end{array}$} & & \multicolumn{3}{|c|}{ Flow rate $(\mathrm{cfm})$} \\
\hline & & 9 & 39 & 56 \\
\hline & $151.2 \mathrm{E}$ & 0.1 & 0.7 & 1.2 \\
\hline & 151.5 & 0.3 & 1.0 & 1.6 \\
\hline & $151-9$ & 0.1 & 0.8 & 1.4 \\
\hline 151.7 & $170-2$ & 0.2 & 0.8 & 1.3 \\
\hline $\begin{array}{c}151-10 \\
170-1\end{array}$ & $170-2 E$ & 0.1 & 0.8 & 1.4 \\
\hline \multirow{2}{*}{$\begin{array}{l}170-10 \\
170-12\end{array}$} & $170-6$ & 0.1 & 0.7 & 1.3 \\
\hline & $170-8$ & 0.2 & 0.6 & 1.0 \\
\hline
\end{tabular}


pumped into the trenches (see Fig. 5). To do this, air was pumped into six injection wells, three in each of the two trenches (one at each end and at the middle of the trenches, wells 151-1, 151-7, and 151-10 and 170-1, 170-10, and 170-12). Pressure was monitored at eight wells, four in each of the two trenches (wells 151-2E, 151-4, 151-5, 151-9, 170-2E, 170-2, 170-6, and 170-12, see Fig. 14).

The gage pressures in trenches 151 and 170 on pressurization at $40,70,100$, and $130 \mathrm{cfm}$ were recorded with respect to time in Figs. 15 through 18. These data were fitted using a nonlinear least-squares regression technique (NLIN procedure of SAS 1985) to the general equation

$$
P_{t g}=P_{c g}\left(1-e^{-B_{1}{ }^{\prime}}\right)
$$

where

$P_{t g}=$ trench gage pressure in inches of water,

$t=$ time in seconds,

$P_{c g}=$ constant gage pressure in trench in inches of water,

$B_{l}=$ is a constant descriptive of the pressure rise in the trench.

The value $B_{l}$ is used to determine net inflow volume $\left(V_{i}\right)$ that was pumped into the trench from which the trench void volume $\left(V_{o}\right)$ can be determined (see Eqs. 6, 7, and 8 in Sect. 2.5.1). Expressed in the following units, the equations take the following form

$$
V_{1}=0.0167 \frac{F_{c}}{B_{1}}
$$

where

$F_{c}=$ constant pump rate in $\mathrm{cfm}$,

$B_{1}=$ coefficient in $\mathrm{s}^{-1}$ (as determined by curve fitting NLIN procedure), $V_{1}=$ net inflow in $\mathrm{ft}^{3}$.

Also,

$$
V_{c}=\frac{0.037 V_{1} P_{c g}+15.1 V_{1}}{P_{c g}}
$$

where

$P_{c g}=$ constant trench gage pressure in inches of water,

$V_{o}=$ trench void volume in $\mathrm{yd}^{3}$.

The calculated trench void volumes and values for $P_{c k}$ and $B_{1}$ are tabulated (Table 10) for each of the flow rates used to determine a pressure rise in the trenches. Calculated trench void volumes varied considerably (range from 229 to $298 \mathrm{yd}^{3}$ ), and all are 
Table 10. Pressurization constants and trench void volumes for four inflow rates used in TARA trench pressurization tests

\begin{tabular}{cccc}
\hline $\begin{array}{c}\text { Flow } \\
\text { rate } \\
(\mathrm{cfm})\end{array}$ & $\begin{array}{c}P_{c g} \\
\text { (inches } \\
\text { of water) }\end{array}$ & $\begin{array}{c}B_{l} \\
\left(\mathrm{~s}^{-1}\right)\end{array}$ & $\begin{array}{c}V_{o} \\
\left(\mathrm{yd}^{3}\right)\end{array}$ \\
\hline 40 & 0.68 & 0.0496 & 298 \\
70 & 1.31 & 0.0478 & 281 \\
100 & 2.38 & 0.0460 & 231 \\
130 & 3.08 & 0.0466 & 229 \\
\hline
\end{tabular}

considerably higher than the $115 \mathrm{yd}^{3}$ determined by water pump-in tests. Air pressurization at 100 and $130 \mathrm{cfm}$ gave very similar void volumes, 231 and $229 \mathrm{yd}^{3}$, respectively.

In both of these data sets (at 100- and 130-cfm flow rates), the data appeared to fit better with the regression equation than it did for 40 - and 70 -cfm tests (see Figs. 15 through 18). Also, the coefficients of variance (\%) for the estimates of $B_{1}$ in the 40 - and 70-cfm pressurization tests were 23 and $14 \%$, respectively, compared with 9.4 and $8.8 \%$ for the 100- and $130-\mathrm{cfm}$ tests. The simple fact that the range in pressure readings at the 100 - and 130 -cfm tests ( 2.4 to 3.0 in. of water) were so much larger than the 40 - to 70 -cfm tests $(<1.3$ in. of water) made it easier to record the pressures as a function to time for the higher flow rates. Thus, the 100 - and 130 -cfm tests probably represent better estimates of the trenches' void volume than do the 40- and 70-cfm tests. It is not clear why the void volume for trenches 151 and 170 determined by the pressurization technique is $\sim 100 \%$ higher $\left(230 \mathrm{yd}^{3}\right)$ than the $115 \mathrm{yd}^{3}$ determined by water pump-in tests. These values expressed in percent void volume are approximately 25 and $49 \%$ (for the water-pumping and air-pressurization tests, respectively). These values are based on a trench depth of $10.4 \mathrm{ft}$ from Table 4 and areas of $583 \mathrm{ft}^{2}$ and $612 \mathrm{ft}^{2}$ for trenches 151 and 170 (a total volume for trenches 151 and 170 of $461 \mathrm{yd}^{3}$ ). However, if one keeps in mind, that both methods involve considerable experimental error and that both are subject to a variety of boundary conditions governed by the conditions of the soil and distribution of pore volumes, the agreement between the two methods may not be so poor.

The void volume determined by the water pump test most likely represents the void volume that could be realistically filled by grout. Also, this test contained a correction for the quantity of water observed in adajent trenches (viz, trenches 148 and 


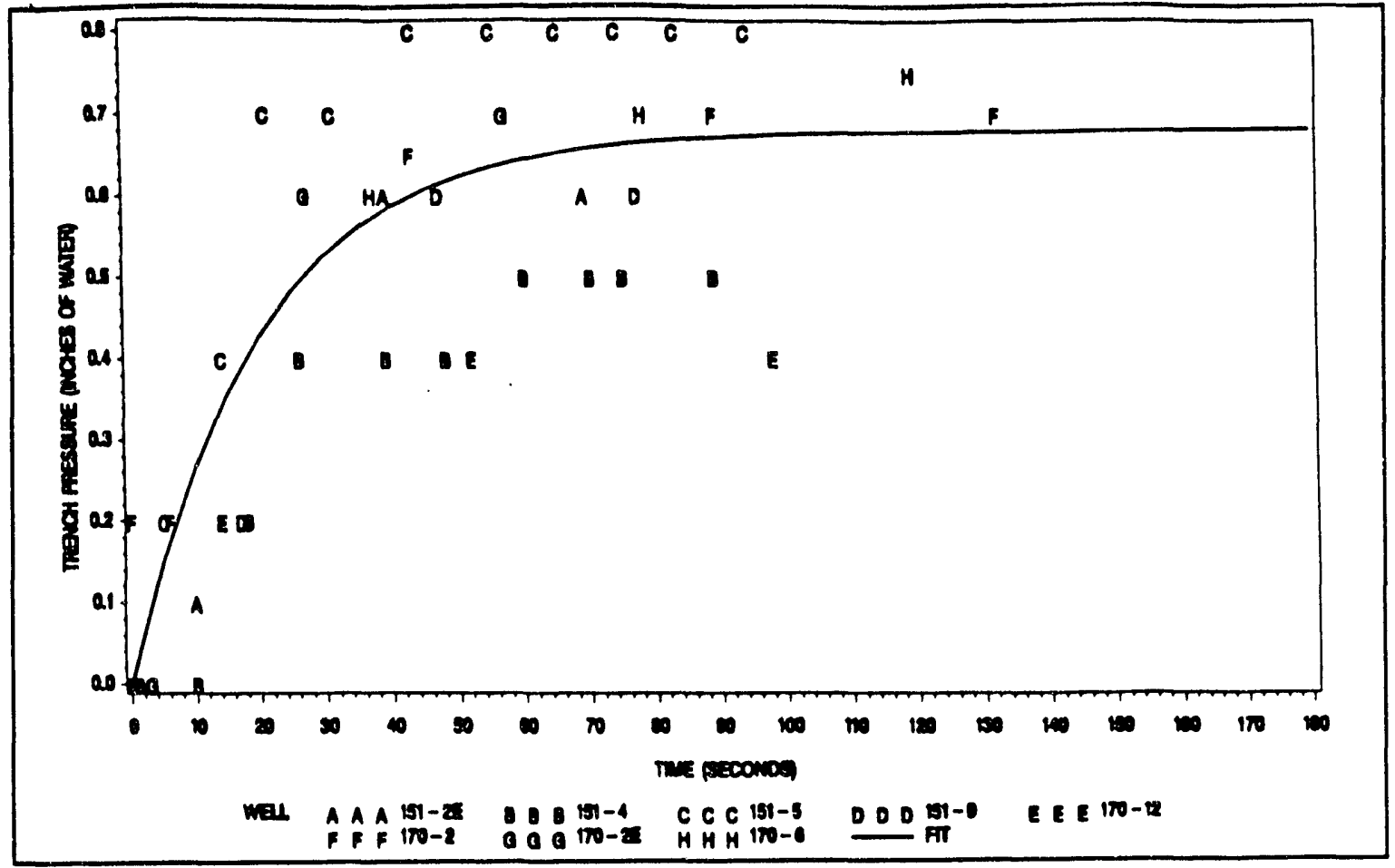

Fig. 15. Pressurization of trenches 151 and 170 at $40 \mathrm{cfm}$.

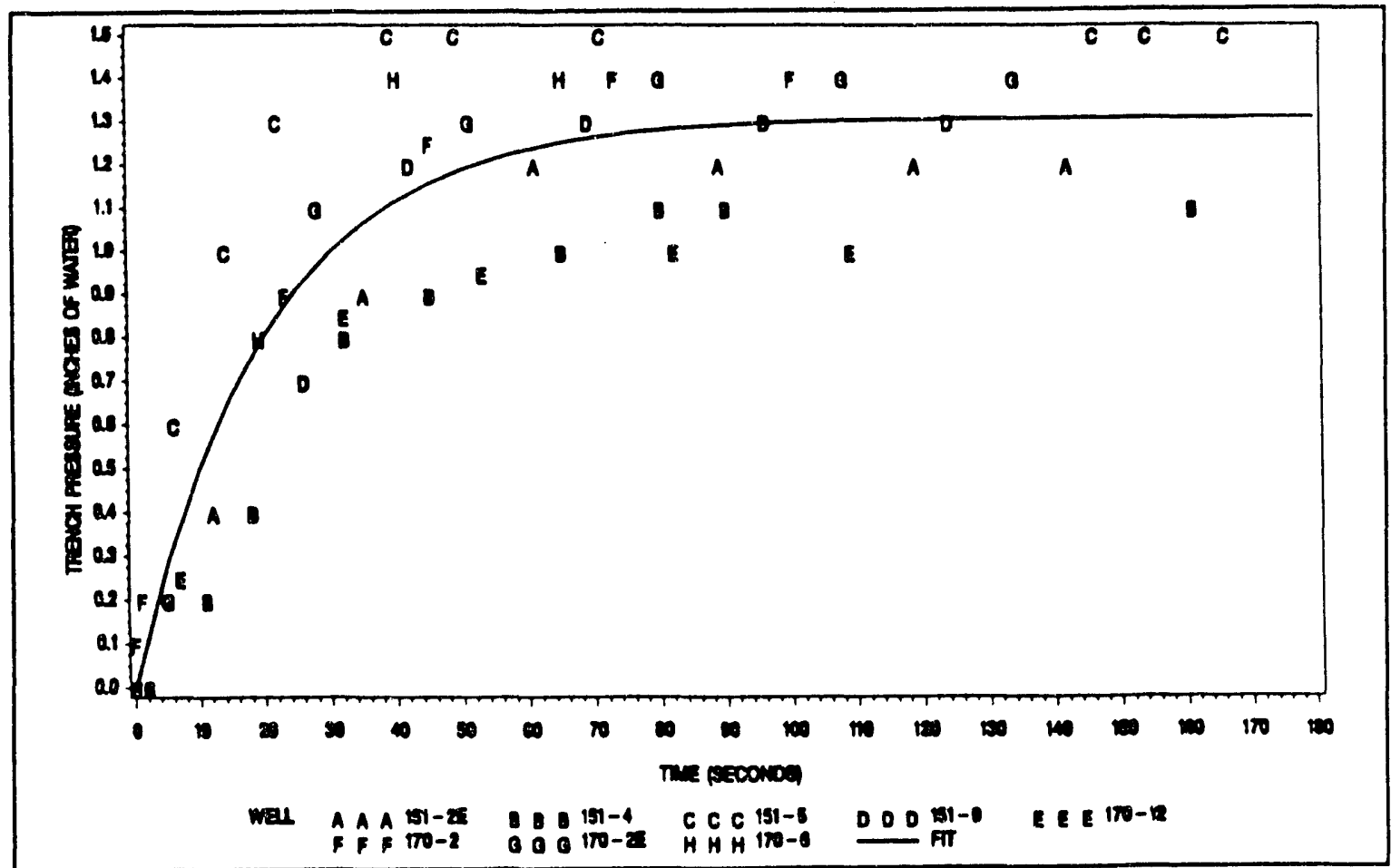

Fig. 16. Pressurization of trenches 151 and 170 at $70 \mathrm{~cm}$. 


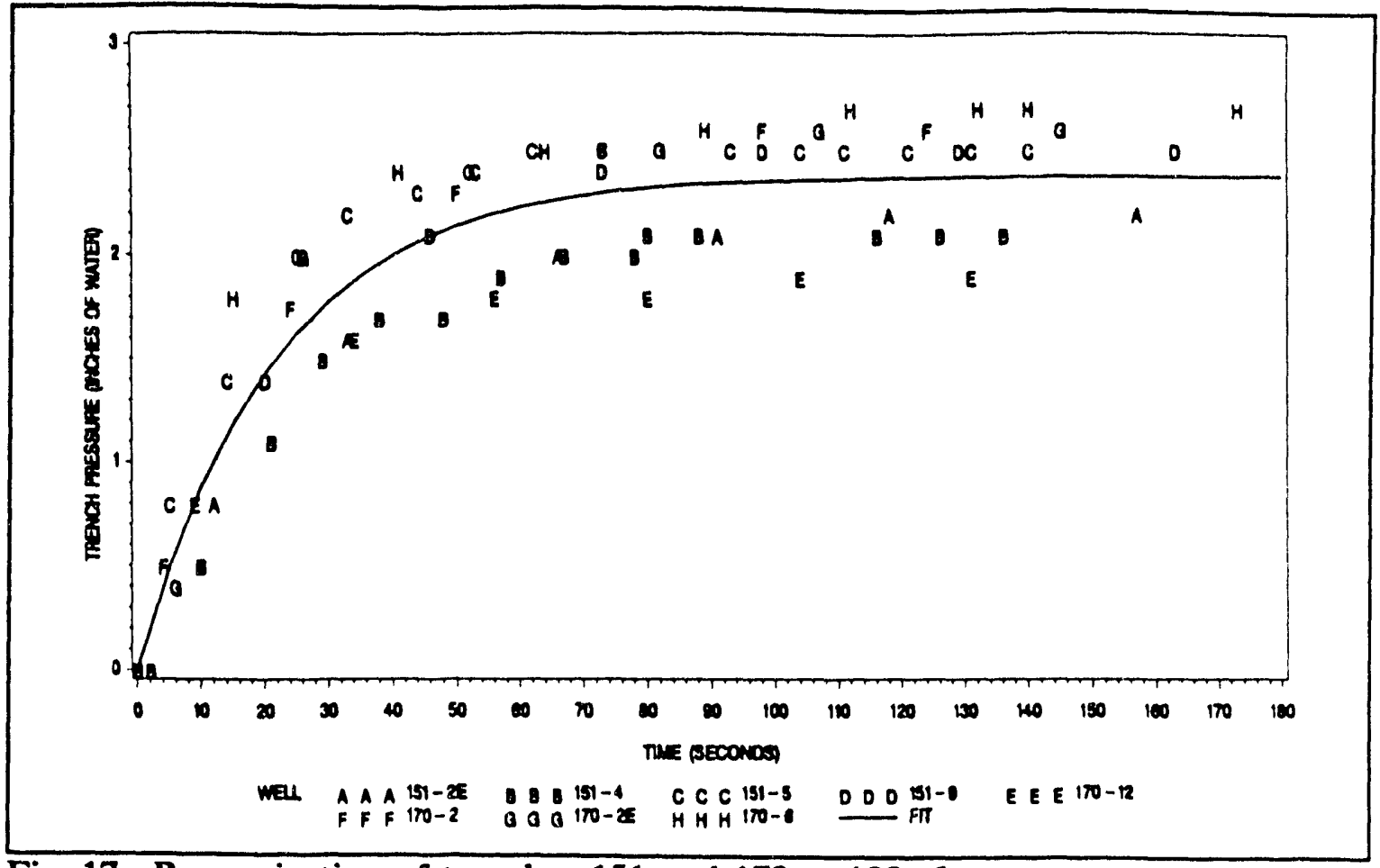

Fig. 17. Pressurization of trenches 151 and 170 at $100 \mathrm{cfm}$.

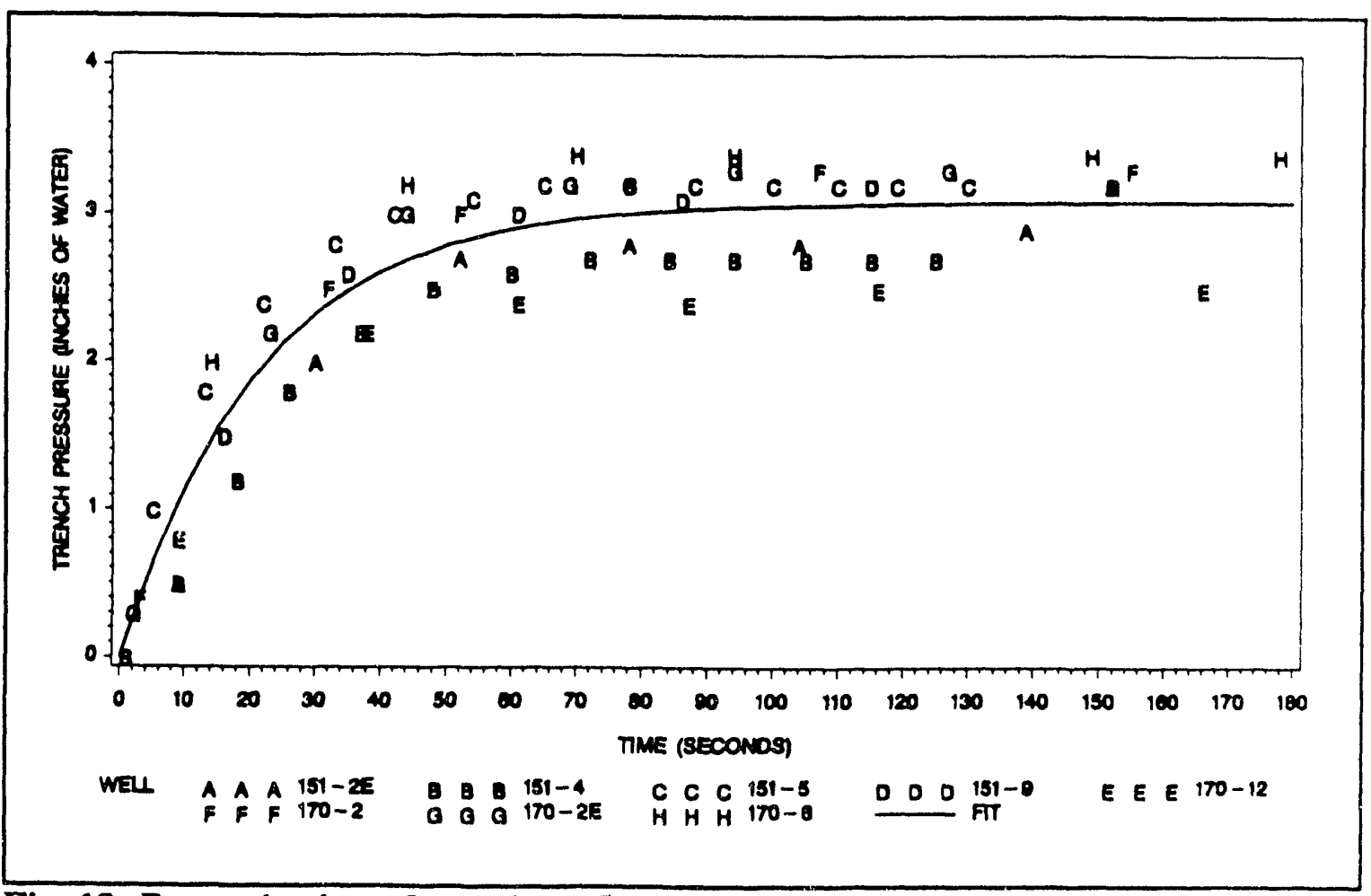

Fig. 18 Pressurization of trenches 151 and 170 at $130 \mathrm{cfm}$. 
159) whereas the pressurization tests did not involve measurements of pressures in the adjacent trenches.

The air pressurization tests assume that pressures in the adjacent trenches were not in the same population as those measured in trenches 151 and 170 (viz, the pressure responses in adjacent trenches would not fit the pressure response curves illustrated in Figs. 15 through 18). Differences in pressures between selected areas within trench 170 and trench 151 were observed when air was injected into a single well of a trench (Table 9). In most of the cases, lower pressures were observed in wells farther from the well where air was injected. Thus, it would be expected that major differences in pressure responses (much lower and likely undetectable) would have been observed in trenches adjacent to those where air was injected making pressure responses as those illustrated in Figs. 15 through 18 unique to trenches 151 and 170.

However, the water pump test did show a connect between trenches 151 and 170 to trenches 148 and 192. The response to trench 148 was rather strong (a $6 \mathrm{ft}$ rise in water level during the pumping stage, see section 2.5.3). Water responses were also observed in trenches 192 and 165. In these cases, minor levels of water were noted in the bottom of the trenches after pumping water into trenches 151 and 170 . Trench 165 was grouted with polyacrylamide prior to air pressurization tests. Thus, during the air pressurization tests, it is possible that there existed a unobstructed connection for air to move freely to trenches 148 and 192 (total trench volume equivalent to $-360 \mathrm{yd}^{3}$ assuming a trench depth of $10.4 \mathrm{ft}$ ). Assuming this to be the case (viz, the pressure response curves for trenches 148 and 192 to be the same as that observed for trenches 151 and 170), then the percent void volume for all four trenches would be $\sim 28 \%$ [230 $\mathrm{yd}^{3} \div$ volume in trenches 151 and $170\left(460 \mathrm{yd}^{3}\right)$ plus the volume in trenches 148 and $192\left(360 \mathrm{yd}^{3}\right)$ ], a value equivalent to that measured by the pumping tests on trenches 151 and 170 (see Table 4).

The difference between the two tests is that the water test is based on the rate of leakage (which is a function of hydraulic head) from the trench compared to the rate of water pumped into the trench. In the air pressurization test, the outflow rate is assumed to be proportional to the pressure differential over time independent the spatial dimensions of the trench. It is also logical that void volume measurements determined by air would generally be greater than void volumes determined by water in that accessibility to the smaller pores (micro- and meso-pores) would be more limited to water than air because of the higher permeability and lower viscocity of air as compared to water. Most importantly, air being a nonwetting fuild does not exhibit a wetting and drying hysteresis as does water.

\subsubsection{Postgrouting Pressurization Tests}

Postgrouting pressurization tests were conducted to determine (1) if intervoid 
linkage between the two trenches remained after grouting and (2) if sufficient void space remained, could its volume be estimated using the pressurization technique. To do this, wells constructed from the postgrouting soil-penetration tests (Table 2) were used for air-injection and air-pressurization readings. The location of these wells within the trench area is illustrated in Fig. 19.

To evaluate the extent of intervoid linkage within and between the two trenches, compressed air was injected into a well at the far end of either of the two trenches, namely, well P-6 in trench 170 and well P-16 in trench 151 (Fig. 19). Equilibrium pressure readings at the other wells throughout the two trenches and outside the trenches were then recorded at a specific flow rate of air (Tables 11 and 12). Pressures measured at the monitoring wells appear to vary inversely with the distance from the point of injection (i.e., the farther the distance from the injection well the lower the pressure). The mean pressure observed in trench 170 when air was injected in well P-16 of trench 151 was $<0.7$ in. of water as compared with $>10$ in. of water at the well adjacent the injection well. A similar relationship held true in trench 151 (mean pressure of 0.26 in. of water) when air was injected in well P-2 of trench 170 . However, this phenomenon was not as apparent in pregrouting pressurization tests (see Table 9). For example, the mean pressure difference between the injection trench and adjacent trench was $\sim 0.5 \mathrm{in}$. of water and was not appreciably different from the variation in pressures

Table 11. Trench pressures developed by injecting air into well P-16 of trench 151

\begin{tabular}{lccccc}
\hline \multicolumn{2}{c}{ Trench 151 } & \multicolumn{2}{c}{ Trench 170 } & \multicolumn{2}{c}{ Outside Trenches } \\
Well & Pressure & Well & Pressure & Well & Pressure \\
\hline P-14 & $>10$ & P-2 & 0.2 & P-1 & 0.0 \\
P-15 & 8.3 & P-3 & 0.4 & P-12 & 0.2 \\
P-17 & 4.0 & P-4 & 0.4 & $151-$ W & 0.0 \\
P-18 & 3.1 & P-5 & 0.1 & $151-$ SW & 0.1 \\
P-19 & 4.0 & P-6 & 0.6 & $151-$ E & 0.0 \\
P-20 & 1.9 & P-7 & 0.3 & $151-\mathrm{S}$ & 0.2 \\
P-21 & 2.5 & P-8 & 1.0 & $170-$ NW & 0.0 \\
P-22 & 1.8 & P-9 & 0.6 & $165-S W$ & 0.1 \\
P-23 & 1.8 & P-10 & 1.2 & & \\
P-24 & 1.7 & P-11 & 1.7 & & \\
P-25 & 1.8 & & & & \\
\hline \hline
\end{tabular}

-Flow rate of $90 \mathrm{f}^{3} / \mathrm{min}$ and pressure measured in inches of water at the top of the monitoring well. 
Table 12. Trench pressures developed by injecting air into well P-2 of trench 170

\begin{tabular}{|c|c|c|c|c|c|}
\hline \multicolumn{2}{|c|}{ Trench 170} & \multicolumn{2}{|c|}{ Trench 151} & \multicolumn{2}{|c|}{ Outside Trenches } \\
\hline Well & Pressure" & Well & Pressure & Well & Presoure \\
\hline P-3 & $>10$ & P-14 & 0.0 & P-1 & 0.9 \\
\hline$P-4$ & 7.8 & P.15 & 0.0 & $165-\mathrm{NW}$ & 2.5 \\
\hline P-5 & 5.3 & P.16 & 0.2 & $151-\mathrm{w}$ & 0.0 \\
\hline$P-6$ & 7.1 & P-17 & 0.2 & $151 . S W$ & 0.1 \\
\hline P.7 & 6.5 & P-18 & 0.3 & $151-\mathrm{E}$ & 0.0 \\
\hline P-8 & 3.0 & P-19 & 0.2 & $165-\mathrm{SW}$ & 0.1 \\
\hline P-9 & 2.5 & P.20 & 0.3 & & \\
\hline P-10 & 2.8 & P-21 & 0.3 & & \\
\hline \multirow[t]{4}{*}{ P-11 } & 0.6 & P.22 & 0.4 & & \\
\hline & & P-23 & 0.3 & & \\
\hline & & P.24 & 0.7 & & \\
\hline & & P.25 & 0.2 & & \\
\hline
\end{tabular}

-Flow rate of $100 \mathrm{At} / \mathrm{min}$ and preseure measured in inches of water at the top of the monitoring well.

within a trench. These data support the conclusion that little resistance existed in the flow of air within and between trenches 151 and 170 (highly permeable large void spaces) in the pregrouted trenches; thus, the two trenches respond as a single trench. Grouting appears to have greatly decreased permeability by filling the large voids; however, significant channeling within and between trenches still remains.

An estimate of the void volume remaining in the two trenches after grouting was attempted using the pressurization technique (see Sect. 2.5.1, Trench Pressurization-Theory). To determine void volume of both trenches (151 and 170), air was simultaneously injected into wells P-2, P-7, and P-11 of trench 170 and wells P-14, $\mathrm{P}-21$, and $\mathrm{P}-25$ of trench 151 (Fig. 19). Pressure responses as a function of time were recorded at the other wells at 110 and $155 \mathrm{cfm}$ (see Figs. 20 and 21). To determine void volume within individual trenches (e.g. air was pumped into trench 151 through wells P-14, P-21, and P-25 at a flow rate of $115 \mathrm{cfm}$ ). For trench 170, air was pumped into wells P-2, P-7, and P-11 at a flow rate of $105 \mathrm{cfm}$. Pressure responses were then recorded as a function of time at the other wells (Figs. 22 and 23). Void volumes for these trenches were determined using Eqs. (16) and (17) (Table 13).

A much shorter response time and larger variation in pressures were recorded at the wells of postgrouted trenches than at pregrouted trenches (e.g., compare pressure-response curves of Figs. 15 through 18 with those observed in Figs. 20 
through 23). This probably results from the much larger resistance of flow in postgrouted trenches versus pregrouted trenches. The pressure response curves measured in pregrouted trenches closely simulated those of a closed vessel (a single curve regardless of the location measured), the theory on which the technique is based. For example, the pressurization data from the pregrouted tests could be fitted using nonlinear regression procedures with confidence (i.e., coefficients of variance for estimates of $B_{t}$ were $<10 \%$ at flow rates $>100 \mathrm{cfm}$ ). For pustgrouted trenches this was not the case (i.e., coefficients of variance for estimates of $B_{l}$ ranged from 10 to $28 \%$ ). On the other hand, coefficients of variance for estimates of $P_{c g}$ were $<5 \%$. Estimates of total trench void volume (trenches 151 and 170 combined) were 87 and $71 \mathrm{yd}^{3}$, using 110 and 155 $\mathrm{cfm}$ flow rates, respectively. Estimates of individual trench void volumes were 37 and $43 \mathrm{yd}^{3}$ for trenches 151 and 170 , respectively. Thus, the estimate of total trench volume determined by two different flow rates and combined volume determined for each trench independently is on the order of $80 \mathrm{yd}^{3}$. The total trench volume before grouting was estimated to be $230 \mathrm{yd}^{3}$ (Table 10). Approximately $79 \mathrm{yd}^{3}$ of grout was added to the trenches, leaving on the order of $70 \mathrm{yd}^{3}$ of trench volume still available, theoretically. However, it is entirely possible that grouting restricted air movement to this $70 \mathrm{yd}^{3}$ that is encapsulated or adjacent to the sides or bottom of the trenches.

\subsection{TRENCH GROUTING}

Grouting of trench 170 was started on June 26, 1990, and finished on June 29 , 1990. Grouting of trench 151 occurred $\sim 1$ week later, July 7 through July 12, 1990.

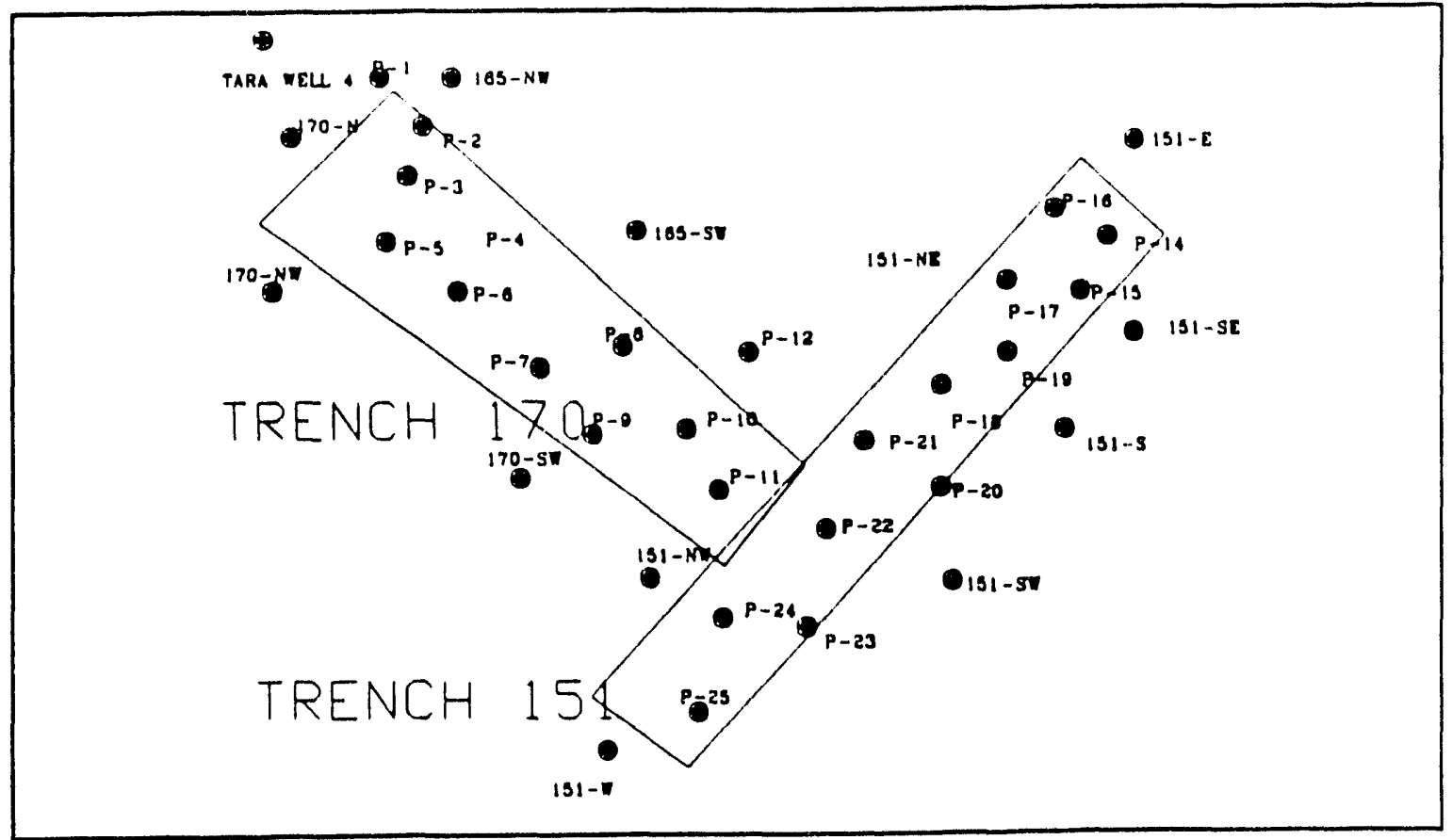

Fig. 19. Location of wells used for post-grouting pressurization tests. 


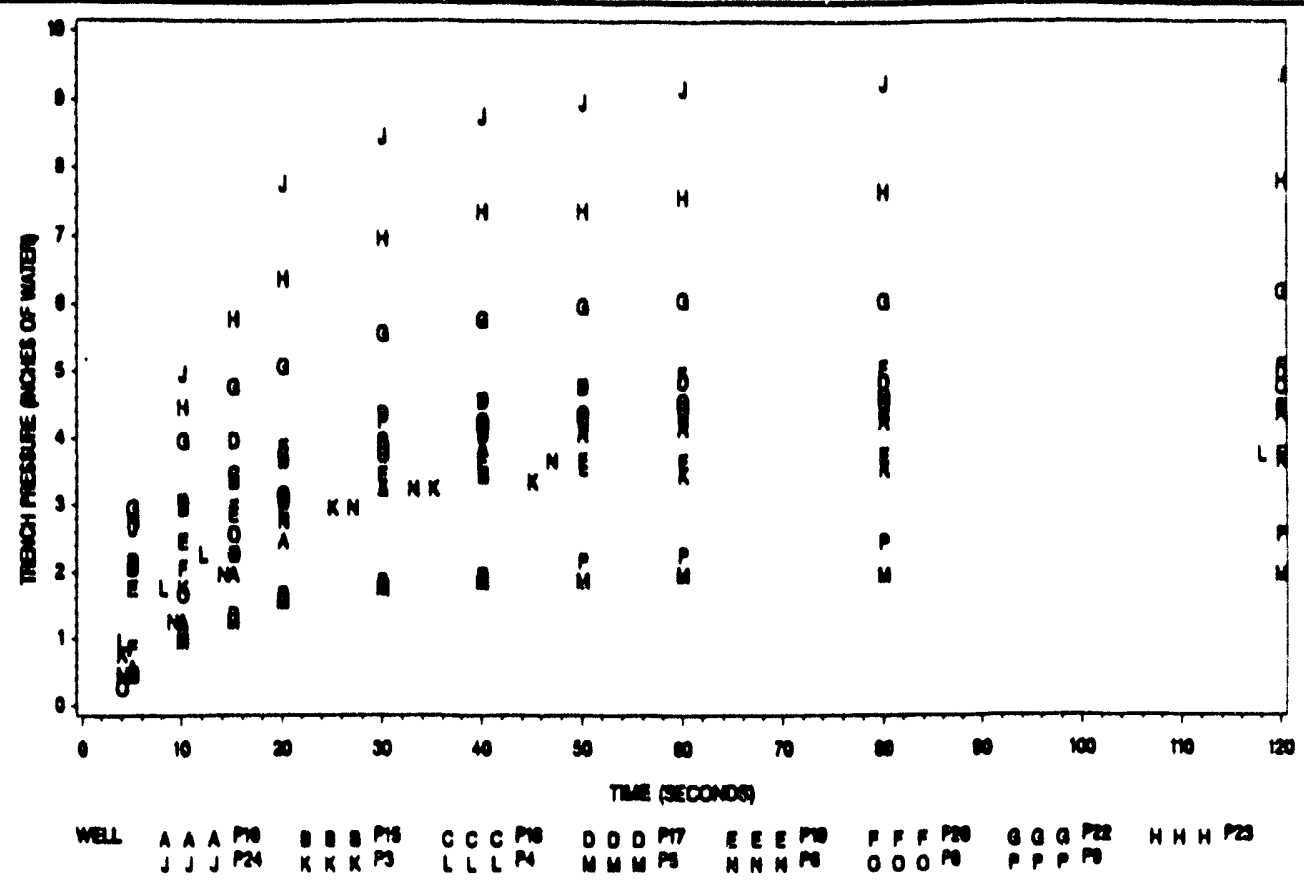

Fig. 20. Pressurization of postgrouted trenches 151 and 170 at a flow rate of $110 \mathrm{~cm}$.

Grout solids were dry-blended at the New Hydrofracture Facility, mixed with water in

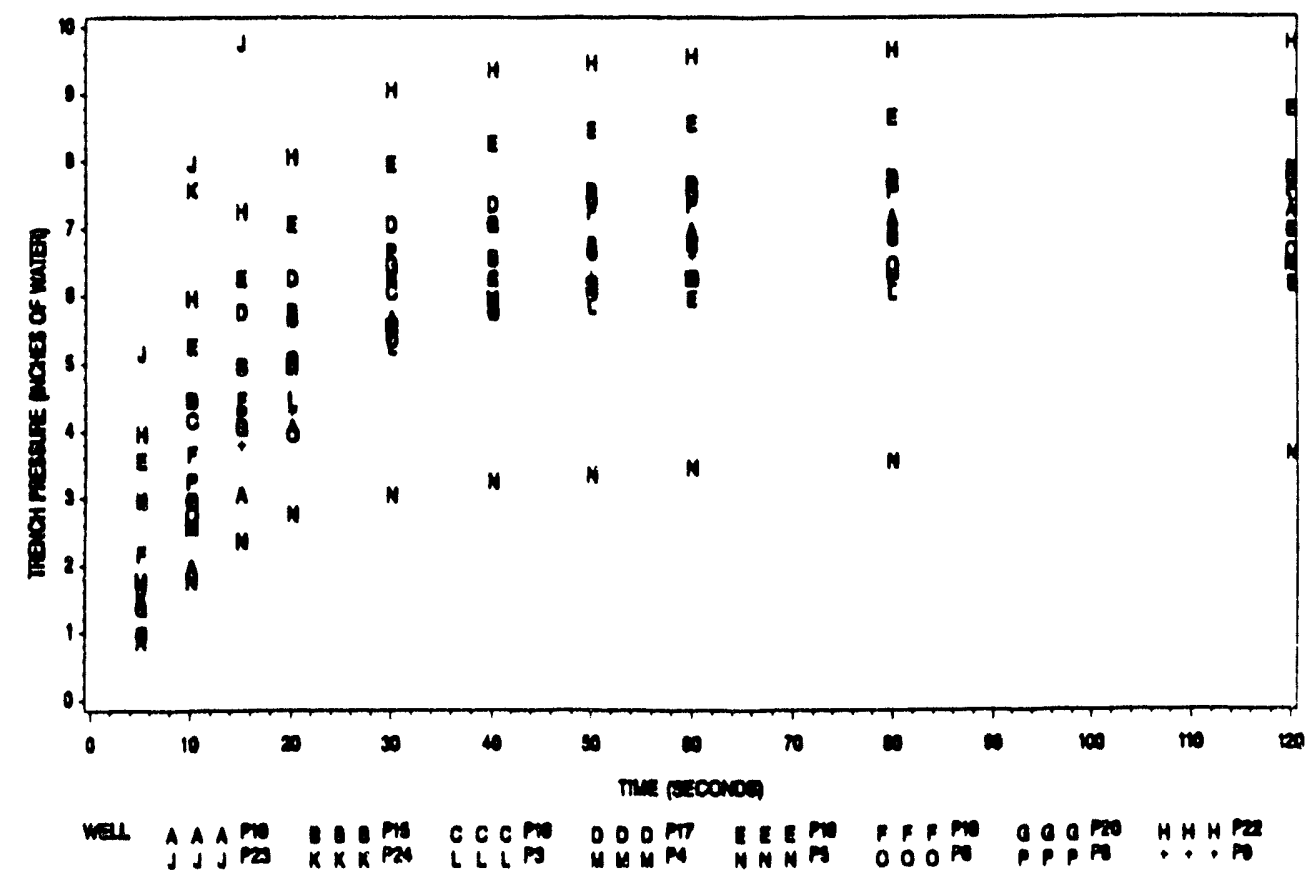

Fig. 21. Pressurization of postgrouted trenches 151 and 170 at a flow rate of $155 \mathrm{cfm}$. 


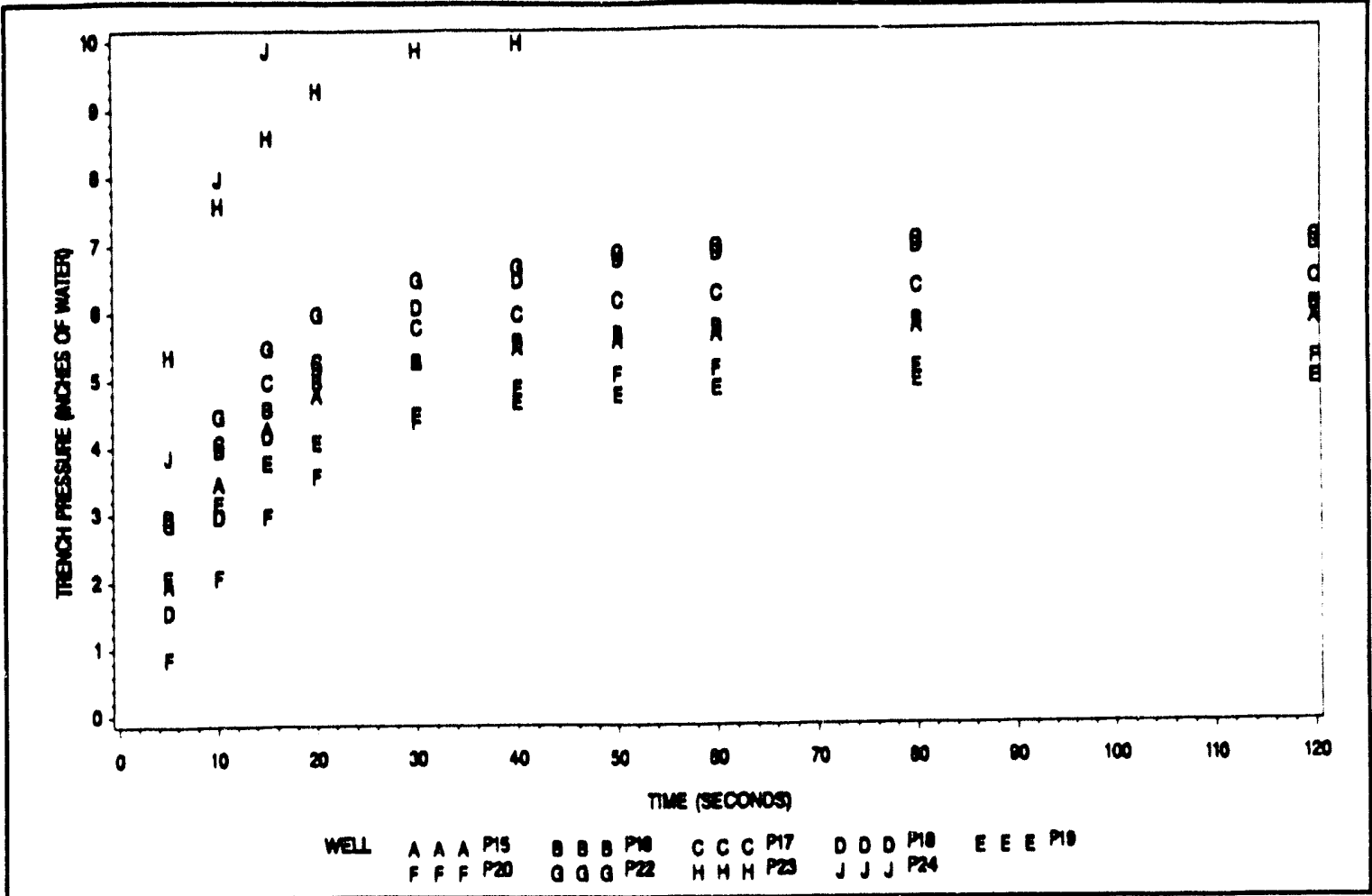

Fig. 22. Pressure response in postgrouted trench 151 at a flow rate of $115 \mathrm{cfm}$.

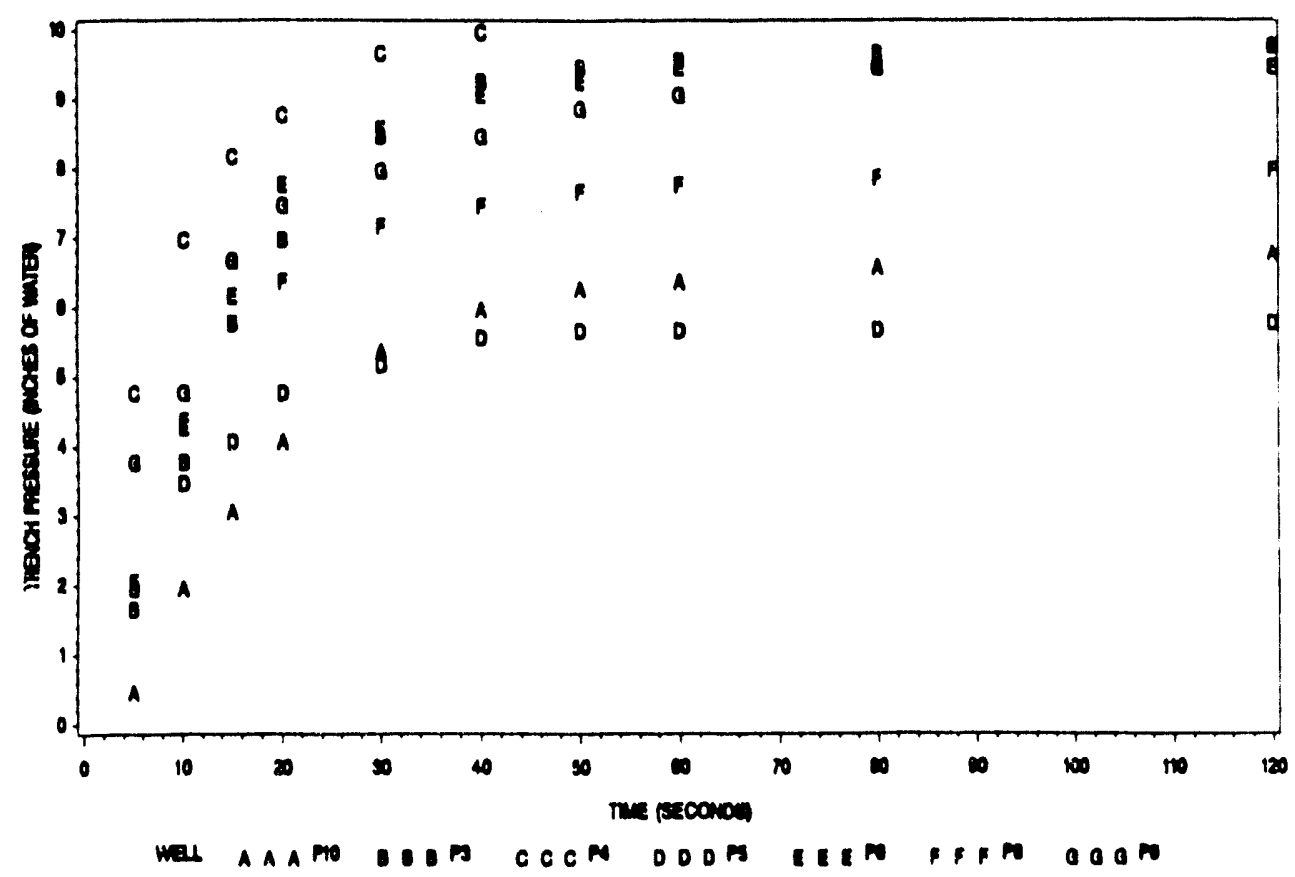

Fig. 23. Pressure response in post-grouted trench 170 at a flow rate of $105 \mathrm{cfm}$. 
Table 13. Postgrouted trench void volumes estimated by the pressurization technique

\begin{tabular}{ccccc}
\hline Trench & $\begin{array}{c}\text { Flow rale } \\
\text { (cfm) }\end{array}$ & $\begin{array}{c}P_{q_{4}} \\
\text { (inches of water) }\end{array}$ & $\begin{array}{c}\mathrm{B}_{1} \\
\left(8^{-1}\right)\end{array}$ & $\begin{array}{c}\mathrm{V}_{\mathrm{o}} \\
\left(\mathrm{yd}^{3}\right)\end{array}$ \\
\hline $151 \& 170$ & 110 & 4.74 & 0.0683 & 87 \\
$151 \& 170$ & 155 & 6.96 & 0.081 & 71 \\
151 & 115 & 6.07 & 0.129 & 37 \\
170 & 105 & 8.25 & 0.072 & 43 \\
\hline
\end{tabular}

a redi-mix concrete truck, and transported to SWSA 6. Each truckload contained 7.7 $\mathrm{yd}^{3}$ (see Sect. 2.8). The grout injection operation proceeded rather smoothly. The single most troublesome operational problem was the plugging of the delivery lines from the grout pump. The plugging most often occurred at the reducer, coupling the 2-in.-diam pipe from the grout pump to the 1-in.-diam high pressure hose used to delivery the grout to the slotted injection wells. Small gravel $(0.25$ to 0.5 in. diam), probably introduced from the redi-mix truck or chips of dried grout from the mixing tanks initiated the plugging. The line at the reducer couple had to be disconnected and cleaned periodically for continued operation. A summary of the grouting operation for trenches 170 and 151 is outlined in Tables 14 and 15.

One of the problems observed by Tamura et al. (1987) in the grouting of trench 150 in SWSA 6 was leakage or backflow of grout between the lance used to inject grout and the soil. They had used a lance made of 2 -in.-diam Schedule 80 steel pipe to inject grout. Unlike the injection wells used in this study, the lance did not have slotted openings to deliver grout. The lance depth was changed by pulling the lance up $1 \mathrm{ft}$ when the grouting pressure exceeded 20 psi or flow rates became $<4 \mathrm{gpm}$. This weakened the seal between the lance and surrounding soil, often resulting in backflow of grout outside and along the lane to the soil surface.

In this study, to ensure that the injected grout did not return to the surface along the pipe/soil interphase, a 1-ft section of 2-in.-diam pipe was placed over the 1.25 -in.-diam injection well and driven into the ground to $\sim 3$ in. below the soil surface. A cement-based grout collar was then molded around the surface of the well/soil interphase. Injection pressures used in this study were significantly greater (maximum pressure as high as 75 psi), yet breakthrough around an injection well occurred only once (well 8 in trench 151). 
A total volume of $79 \mathrm{yd}^{3}$ of grout was injected into the two trenches (48 and $31 \mathrm{yd}^{3}$ in trenches 151 and 170 , respectively). If one assumes the void volume to be $230 \mathrm{yd}^{3}$ as determined by the air pressization tests (Table 10 ), then $34 \%$ of the available void volume was filled with grout. However, if $115 \mathrm{yd}^{3}$ is taken as the void volume, as determined from water-pump test, then $68 \%$ of the void volume was filled with grout.

Trench 170 is the larger of the two trenches, but more grout was injected into trench 151. Assuming the trenches to have an overall depth of 10.4 (as measured by the water pump test, Table 4), the volume of the trenches are 236 and $225 \mathrm{yd}^{3}$, respectively. In this respect, $\sim 17 \%$ of the total volume was filled with grout ( $21 \%$ for trench 151 and $13 \%$ for trench 170 ).

Tamura et al. (1987) injected $40 \mathrm{yd}^{3}$ into a much smaller trench (Trench 150, measuring $56 \times 9.2 \times 11.8 \mathrm{ft}$ ) whose volume, assuming a $3 \mathrm{ft}$ soil cover, was $152 \mathrm{yd}^{3}$. On the bases of these measurements, the volume of grout injected would constitute $26 \%$ of the trench. However, the final disposition of some of this grout was outside the trench because the breakthrough of grout to the surface was recorded at six to eight areas outside the trench. Also, the quantity of injected grout represented 109\% of the measured void volume, indicating the volume of grout injected to be a high estimate. Most important, the void volume available for grouting is dependent on the waste

Table 14. Operational description of grouting trench $\mathbf{1 7 0}$

\begin{tabular}{|c|c|c|c|c|}
\hline Date & Time & Truck & Well & Comments \\
\hline $6 / 26$ & p.m. & 1 & $1 \& 2$ & $\begin{array}{l}\text { When well pressure reached } 50 \text { psi, moved to well } 2 \text { and } \\
\text { pumped remainder of load }\end{array}$ \\
\hline $6 / 27$ & p.m. & 2 & $3 \& 12$ & $\begin{array}{l}\text { At } 1 \text { p.m. starting pumping into well } 3 \text {. After } 15 \mathrm{~min} \text {, } \\
\text { pressure was }>50 \text { psi. Moved to well } 12 \text { and pumped } \\
\text { remainder of load }\end{array}$ \\
\hline $6 / 28$ & $\mathbf{a} \cdot \mathbf{m}$ & 3 & 6 & $\begin{array}{l}\text { Started pumping into well } 6 \text { a } 10: 45 \text { a.m.. Finished } \\
\text { pumping entire load into well } 6 \text { at } 12: 10 \text { p.m. }\end{array}$ \\
\hline $6 / 28$ & p.m. & 4 & $\begin{array}{l}6,2, \& \\
8\end{array}$ & $\begin{array}{l}\text { Started pumping into well } 6 \text { at } 3: 15 \text { p.m. After } 15 \text { min, } \\
\text { pressure was }>75 \text { psi. Moved to well } 7 \text { and at } 4: 20 \text { p.m. } \\
\text { grout began to fow out of the top of well } 8 \text {. Pressure in } \\
\text { well } 7 \text { was } ~-50 \text { psi. Returned to well } 6 \text { and started } \\
\text { pumping. At } 4: 50 \text { p.m. started pumping into well } 8 \text {. At } \\
5: 00 \text { p.m. stopped pumping into well } 8 \text { (pressure }>50 \\
\text { psi). Wasted } 1.7 \text { yd to waste basin }\end{array}$ \\
\hline $6 / 29$ & a.m. & 5 & $10 \& 11$ & $\begin{array}{l}\text { Started pumping into well } 11 \text { at } 9: 37 \text { a.m.. Pumped } 5-10 \\
\text { min and got breakthrough at ground surface. Connected to } \\
\text { well } 10 \text { and pumped }-5 \mathrm{~min} \text {. Pressure built up to } 70 \mathrm{psi} \\
\text { and then stopped grouting. Estimated } 2 \mathrm{yd}^{2} \text { pumped } \\
\text { (wasted remainder of load to waste basin) }\end{array}$ \\
\hline
\end{tabular}


Table 15. Operational description of grouting trench 151

\begin{tabular}{|c|c|c|c|c|}
\hline Date & Time & Truck & Well & Comments \\
\hline $7 / 9$ & a.m. & 6 & $1,3, \&$ & $\begin{array}{l}\text { Checked bottom of well } 8 \text { for grout from filling of trench } \\
170 \text {. No sign of grout; thus, no evidence of grout } \\
\text { movement from trench 170 to trench 151. Started } \\
\text { pumping into well } 1 \text { at 10:00 a.m.. At 10:30 a.m., started } \\
\text { pumping into well } 3 \text { (could not pump into well } 2 \text { because } \\
\text { of broken well cap). At 11:00 a.m., detected grout at } \\
\text { bottom of well } 2 \text {. At noon, started pumping into well } 4 \text {. } \\
\text { Finished load into well } 4\end{array}$ \\
\hline $7 / 10$ & a.m. & 7 & $\frac{2,4 . \&}{5}$ & $\begin{array}{l}\text { At } 9 \text { a.m., well } 5 \text { had }-3 \text { th of grout at bottom of well } \\
\text { (from well 4). Well } 6 \text { did not contain grout at bottom of } \\
\text { well. At } 9: 47 \text { a.m., started rumping load } 7 \text { into well } 2 \\
\text { (well cap repaired for pumping). At 10:16 a.m., well } 5 \\
\text { had }-5 \text { ft of grout on bottom of trench. However, well } 6 \\
\text { did not have grout at bottom. At 10:22 a.m., pressure at } \\
\text { well } 2 \text { was }>50 \text { psi; thus, moved to well } 4 \text {. Pressure } \\
\text { immediately went to }>60 \text { psi (possibly plugged from } \\
\text { yesterday's grouting!). Moved to well } 5 \text { and finished load }\end{array}$ \\
\hline $7 / 10$ & p.m. & 8 & 5 & $\begin{array}{l}\text { Started pumping into well } 5 \text { at } 1: 05 \text { p.m. At } 1: 32 \text { p.m. } \\
\text { pressure at well } 5 \text { was }<5 \text { psi. Pumped entire load into } \\
\text { well } 5 \text {. At } 1: 12 \text { p.m. there was no grout at bottom of well } \\
6 \text {, but well } 7 \text { had }-1.5 \mathrm{ft} \text {. At } 1: 27 \text { p.m. wells } 8 \text { and } 9 \\
\text { had } 1.5 \text { and } 0.5 \text { th of grout, respectively. However, no } \\
\text { grout was observed in bottom of well } 10 \text { at this time }\end{array}$ \\
\hline $7 / 11$ & a.m. & 9 & $5 \& 6$ & $\begin{array}{l}\text { Started pumping into well } 5 \text { at } 9: 22 \text { a.m. At } 9: 42 \text { a.m. } \\
\text { pressure at well } 5>50 \text { psi and then moved to well } 6 \text {. At } \\
10: 29 \text { p.m., completed load } 9 \text { (pressure at well } 6 \text { was still } \\
<10 \text { psi) }\end{array}$ \\
\hline $7 / 11$ & p.m. & 10 & $6 \& 7$ & $\begin{array}{l}\text { Started pumping into well } 6 \text { at } 1: 42 \text { p.m. Moved to well } 7 \\
\text { at } 2: 25 \text { p.m. . Load emptied at } 2: 42 \text { p.m. (pressure at well } \\
7 \text { was } 5-10 \text { psi) }\end{array}$ \\
\hline $7 / 12$ & a.m. & 11 & $\begin{array}{c}7,8, \& \\
9\end{array}$ & $\begin{array}{l}\text { Started pumping into well } 7 \text { at } 9: 56 \text { a.m.. At } 10: 12 \text { a.m., } \\
\text { grout broke through the ground surface }-5 \text { ft north of } \\
\text { well. Moved to well } 8 \text { (10:15 a.m.) and pumped until } \\
\text { 10:58 8.m. When grout started coming up . ound well } 8 \text { 's } \\
\text { casing. Pumped remainder of load into well } 9\end{array}$ \\
\hline $7 / 12$ & p.m. & 12 & $9 \& 10$ & $\begin{array}{l}\text { At } 1: 35 \text { p.m., started pumping into well } 9 \text {. At 1:42 p.m., } \\
\text { grout broke through the ground surface. Moved to well } 10 \\
\text { where pumping was continued for } 5 \text { min. after which more } \\
\text { grout came to the surface. A one to two sq yard area of } \\
\text { soil was lifted until it cracked releasing grout to the } \\
\text { surface. About } 2 \text { yd }^{3} \text { was injected, the remainder of load } \\
12 \text { was pumped to the waste basin }\end{array}$ \\
\hline
\end{tabular}


disposed of in the trench, which is quite variable from trench to trench within SWSA 6.

\subsection{GROUNDWATER MONITORING RESULTS}

Sampling of groundwater was very limited because of the site's elevated position above groundwater. The only wells found to contain water were wells $165-\mathrm{NW}$ and 165-SW; however, a routine monitoring program (i.e., weekly or monthly sampling) was not instigated. Tamura et al. (1987) observed that ${ }^{90} \mathrm{Sr}$ concentrations in trench leachate sampled from trench 150 decreased significantly (from $>20,000$ to $<100 \mathrm{~Bq} / \mathrm{L}$ ) after grouting with the same cement-based grout. The $\mathrm{pH}$ of trench leachate was increased from values $<7$ to values $>9.5$, presumably because of the elevated levels of sodium. No pregrouting levels of sodium were available for trench 150 leachate. However, concentrations of sodium in trench leachate of the adjacent trench (trench 152) were $<5 \mathrm{mg} / \mathrm{L}$ compared with sodium concentrations ranging from 50 to $130 \mathrm{mg} / \mathrm{L}$ in leachate sampled from trench 150 after grouting. These results strongly imply that sodium concentrations were greatly increased by grouting with a cement-based grout. Concentrations of calcium and magnesium in leachate from trench 150 after grouting were also much lower than concentrations in leachate from an ungrouted adjacent trench. This suggests that as sodium concentrations rose, calcium and magnesium concentrations were lowered by grouting with a cement-based grout.

Water sampled from 165-NW and 165-SW wells outside the trench area contained higher levels of radioactivity (gross-alpha, gross-beta, and ${ }^{90} \mathrm{Sr}$ ) after grouting (sampled in February 1991) compared with before grouting (sampled in June 1990). The greatest difference was in the concentrations of gross-beta activity, levels between 1 and $2 \mathrm{~Bq} / \mathrm{L}$ before grouting as compared with 7 and 10 after grouting (Table 16). Strontium-90

Table 16. Radioactivity in water sampled from wells $165-\mathrm{NW}$ and $165-\mathrm{SW}$ before and after grouting

\begin{tabular}{ccccc}
\hline \hline Radioactivity & \multicolumn{2}{c}{ Before Grouting } & \multicolumn{2}{c}{ After Grouting } \\
$(\mathrm{Bq} / \mathrm{L})$ & Well & Well & Well & Well \\
& $165-\mathrm{NW}$ & $165-\mathrm{SW}$ & $165-\mathrm{NW}$ & $165-\mathrm{SW}$ \\
\hline Gross alpha & 0.27 & 0.10 & 0.23 & 0.20 \\
Gross beta & 1.1 & 1.7 & 9.6 & 7.0 \\
${ }^{90} \mathrm{Sr}$ & 0.63 & 0.62 & 1.2 & 1.3 \\
\hline \hline
\end{tabular}


concentrations were also higher in water sampled after grouting, but levels of gross alpha remained unchanged. If the character of groundwater were to be significantly changed as a result of grouting with a cement-based grout, levels of sodium would be expected to be elevated as the bleed water or leachate from the alkali-based grout came in contact with the groundwater. However, concentrations of sodium in water sampled from these wells after grouting were similar to those found in water before grouting (Table 17). Also, unlike ${ }^{90} \mathrm{Sr}$ concentrations, the levels of $\mathrm{Ca}, \mathrm{Mg}$, and $\mathrm{Sr}$ were similar in water sampled before versus after grouting. The major difference in water quality before versus after grouting appears to be in levels of $\mathrm{Al}, \mathrm{Fe}, \mathrm{Ni}$, and $\mathrm{Zn}$. Concentrations of all of these metals were elevated in water sampled after grouting. Elevated concentrations of these metals are probably the result of increased reducing conditions in the groundwater during February (cool and wet) compared with conditions in the groundwater during June rather than any influence of grouting per se. 
Table 17. Concentrations of metals $(\mathrm{mg} / \mathrm{L})$ in water

\begin{tabular}{|c|c|c|c|c|}
\hline & \multicolumn{2}{|c|}{ Before Grouting } & \multicolumn{2}{|c|}{ After Grouting } \\
\hline & $\begin{array}{c}\text { Well } \\
\text { 165-NW }\end{array}$ & $\begin{array}{c}\text { Well } \\
165-s w\end{array}$ & $\begin{array}{l}\text { Well } \\
\text { 165-NW }\end{array}$ & $\begin{array}{c}\text { Well } \\
\text { 165-SW }\end{array}$ \\
\hline$A_{8}$ & $<0.005$ & $<0.005$ & $<0.005$ & $<0.005$ \\
\hline $\mathbf{A l}$ & 0.46 & $<0.05$ & 9 & 6.1 \\
\hline As & $<0.05$ & $<0.05$ & $<0.05$ & $<0.05$ \\
\hline $\mathbf{B}$ & $<0.08$ & $<0.08$ & $<0.08$ & $<0.08$ \\
\hline $\mathrm{BC}$ & $<0.0002$ & $<0.0002$ & 0.0019 & 0.001 \\
\hline $\mathrm{Ca}$ & 85 & 46 & 83 & 41 \\
\hline $\mathrm{Cd}$ & $<0.005$ & $<0.005$ & $<0.005$ & $<0.005$ \\
\hline Co & $<0.004$ & $<0.004$ & 0.036 & 0.057 \\
\hline $\mathrm{Cr}$ & 0.007 & 0.005 & 0.025 & 0.019 \\
\hline $\mathrm{Cu}$ & 0.009 & $<0.005$ & 0.022 & 0.017 \\
\hline $\mathbf{F e}$ & 0.49 & 0.089 & 29 & 12 \\
\hline $\mathrm{Li}$ & $<15$ & $<15$ & $<15$ & $<15$ \\
\hline $\mathbf{M}_{\mathbf{8}}$ & 15 & 9.2 & 26 & 12 \\
\hline $\mathbf{M n}$ & 0.097 & 2.2 & 1 & 1.3 \\
\hline Mo & $<0.04$ & $<0.04$ & $<0.04$ & $<0.04$ \\
\hline $\mathrm{Na}$ & 13 & 14 & 10 & 19 \\
\hline $\mathrm{Ni}$ & 0.005 & $<0.005$ & 0.017 & 0.021 \\
\hline $\mathbf{P}$ & $<0.3$ & $<0.3$ & 0.8 & 0.64 \\
\hline $\mathrm{Pb}$ & $<0.05$ & $<0.05$ & 0.44 & $<0.05$ \\
\hline $\mathbf{S b}$ & $<0.05$ & $<0.05$ & $<0.05$ & $<0.05$ \\
\hline Se & $<0.05$ & $<0.05$ & $<0.05$ & $<0.05$ \\
\hline $\mathrm{Si}$ & 13 & 8.8 & 14 & 20 \\
\hline Sn & $<0.05$ & $<0.05$ & 0.051 & $<0.05$ \\
\hline $\mathrm{Sr}$ & 0.2 & 0.089 & 0.22 & 0.091 \\
\hline $\mathrm{Ti}$ & $<0.02$ & $<0.02$ & $<0.02$ & $<0.02$ \\
\hline$v$ & $<0.002$ & $<0.002$ & 0.028 & 0.014 \\
\hline $\mathrm{Zn}$ & 0.019 & 0.006 & 0.15 & 0.21 \\
\hline $\mathbf{Z r}_{\mathbf{r}}$ & $<0.02$ & $<0.02$ & $<0.02$ & $<0.02$ \\
\hline
\end{tabular}




\section{SUMMARY, CONCLUSIONS, AND NEEDS}

A technology being evaluated for use in the closure of one of the low-level radwaste burial grounds at ORNL is trench stabilization using a cement-based grout. To demonstrate the applicability and effectiveness of this technology, two interconnecting trenches in SWSA 6 were selected as candidates for in situ grouting with a particulate grout. The trenches are $\sim 15 \mathrm{ft}$ deep and measure $42 \times 14 \mathrm{ft}$ and $44 \times 14 \mathrm{ft}$. The primary objective was to demonstrate the increased trench stability (characterized by trench penetration tests) and the decreased potential for leachate migration (characterized by hydraulic conductivity tests) following in situ injection of a particulate grout into the waste trenches. Stability against trench subsidence is a critical issue. For example, construction of impermeable covers to seal the trenches will be ineffectual unless subsequent trench subsidence is permanently suspended.

A grout composed of $39 \%$ Type 1 Portland cement, 55.5\% Class F fly ash, and $5.5 \%$ bentonite mixed at $12.5 \mathrm{lb} / \mathrm{gal}$ of water was selected after laboratory testing of several grout formulations. Results of laboratory studies revealed that this formulation exhibited no liquid-to-solid phase separation and a compressive strength of $>900 \mathrm{psi}$ after $28 \mathrm{~d}$. Penetration resistance after $2 \mathrm{~d}$ was $>8000$ psi. Most important, the viscosity of the freshly made grout was $<50 \mathrm{cP}$, allowing it to penetrate and fill intermediate-size trench voids, and the suspension was stable for pumping and injection for up to $8 \mathrm{~h}$.

Before the trenches were grouted, the primary characteristics relating to physical stability, hydraulic conductivity, and void volume of the trenches were determined. Their physical stability was evaluated using soil-penetration tests. Pregrout soil-penetration tests revealed that at depths $>5$ and $<15 \mathrm{ft}$, blows per foot within the trench averaged approximately ten fewer than those outside the trench. These data imply that considerable uncompacted soil and/or void space exists within the trench area which over time will lead to significant subsidence of the upper soil layers. Hydraulic conductivity tests within the trench area also revealed a high potential for the infiltration of water (hydraulic conductivities $>0.1 \mathrm{~cm} / \mathrm{s}$ ).

Void volume within the trenches was determined by two techniques: (1) water-pump tests and (2) a newly developed air-pressurization technique. Estimates of void volume using the air-pressurization technique were $-100 \%$ higher than that determined by the water-pump test $\left(230 \mathrm{yd}^{3}\right.$ compared with $\left.115 \mathrm{yd}^{3}\right)$. It is not clear which of the two techniques is the most accurate because each has theoretical and operational constraints. Void volume estimates from the water-pump test likely represent the void volume available for grouting more than estimates by the air-pressurization technique. The development of the air-pressurization technique was pursued because the water-pump test could result in serious leaching of radionuclides and/or hazardous wastes into groundwater and may induce premature settling of soil overburden into the trench. The water-pump test also leaves soil within the trench near saturation levels for a 
significant time, which could have an influence on solidification of grout introduced into the trench. Consequently, flooding trenches with water is no longer an acceptable practice for determining trench void volume. The air-pressurization method is fast and can be repeated under a variety of pressures and airflows. It is environmentally superior to the water-pump test in that it does not promote the leaching of contaminants to groundwater. The major concern in the use of the air-pressurization technique is that its accuracy has not been validated. More research is needed to demonstrate its accuracy, precision, and its theoretical and operating limitations under controlled conditions .

Soil-penetration tests revealed considerable uncompacted soil or void space within the trench area. For example, at depths $>5$ and $<15 \mathrm{ft}$, blows per foot within the trench averaged $\sim 10$ blows fewer than those outside the trench. After grouting, soil-penetration tests disclosed that stability had been improved greatly. For example, refusal (defined as $>100$ blows to penetrate one foot) was encountered in 17 of the 22 tests conducted within the trench area. Mean refusal depths for trenches 151 and 170 were 10.4 and $8.5 \mathrm{ft}$, respectively. The postgrouting soil-penetration tests revealed that the stability of the trench after grouting was significantly better than before groutings, and at depths $>8 \mathrm{ft}$, the stability (as measured in terms of soil-penetration) was very near that observed in the native soil formation outside the trench.

Pregrouting tests ranged from 10 to 20 mean blows per foot whereas postgrouting tests ranged from 20 to 40 mean blows per foot. The major differences in results between postgrouting tests and tests conducted in native soil formations outside the trench were found at soil depths of 6,7 , and $8 \mathrm{ft}$. Tests within the trench showed lower stability within this range $(5$ to $8 \mathrm{ft}$ ), probably because of the presence of intermediate-size soil voids (formed during backfilling) that were too small to be penetrated and filled by the conventional cement grout formulation.

Hydraulic conductivity within the trench remained very high $(>0.1 \mathrm{~cm} / \mathrm{s})$ and significantly greater than that outside the trench. Postgrouting air-pressurization tests also revealed a large degree of intervoid linkage within and between the two trenches. Even after grouting, the combined void volume of the two trenches by this test procedure was $80 \mathrm{yd}^{3}$ (compared with $230 \mathrm{yd}^{3}$ for the ungrouted trenches). Only $79 \mathrm{yd}^{3}$ of grout were injected leaving $71 \mathrm{yd}^{3}$ unaccounted for [i.e., total void volume measured $\left(230 \mathrm{yd}^{3}\right)$ minus the sum of the grout injected $\left(79 \mathrm{yd}^{3}\right)$ plus the void volume measured after grouting $\left(80 \mathrm{yd}^{3}\right)$ ]. Thus, it appears that to effectively reduce hydraulic conductivity and to develop stability within the upper level of the trench, it may be necessary to implement additional stabilization steps. One possibility is the injection of a chemical or microfine cement grout into the upper level of the grouted trench which may fill voids too small for the conventional grout.

Grouting of trenches with conventional particulate grouts typically fill only 30 to $60 \%$ of the available void volume, allowing the trenches to remain vulnerable to a certain degree of leaching. On the other hand, chemical grouts typically fill all of the void 
volume but generally tend to be considerably more costly. Certain chemical grouting materials (e.g., acrylamide) are also toxic and present a risk to those who prepare and inject it and are potential contaminants to drinking water supplies. For these reasons, considerable testing is required to demonstrate that the chemical's use will not present unacceptable risks. Recently, microfine-size cements have become readily available. These cements, most often made from finely ground blast-furnace slag, can be used to form slurries capable of attaining permeabilities on the order of $10^{-5}$ to $10^{-9} \mathrm{~cm} / \mathrm{s}$ when injected into fine sands. These highly permeable microfine grout formulations are attractive from the standpoint of being superior to conventional Portland cement grouts in providing hydrologic isolation. However, their costs are approximately ten times that of conventional Portland cements, and in certain instances, their costs are similar to those of chemical grouts.

Recent experience with some microfine cement indicated that low ratios (1:1) of water to cement would have to be used unless special equipment was purchased to suspend suspensions containing high (3:1) water:cement ratios (Table 18). For example, formulations based on high $(3: 1)$ water:cement ratios would require high-energy mixers (those that generate sufficient shear to fully disperse the microfine cement) to avoid significant liquid/solid phase separation. An alternative grout formulation was investigated by using blends of bentonite clay and microfine cement with varying ratios of water. One formulation that was found to be stable and pumpable through a 12-in. column of coarse sand was made using an 8:1:1 ratio of water, bentonite, and microfine cement. Relative to cost, the formulation was much less expensive than chemical grouts or microfine cement grouts formulated on a 1:1 basis. Because of its higher permeability, such a formulation will offer significantly better hydrologic isolation of waste trenches than conventional particulate grouts. Perhaps the best approach is to use a combination of conventional particulate grout to fill the large void spaces, often present at the bottom of the trench, and a microfine grout to fill the intermediate and small void spaces in the upper levels of the trench. This would be economical and technically feasible.

To demonstrate the utility of this approach, it is proposed to inject a clay/microfine cement grout into the upper sections of trenches 151 and 170 . The formulation will be mixed and pumped by the grout module (Fig. 6) into the trenches using the injection wells developed from the postgrout soil-penetration tests (Fig. 19). Slotted pipe (in wells P-3, P-7, P-11, P-15. P-18, and P-20, and P-24) used for the postgrouting air-pressurization tests have been replaced with solid nonslotted pipe. After injection of the clay/microfine cement grout through the remaining slotted injection wells, the solid pipes will be removed and the holes used to determine hydraulic conductivity. Additional soil-penetration tests will also be conducted to examine if the stability in the 5- to 8-ft depths has improved as a consequence of grouting with the clay/microfine cement grout. 


\section{1}

Table 18. Estimated material costs for various grouting scenarios

\begin{tabular}{cccc}
\hline Type & Formulation & \multicolumn{2}{c}{ Estimated costs } \\
of grout & yd $^{3}$ & Trench \\
\hline $\begin{array}{c}\text { conventional } \\
\text { particulate grout }\end{array}$ & $\begin{array}{c}0.7: 1 \\
\text { Water:dry blend }\end{array}$ & $\$ 42$ & $\$ 2,180^{b}$ \\
$\begin{array}{c}\text { Microfine (MF) } \\
\text { cement grout }\end{array}$ & $1: 1$ & & \\
Microfine (MF) & Water:MF cement & $\$ 550$ & $\$ 35,750^{\circ}$ \\
cement grout & $3: 1$ & & \\
$\begin{array}{c}\text { Clay \& MF } \\
\text { cement grout }\end{array}$ & Water:MF Cement & $\$ 260$ & $\$ 16,830^{\circ}$ \\
Polyacrylamide & $\begin{array}{c}8: 2: 1 \\
\text { Water:bentonite:MF cement } \\
\text { Chemical }\end{array}$ & $\$ 160$ & $\$ 10,130^{c}$ \\
\hline \hline
\end{tabular}

${ }^{\circ}$ Grouting formulation used in SWSA-6 trenches 151 and 170 in 1990.

${ }^{b}$ Assumes $65 \mathrm{yd}^{3}$ void space in trench and $60 \%$ of void volume is filled with grout.

'Assumes $65 \mathrm{yd}^{3}$ void space in trench and $100 \%$ of void volume is filled with grout. 


\section{FOLLOW-UP STUDIES \\ GROUTING WITH CLAY-MICROFINE-CEMENT (CMFC) GROUTS}

Grouting trenches 170 and 151 with a particulate-based grout made from Portland Type I cement, fly ash, and bentonite appeared to make a significant improvement in trench stability; thus, the procedure provides assurance against trench subsidence after capping for final closure of the SWSA 6 . However, measurements conducted after grouting indicated that hydraulic conductivity within the trench area remained much greater than hydraulic conductivity of the natural soil formation outside the trench. If the hydraulic conductivity within the trench area is to be significantly decreased, a grout formulation capable of entering and permeating the small void spaces within the trench is necessary. Spalding et al. (1989) demonstrated that polyacrylamide-based chemical grouts were capable of reducing hydraulic conductivities within SWSA 6 burial trenches to values as low as $7.9 \times 10^{-7} \mathrm{~cm} / \mathrm{s}$ (as compared with values of $4.0 \times 10^{-4} \mathrm{~cm} / \mathrm{s}$ for natural soil formations). One alternative to chemical based grouts is a particulate-based grout prepared from very fine grained cement (Zebovitz et al. 1989; Krizek and Helal 1989). These microfine cements have grain-size distributions ( $50 \%$ by weight) of $<5$

Table 19. Properties and composition of microfine cements

\begin{tabular}{ccc}
\hline & MC-100 & MC-500 \\
\hline Properties & Slag & Slag/Portland \\
Cementitious material & 13,000 & 9,000 \\
Fineness $\left(\mathrm{cm}^{2} / \mathrm{g}\right)$ & 3.0 & 3.0 \\
Specific gravity & & \\
$\left(\mathrm{g} / \mathrm{cm}^{3}\right)$ & & \\
\hline Composition $(w t \%)$ & 35.4 & 30.6 \\
$\mathrm{SiO}_{2}$ & 16.0 & 12.4 \\
$\mathrm{Al}_{2} \mathrm{O}_{3}$ & 0.3 & 1.1 \\
$\mathrm{Fe}_{2} \mathrm{O}_{3}$ & 43.3 & 48.4 \\
$\mathrm{CaO}$ & 3.5 & 5.8 \\
$\mathrm{MgO}^{\mathrm{SO}}$ & 0.3 & 0.8 \\
$\mathrm{Total}_{3}$ & 98.8 & 99.1 \\
\hline \hline
\end{tabular}


$\mu \mathrm{m}$ as compared with $<20 \mu \mathrm{m}$ for Type I Portland cements.

The principal manufacturer of these microfine cements is the Onoda Cement Corporation of Japan, and Geochemical Corporation presently markets them in the United States under the names of MC-500 and MC-100 (see Table 19, data taken from Krizek and Helal, 1989). The major difference between the two microfine cements is that the MC-500 contains significant quantities of Portland cement and does not require the use of sodium hydroxide as an activator for the cementitious-hydration process. Limited information is available about their preparation and performance. The manufacturer recommends shear mixing at water-to-cement ratios of $1: 1$ to $3: 1$. At low water-to-cement ratios, the bleeding rate (sedimentation rate following mixing) is small (at 1:1 water-to-cement ratios usually $<10 \%$ of the initial volume), but as the ratio of water-to-cement is increased to $3: 1$, the bleeding rate can be as high as $50 \%$. The amount and rate of bleeding generally decrease with increases in shear mixing time. This may be because of the increased temperature generated on shear mixing which in turn accelerates the hydration process, resulting in a shorter set time and less time available for sedimentation. The $\mathrm{MC}-100$ is less affected by mixing time than MC-500 because the set time of the MC- 100 formulations is more dependent on the amount of sodium hydroxide used as an activator. The intensity of bleeding can be reduced at higher water-to-cement ratios (2:1 and 3:1) by adding bentonite or silica fume.

One of the major advantages of using the higher water-to-cement ratios is the reduced material costs for the microfine cement. For example, material costs for grouting with a 1:1 water-to-cement ratio of microfine cement are nearly that for polyacrylamide chemical grouting (see Table 18). However, with respect to material costs (and reduced bleeding rates), grout formulations using microfine cements in combination with bentonite clays may be an attractive alternative. To investigate their potential use for grouting SWSA 6 burial trenches, treatability studies were initiated for the formulation and testing of CMFC grouts .

\subsection{CMFC FORMULATION STUDIES}

The intent of the initial studies was to form stable suspensions of bentonite clay using sodium hydroxide and sodium hexametaphosphate as dispersants to which quantities of microfine cement (MC-100) were added. Delta gluconolactone (a set retarder and dispersant) was also added in varying amounts $(0.06$ to $0.6 \mathrm{~g} / \mathrm{L})$ to test its influence on fluidity and set time (pumpability over time). The primary performance criterion involved the pumpability of the freshly made grout upward through 12 in. of coarse-textured sand (contained in a 2 in. diam column). Approximately 30 tests were conducted covering ranges in water-to-cement ratios of 1 to 16 , clay-to-cement ratios of 0.5 to 2 , sodium hydroxide concentrations ranging from 2.8 to $28 \mathrm{~g} / \mathrm{L}$, sodium hexametaphosphate ranging from 3 to $37 \mathrm{~g} / \mathrm{L}$, and concentrations of delta gluconolactone ranging from 62 to 621 $\mathrm{mg} / \mathrm{L}$. These tests were carried out by first preparing solutions containing the sodium hydroxide, sodium hexametaphosphate, and delta gluconolactone. Clay suspensions were 
prepared by adding 100 to $200 \mathrm{~g}$ of clay to 700 to $800 \mathrm{~mL}$ of these solutions in a bench-scale laboratory Waring Blender. Clay additions were made in three approximately equal quantities and blended on low speed $(18,500 \mathrm{rpm})$ for $\sim 20 \mathrm{~s}$. To these clay suspensions, $100 \mathrm{~g}$ of $\mathrm{MC}-100$ were then blended to make the grout formulations. On the basis of these preliminary studies, formulations containing $100 \mathrm{~g}$ of bentonite and $100 \mathrm{~g}$ of MC-100 cement in $750 \mathrm{~mL}$ of water containing on the order of $13.2 \mathrm{~g} / \mathrm{L}$ of sodium hydroxide, $200 \mathrm{mg} / \mathrm{L}$ of delta gluconolactone, and $20 \mathrm{~g} / \mathrm{L}$ of hexametaphosphate were the ones most easily pumped to within 1 in. of the top of a 12-in. column of sand. Low concentrations of sodium hydroxide or sodium hexametaphosphate resulted in highly viscous solutions that could not be pumped through the coarse textured sand.

To define more precisely the influence of sodium hydroxide, sodium hexametaphosphate, and delta gluconolactone on the fluidity of CMFC grouts, a $3 \times 3 \times 3$ factorial-designed experiment was conducted. Three levels of sodium hydroxide (4.2, 18.3 , and $41.6 \mathrm{~g} / \mathrm{L})$, sodium hexametaphosphate $(0.28,2.81$, and $28.1 \mathrm{~g} / \mathrm{L})$, and delta gluconolactone $(0,0.17$, and $0.42 \mathrm{~g} / \mathrm{L})$ were used. Grout samples were prepared using $100 \mathrm{~g}$ of bentonite and $100 \mathrm{~g}$ of MC- 100 in $800 \mathrm{~mL}$ aliquots of the appropriate levels of sodium hydroxide, sodium hexametaphosphate, and delta gluconolactone as described above. Fluidity was evaluated by recording the consistency as measured by a Bostwick consistometer (the distance in $\mathrm{cm}$ the grout flowed under its own weight; $24 \mathrm{~cm}$ was the maximum reading) at 30-min intervals over a $2 \mathrm{~h}$ period in which the grout was continuously stirred in a rotary drum mixer at rate of $-30 \mathrm{rpm}$. The $2 \mathrm{~h}$ interval was chosen because this was the estimated time required to pump $400 \mathrm{gal}$ of the CMFC grout into a trench using the grouting module and pump (see Fig. 9). Fluidity of the grout mixtures was strongly influenced by the concentrations of sodium hydroxide and hexametaphosphate. Gluconolactone concentrations appeared to have little influence on fluidity after $2 \mathrm{~h}$ of mixing. Statistical analyses [using the GLM procedure of SAS (1985) and assuming no interactions among the three variables] revealed that increasing levels of sodium hydroxide and hexametaphosphate significantly increased the fluidity of grout (Table 20).

Grout formulations whose fluidity was $>15 \mathrm{~cm}$ after $2 \mathrm{~h}$ of mixing were poured into small plastic cups $(-35 \mathrm{~mL})$ and aged one week in a $+90 \%$ relative humidity chamber to evaluate their setting characteristics (Table 21). Penetrability of the solidified grout forms was determined using a handheld penetrometer. Sodium hexametaphosphate at $28 \mathrm{~g} / \mathrm{L}$ appeared to prevent setting (Table 21). The most promising formulations based on these tests appeared to be those containing $41.6 \mathrm{~g} / \mathrm{L}$ of sodium hydroxide and $2.81 \mathrm{~g} / \mathrm{L}$ of sodium hexametaphosphate (i.e. all formulations showed a fluidity of $>24 \mathrm{~cm}$ and a penetrability of $>4.5 \mathrm{~kg} / \mathrm{cm}^{3}$ ). Additions of gluconolactone (up to $0.42 \mathrm{~g} / \mathrm{L}$ ) did not appear to influence fluidity or penetrability of grout formulated at these concentrations of sodium hydroxide and sodium hexametaphosphate (Table 21). To test the influence of additional loading of bentonite on fluidity, a formulation based on $41.6 \mathrm{~g} / \mathrm{L}$ of sodium hydroxide, $2.81 \mathrm{~g} / \mathrm{L}$ of sodium hexametaphosphate, and $0.17 \mathrm{~g} / \mathrm{L}$ of 
gluconolactone was mixed with $200 \mathrm{~g}$ of bentonite and $100 \mathrm{~g}$ of MC-100 (rather than the $100 \mathrm{~g}$ of bentonite and $100 \mathrm{~g}$ of MC-100). Fluidity of this formulation (using the Bostwick consistometer) after $2 \mathrm{~h}$ mixing remained quite high $(19 \mathrm{~cm})$ which indicated that loading rates of bentonite to $\mathrm{MC}-100$ could be increased to a 2:1 ratio. To test the compressive strength of this formulation, freshly prepared grout was poured into 2-in.-cube molds (see Sect. 2.7.2) and cured for $43 \mathrm{~d}$ in a $+90 \%$ relative humidity chamber. The average compressive strength measurement from three blocks was $66.3 \pm 11.6$ psi.

\subsection{LEACHING STUDIES}

The primary purpose in conducting the leaching studies was to determine if additions of sodium hexametaphosphate to grouting formulations adversely affected the leaching rates of radionuclides, notably strontium, from grout forms. Hexametaphosphate is a condensed cyclic polyphosphate that is known to form soluble complexes with many metals and is widely used in industry as a water softener ("Calgon"). Thus, it was important to evaluate hexametaphosphate's effect on the leaching characteristics of grout formulations. Obviously, injection of a grout containing hexametaphosphate into trenches could result in adverse consequences if hexametaphosphate tended to complex and mobilize radionuclides into soluble forms.

Table 20. Fluidity of grout as influenced by chemicals added ${ }^{l}$

\begin{tabular}{lcc}
\hline Chemical added & $\begin{array}{c}\text { Level } \\
(\mathrm{g} / \mathrm{L})\end{array}$ & $\begin{array}{c}\text { Fluidity } \\
(\mathrm{cm})\end{array}$ \\
\hline Sodium hydroxide & 4.2 & $0.4^{\mathrm{c}}$ \\
& 18.3 & $11.8^{\mathrm{b}}$ \\
& 41.6 & $23.3^{\mathrm{a}}$ \\
\hline Sodium hexametaphosphate & 0.28 & $9.5^{\mathrm{b}}$ \\
& 2.8 & $9.8^{\mathrm{b}}$ \\
& 28.0 & $16.1^{\mathrm{a}}$ \\
\hline Gluconolactone & 0 & $10.6^{\mathrm{a}}$ \\
& 0.17 & $10.7^{\mathrm{a}}$ \\
& 0.42 & $14.1^{\mathrm{a}}$ \\
\hline \hline
\end{tabular}

'Fluidity values for a specific chemical with different superscripts are significantly different at the $5 \%$ level. 
Table 21. Fluidity and penetrability of grouts

\begin{tabular}{|c|c|c|c|c|}
\hline Fluidity & $\begin{array}{c}\text { Sodium } \\
\text { metaphosphate }\end{array}$ & $\begin{array}{c}\text { Sodium } \\
\text { hydroxide }\end{array}$ & Gluconolactone & Penetrability \\
\hline$(\mathrm{cm})$ & & $(g / L)$ & & $\left(\mathrm{kg} / \mathrm{cm}^{2}\right)$ \\
\hline 0.0 & 0.28 & 4.2 & $\mathbf{0}$ & ND $^{\prime}$ \\
\hline 0.0 & 0.28 & 4.2 & 0.17 & ND \\
\hline 0.0 & 0.28 & 4.2 & 0.42 & ND \\
\hline 0.0 & 2.81 & 4.2 & 0 & ND \\
\hline 0.0 & 2.81 & 4.2 & 0.17 & ND \\
\hline 0.0 & 28.09 & 4.2 & 0 & ND \\
\hline 0.0 & 28.09 & 4.2 & 0.17 & ND \\
\hline 0.0 & 0.28 & 18.3 & 0 & ND \\
\hline 0.3 & 2.81 & 18.3 & 0 & ND \\
\hline 1.0 & 28.09 & 4.2 & 0.42 & ND \\
\hline 2.3 & 0.28 & 18.3 & 0.17 & ND \\
\hline 2.5 & 2.81 & 4.2 & 0.42 & ND \\
\hline 4.3 & 2.81 & 18.3 & 0.17 & ND \\
\hline 9.5 & 2.81 & 18.3 & 0.42 & ND \\
\hline 17.8 & 0.28 & 41.6 & 0.17 & 3.5 \\
\hline 18.0 & 0.28 & 18.3 & 0.42 & $<2.5$ \\
\hline 24.0 & 28.09 & 18.3 & 0 & $\mathrm{NS}^{2}$ \\
\hline 24.0 & 28.09 & 18.3 & 0.17 & NS \\
\hline 24.0 & 28.09 & 18.3 & 0.42 & NS \\
\hline 24.0 & 0.28 & 41.6 & 0 & 3.0 \\
\hline 24.0 & 0.28 & 41.6 & 0.42 & 4.5 \\
\hline 24.0 & 2.81 & 41.6 & 0 & $>4.5$ \\
\hline 24.0 & 2.81 & 41.6 & 0.17 & $>4.5$ \\
\hline 24.0 & 2.81 & 41.6 & 0.42 & $>4.5$ \\
\hline 24.0 & 28.09 & 41.6 & 0 & NS \\
\hline 24.0 & 28.09 & 41.6 & 0.17 & NS \\
\hline 24.0 & 28.09 & 41.6 & 0.42 & NS \\
\hline
\end{tabular}

'ND $=$ nol determined

'NS = nousetting 
The leaching characteristics of radio-strontium, -cesium, -cobalt, and tritium from three grout formulations were compared using the ANS-16.1 leaching test (ANSI/ANS 1986). The methods to make the three grout formulations are described in Table 22. Activities of ${ }^{85} \mathrm{Sr},{ }^{57} \mathrm{Co},{ }^{134} \mathrm{Cs}$, and tritium (HTO) were mixed into aliquots of each formulation, which were then poured into $1.5-\mathrm{cm}$-diam and $4.2-\mathrm{cm}$-high cylindrical forms. After setting for $2 \mathrm{~d}$ the solidified grout was removed from the forms and submerged into demineralized distilled water as prescribed in the ANS-16.1 protocol. Two replicates of each formulation were leached. Fresh demineralized water was exchanged at 2, 7, 24, 48, 72, 96, and $120 \mathrm{~h}$ and at 18, 46, and $91 \mathrm{~d}$. Activities of the gamma emitting radionuclides were determined in the leach solution (and compared with activities added to the solidified forms in the same counting geometry) using a high-resolution, solid-state, coaxial, lithium-drifted, germanium [Ge(Li)] detector coupled to a ND6700 multichannel analyzer with 4096 channels. Tritium (HTO) levels in the leach solutions were determined by liquid scintillation counting after correcting for counting efficiencies of selected aliquots whose tritium levels were determined by EPA Method 906.0. Replicate leachates were not analyzed for tritium (i.e., single replicates), and only those leachates collected the first $120 \mathrm{~h}$ were analyzed.

The leachability index (L) defined by the ANS-16.1 procedure is the negative log of the effective diffusivity (D) of a nuclide from a test material; i.e.,

$$
L=\log \left(\frac{\beta}{D}\right)
$$

where $\beta$ is a defined constant of $1.0 \mathrm{~cm}^{2} / \mathrm{s}$, and $D$ is expressed in units of $\mathrm{cm}^{2} / \mathrm{s}$, making $\mathrm{L}$ a dimensionless parameter. The effective diffusivity (D) is determined experimentally over ten discrete time intervals ranging from 2 to $1032 \mathrm{~h}$ over $90 \mathrm{~d}$ (for more information about the test, see ANSII/ANS-16.1 1986). The full-scale test inyolves expressing the leaching index as an average of the required ten leaching intervals (up to $90 \mathrm{~d}$ ). These values were determined for ${ }^{57} \mathrm{Co},{ }^{134} \mathrm{Cs}$, and ${ }^{85} \mathrm{Sr}$. However, for tritium leaching an abbreviated test (up to $120 \mathrm{~h}$, using the average of 7 rather than 10 leaching intervals) was conducted.

Leachability indexes for ${ }^{57} \mathrm{Co},{ }^{134} \mathrm{Cs},{ }^{85} \mathrm{Sr}$, and HTO from the three grout formulations are presented in Table 23. The cobalt radioisotope was very slowly leached from all three formulations (leachability indexes of $\sim 12$ ). The major differences in the leaching characteristics of the three formulations were the much lower leaching indexes (i.e., higher leaching rates) for ${ }^{134} \mathrm{Cs}$ and ${ }^{85} \mathrm{Sr}$ with the Portland cement-based grout as compared with those of the microfine- or CMFC-based grout. The lower leaching indexes for these radionuclides imply that the leaching of these radionuclides is on the order of $\sim 1000$ times faster from Portland cement-based grout than those made from microfine cement. The "abbreviated" leachability index (taken over the first $120 \mathrm{~h}, \mathrm{n}=7$ ) 
Table 22. Description of grouting formulations

\begin{tabular}{ll}
\hline \multicolumn{1}{c}{ Formulation } & \multicolumn{1}{c}{ Method of Formulation } \\
\hline CMFC & $\begin{array}{l}200 \mathrm{~g} \text { of bentonite and } 100 \mathrm{~g} \text { of } \mathrm{MC}-100 \mathrm{in} 800 \mathrm{~mL} \text { mixed into a } \\
\text { solution containing } 41.6 \mathrm{~g} / \mathrm{L} \text { of sodium hydroxide, } 2.81 \mathrm{~g} / \mathrm{L} \text { of sodium } \\
\text { hexametaphosphate, and } 0.17 \mathrm{~g} / \mathrm{L} \text { of gluconolactone with a Waring } \\
\text { Blender }\end{array}$ \\
& $\begin{array}{l}673 \mathrm{~g} \text { of MC- } 100 \mathrm{mixed} \text { with } 700 \mathrm{~mL} \text { of water, } 50 \mathrm{~mL} \text { of } 50 \% \text { sodium } \\
\text { hydroxide, and } 5.5 \mathrm{~mL} \text { of Ca-600 (a commercial dispersant marketed } \\
\text { by Geochemical Corporation, Ridgewood, New Jersey) with a Waring } \\
\text { Blender }\end{array}$ \\
$\begin{array}{l}\text { Conventional grout formula } \\
\text { (used in trenches 151 and } \\
170)\end{array}$ & $\begin{array}{l}585 \mathrm{~g} \text { of Portland Type I cement, } 825 \mathrm{~g} \text { of ASTM Class F fly ash, and } \\
82 \mathrm{~g} \text { of bentonite mixed with } 1000 \mathrm{~mL} \text { of water in a table top rotary } \\
\text { mixer }\end{array}$ \\
\hline \hline
\end{tabular}

for tritium did not appear to vary so much between the different grout formulations. However, closer evaluation of the data reveals that the leaching index (using Eq. 1 of ANS 1986) for tritium was highly dependent on time (Fig. 24). For example, the leaching index for HTO from the microfine MC-100-based grout ranged from $<6$ at 2 $\mathrm{h}$ to near 11 after $100 \mathrm{~h}$ of leaching. Leaching of HTO from the Portland cement-based grout showed a similar trend. In contrast, the leaching of HTO from the CMFC-based grout was very uniform over time. In terms of quantity of HTO leached from each of the grouts, $-100 \%$ of the HTO had leached from both Portland-and microfine MC-100-based grouts after $\sim 30 \mathrm{~h}$, whereas $>30 \%$ of the HTO remained with the CMFC-based grout after $120 \mathrm{~h}$ of leaching (see Fig. 25). These data clearly show that the CMFC-based grout would be clearly superior to those made solely from Portland or microfine cements in reducing the leaching of any of these radionuclides from the grouted form.

The cementitious setting action of microfine cements is activated by adding caustic to the formulation. In contrast, Portland-based cements contain sufficient quantities of exchangeable calcium to activate the cementitious reaction; thus, additions of caustic are not needed. Of some environmental concern is the resulting caustic effect of

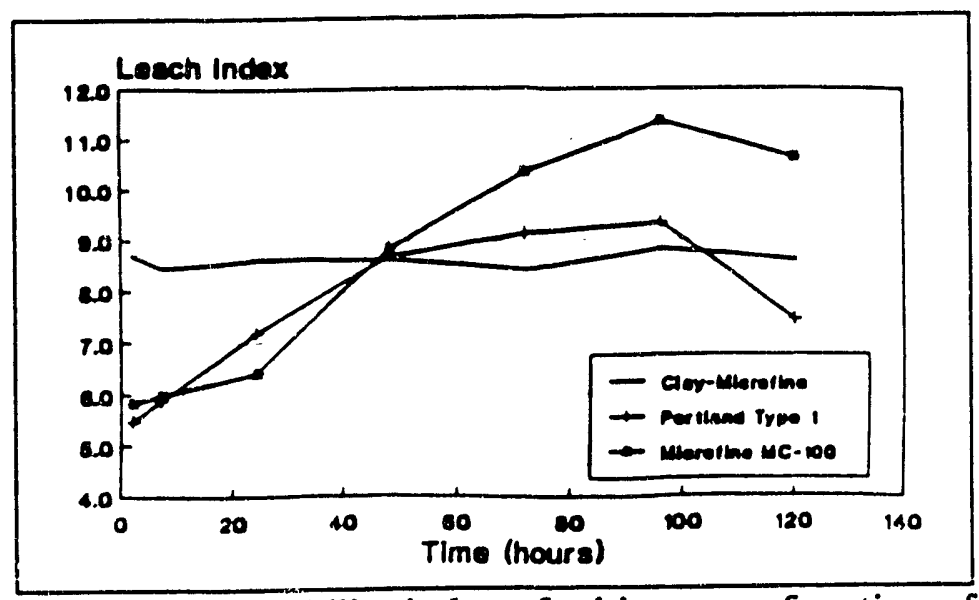

Fig. 24. Leachability index of tritium as a function of time. 
Table 23. Leachability indexes measured for three grout formulations

\begin{tabular}{rcccc}
\hline Formulation & ${ }^{57} \mathrm{Co}$ & ${ }^{134} \mathrm{Cs}$ & ${ }^{85} \mathrm{Sr}$ & HTO \\
\hline Portland (Type 1) & & & & \\
1 & $13.1 \pm 0.5$ & $6.3 \pm 0.5$ & $7.1 \pm 0.4$ & $5.33 \pm 0.05$ \\
2 & $12.0 \pm 0.7$ & $6.3 \pm 0.5$ & $7.0 \pm 0.4$ & \\
Microfine MC-100 & & & & \\
1 & $12.1 \pm 1.1$ & $9.1 \pm 0.8$ & $10.3 \pm 0.6$ & $5.69 \pm 0.05$ \\
2 & $11.3 \pm 0.7$ & $9.1 \pm 0.7$ & $10.3 \pm 0.7$ & \\
Clay-microfine & & & & \\
1 & $12.8 \pm 1.1$ & $9.7 \pm 0.7$ & $10.5 \pm 0.6$ & $8.9 \pm 0.2$ \\
2 & $12.5 \pm 1.1$ & $9.7 \pm 0.7$ & $10.5 \pm 0.7$ & \\
& & & & \\
\hline
\end{tabular}

from the use of microfine cements that depend on caustic additions to initiate their cementitious reaction. For this reason, the $\mathrm{pH}$ of the leachates generated during the ANS-16.1 test was monitored. Generally speaking, the $\mathrm{pH}$ values measured on leachate generated from the Portland cement-based grouts were higher throughout the $90 \mathrm{~d}$ leach period than those leachates generated from the microfine cement-based grouts (see Fig. 26). During the early stages of leaching $(<20 \mathrm{~d})$, the $\mathrm{pH}$ of leachates from the CMFC grout was generally from 0.5 to $1.0 \mathrm{pH}$ unit below that of the grout prepared from the Portland Type I cement. After $90 \mathrm{~d}$, the $\mathrm{pH}$ of both leachates ranged between 10.5 and 11.0 (see Fig. 26). Thus, these data indicate that the use of microfine cements that require caustic to activate then, probably do not elevate the $\mathrm{pH}$ of the surrounding media any more than grouts made from Portland Type I cement.

\subsection{TRENCH GROUTING WITH A CMFC BASED-GROUT}

Wells formed from postgrout soil-penetration tests were used to inject the CMFC-based grout into trenches 170 and 151 (Fig. 19). Injection wells were similar to those in the Phase $\bar{I}$ studies (those where a Portland Type I cement-based grout was injected in trenches 151 and 170 in the summer of 1990), with two exceptions. One, the 
PVC piping (Schedule 80, 1.25-in. ID diam.) used for injection of CMFC was constructed of 0.02 -in.-wide slots rather than the 0.1-in.-wide slotted pipe used in Phase I. Laboratory and field tests demonstrated that CMFC could easily be pumped through this type of pipe. For example, field tests revealed that the grout could be pumped at rates in excess of $20 \mathrm{gal} / \mathrm{min}$ with pressure drops $<10$ psi at the grouting

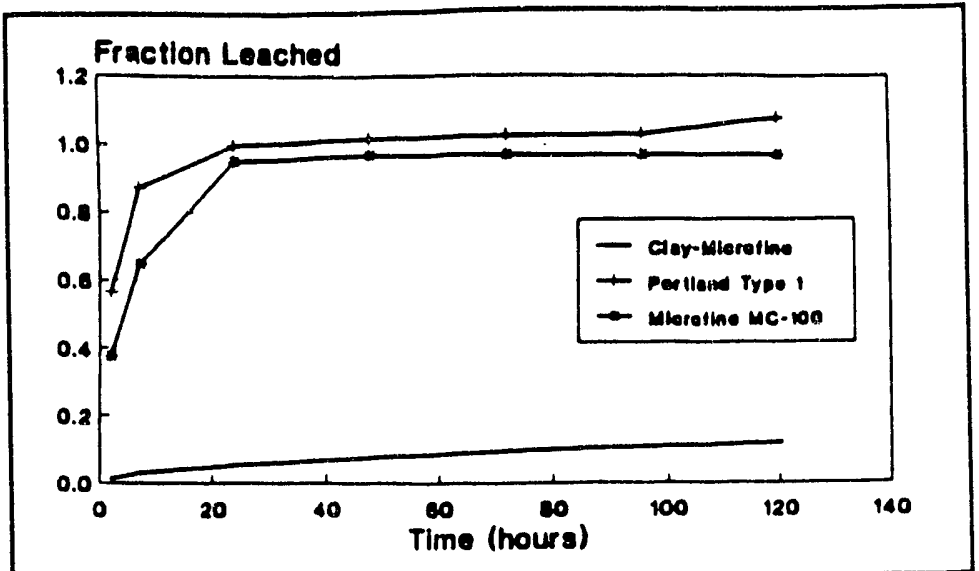

Fig. 25. Fraction of tritium leached from selected grout formulations as a function of time. unit. The second difference was in the manner in which the pipe/soil interface at the surface was treated. In Phase I studies, to ensure that injected grout did not return to the surface along the pipe/soil interphase, a 1-ft section of 2 -in.-diam pipe was placed around the 1.25-in.-diam injection pipe and driven into the ground to $\sim 3$ in. below the soil surface. On being driven into the ground, soil was forced between the two pipes forming a tight seal at the pipe/soil interphase. A cement-based grout collar was then molded around the surface of the pipe/soil interphase (see Fig. 4). In this study, a 1-ft section of 2-in.-diam pipe was not placed around the injection pipe and driven into the ground as was done in the Phase I study, the rationale being that such a procedure was not needed because of the high fluidity of CMFC. However, the same type of a

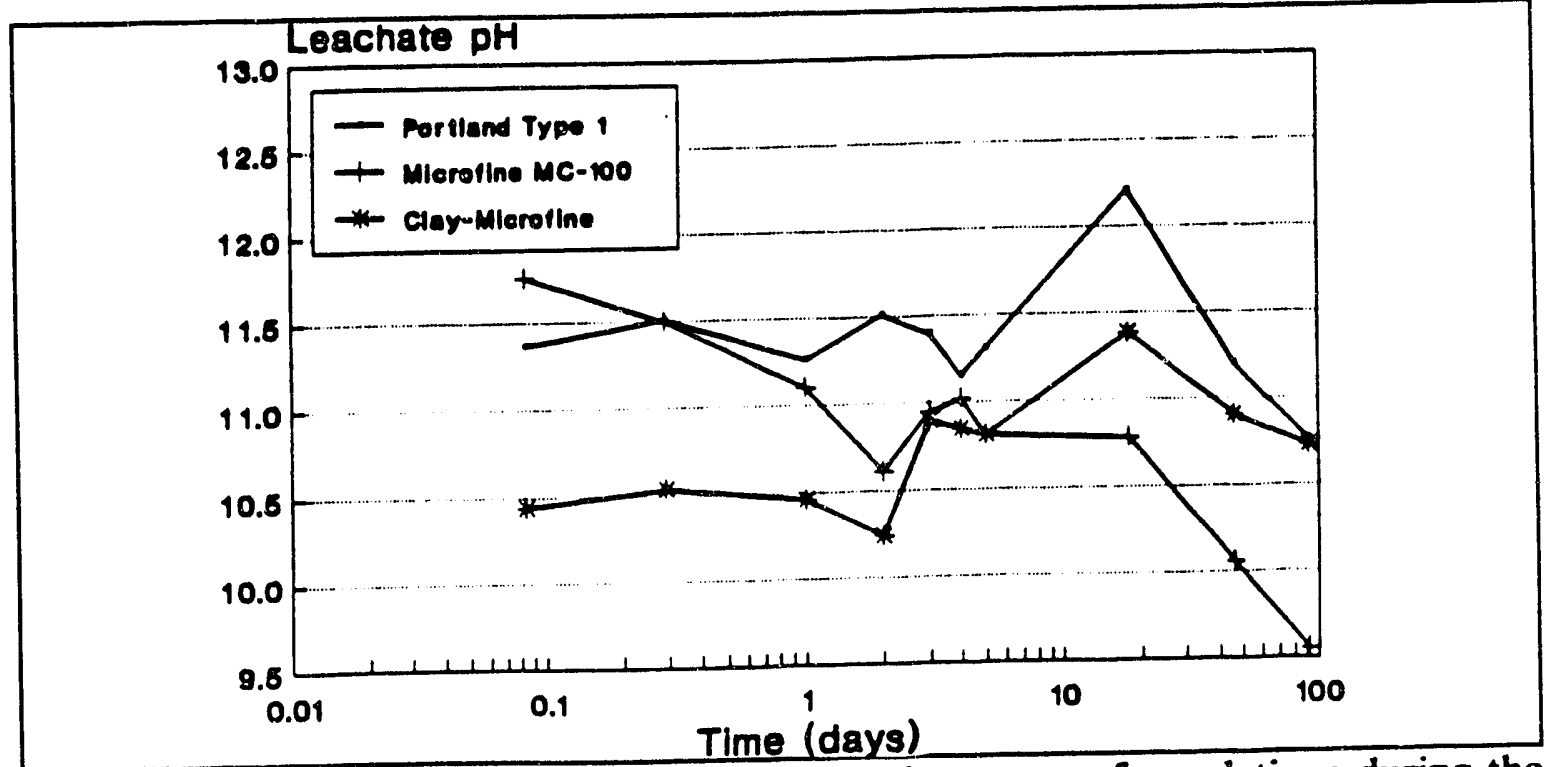

Fig. 26. The $\mathrm{pH}$ of leachate generated from three grout formulations during the ANS-16.1 leaching test 
cement-based grout collar was installed around each of the wells.

\subsubsection{Preparation of CMFC at the Field Site}

In the laboratory, bentonite clay suspensions ( $25 \%$ by weight) were made using a high shear laboratory blender. For field studies, a cyclonic-action-type blender was used (Sidewinder Mixer ${ }^{\mathrm{Tx}}$, Model SW-100 manufactured by Swaco Geolograph, Oklahoma City, Oklahoma). This type of blender is routinely used to prepare drilling muds in the oil drilling industry. To do this, $150 \mathrm{lb}$ of flaked grade caustic soda, $10 \mathrm{lb}$ of sodium hexametaphosphate (Calgon, powdered grade), and $0.6 \mathrm{lb}$ of delta gluconolatone were blended with $400 \mathrm{gal}$ of water in one of the 500 -gal tanks of the grouting unit. This solution was circulated through the cyclonic blender, while $800 \mathrm{lb}$ of cement-grade bentonite clay (Big Horn ${ }^{\text {m }}$ Chemical Grade, $80 \%$ passing a 200 mesh screen purchased from Wyo-Ben, Inc., Billings, Montana) were added in 50-1b increments. MC-100 was then blended (444 lb in ten $44.4 \mathrm{lb}$ increments) with the clay suspension using the "lighting type" mixers mounted on the 500-gal tanks of the grouting unit. Preparation of the clay suspension and addition of the microfine cement were carried out by personnel wearing full face-masked respirators and chemical splash jackets (Fig. 27).

\subsubsection{Trench Injection of CMFC}

CMFC was injected into the trenches by pumping the grout from the $500-\mathrm{gal}$ holding tanks using the grouting unit pumps at operating pressures $<50$ psi. A description of these injections is presented in Table 24. Approximately $4 \mathrm{yd}^{3}$ of grout was injected into trenches 170 and 151 . The total quantity injected was severely limited because of continued leaking of grout to the soil surface at the pipe/soil interface of the injection wells. Except for well P-17, grout broke through at the base of all wells after pumping 3 to $4 \mathrm{~min}$. Pumping rates (10 to $20 \mathrm{gal} / \mathrm{min}$ at grouting pressures $<25 \mathrm{psi}$ ) exceeded the hydraulic capacity of soil, thus causing grout to be forced upward along the injection pipe and breaking through to the soil surface around the cement-based collar installed to prevent the bleeding of grout back to the soil surface. In the Phase I studies, to ensure that injected grout did not return to the surface along the pipe/soil interphase, a 1 -ft section of 2-in.-diam pipe was placed around the 1.25-in.-diam injection pipe and driven into the ground to $\sim 3$ in. below the soil surface. The same procedure should have been used for these studies even though the fluidity of CMFC approached that of water. Estimates of hydraulic conductivity within the trenches after Phase I grouting were in excess of $0.1 \mathrm{~cm} / \mathrm{s}$ [i.e., $6 \mathrm{~L}$ of water could be poured into the wells formed from soil-penetration tests over a 23-s interval without overflowing the well casing (a flow rate of $\sim 4 \mathrm{gal} / \mathrm{min})]$. However, grout injection rates were $\sim 10$ to $20 \mathrm{gal} / \mathrm{min}$ and resulted in considerable backflow of grout upward along the injection wells. 


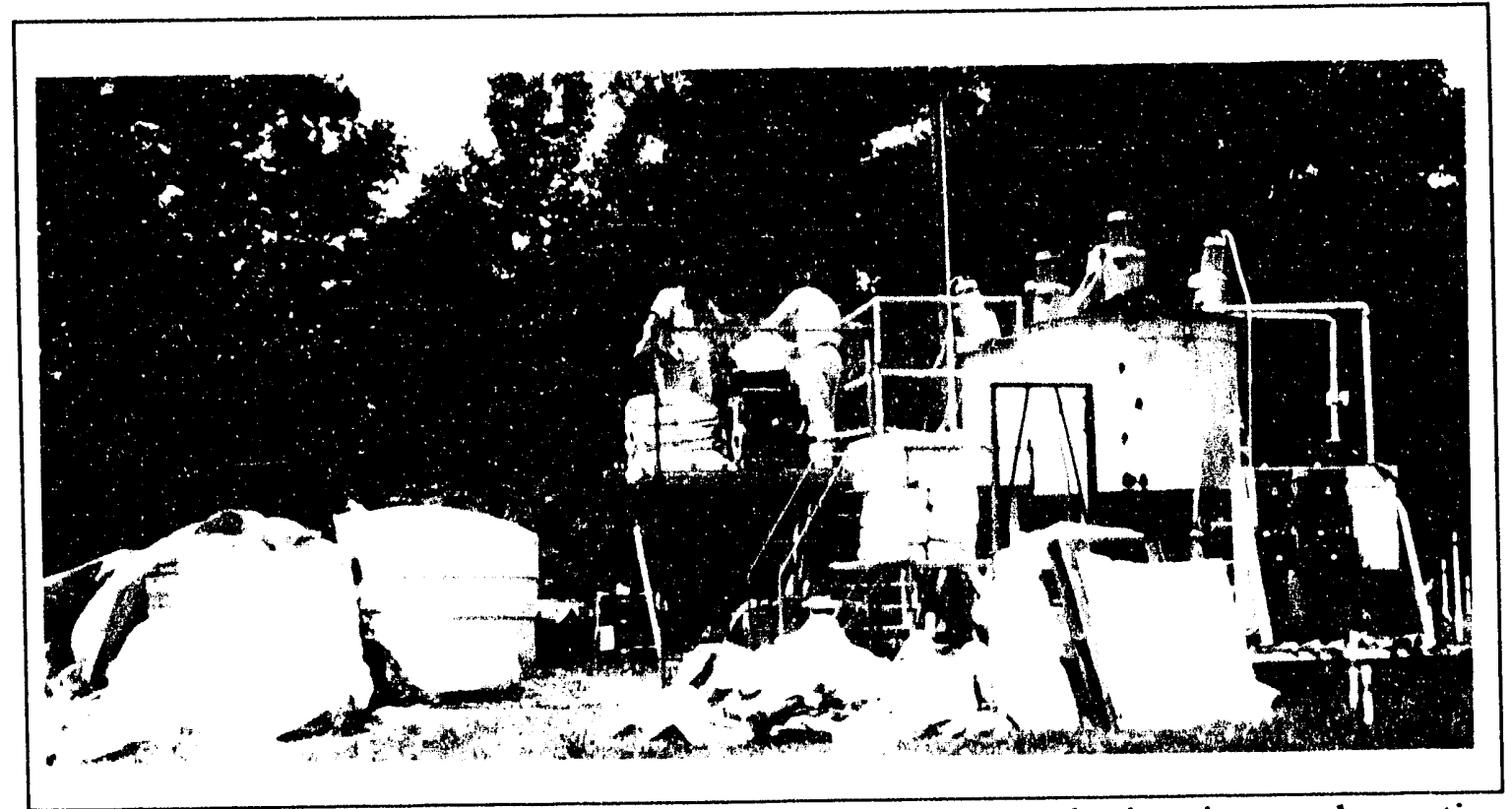

Fig. 27. Preparation of the grout formulation using a cyclonic mixer and grouting unit at the field site (ORNL 7096-91).

Approximately $8.1 \mathrm{yd}^{3}$ of CMFC was pumped into well 151-SW (see Table 24). This was a well installed outside the trench 151 area to monitor groundwater. However, because of the quantity of grout that could be pumped into the well at such high flow rates $\left(2.3 \mathrm{yd}^{3}\right.$ over a 20 -min interval, $\left.>20 \mathrm{gal} / \mathrm{min}\right)$ it was apparent that the well was either in or directly linked to the adjoining trench (trench 148).

During the last week of July and first week of August, the injection wells in trenches 170 and 151 were modified (using the procedure implemented in the Phase I studies) to ensure that any additional injections of grout would not return to the soil surface along the pipe/soil interface. This involved removing the previously installed cement-based grout collar from around the injection wells and the installation of a $1-\mathrm{ft}$ section of 2 -in.-diam pipe around the 1.25-in.-diam injection pipe. After driving this section into the ground to -3 in. below the soil surface, a new cement-based grout collar was then molded around the surface of the pipe/soil interphase. In addition, four injection wells (using PVC 0.1 -in.-wide slotted pipe) were installed in trench 148 (Fig. 28).

Grouting of trenches 151 and 170 was resumed on August 8, 1991 (see Table 24). The total quantity of grout pumped into these two trenches on that date was $8.3 \mathrm{yd}^{3}$. This quantity added to that injected July 22 and $23\left(4 \mathrm{yd}^{3}\right)$ totals to slightly more than $12 \mathrm{yd}^{3}$. Modification of the pipe/soil interphase of the injection wells eliminated the leaking of grout to the soil surface at the pipe/soil interphase. Breakthrough of grout to the soil surface was usually several feet away from the injection well. In a number of cases, grout surfaced out at the top of adjacent injection wells (see Table 24), indicating 


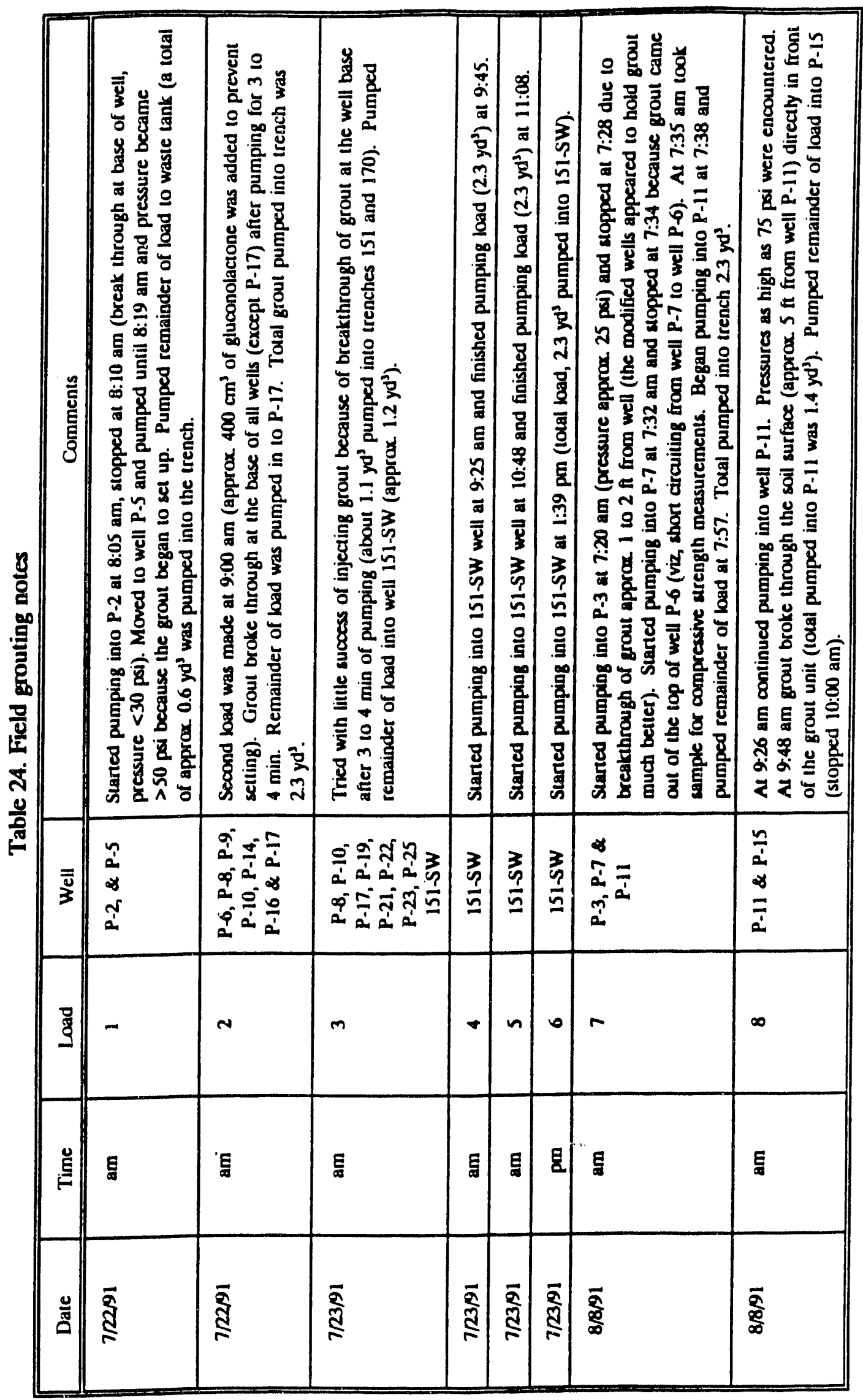




\begin{tabular}{|c|c|c|c|c|c|c|c|c|c|c|c|}
\hline 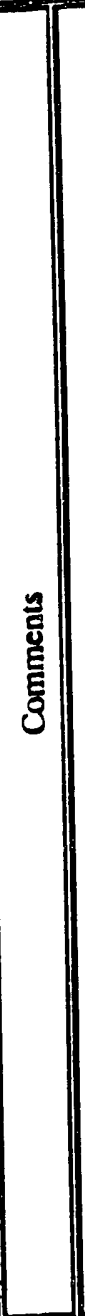 & 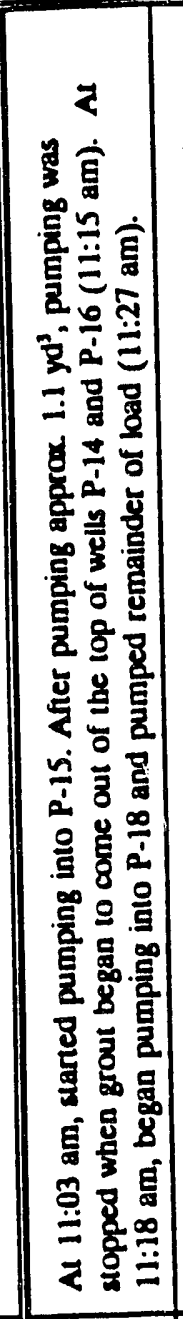 & 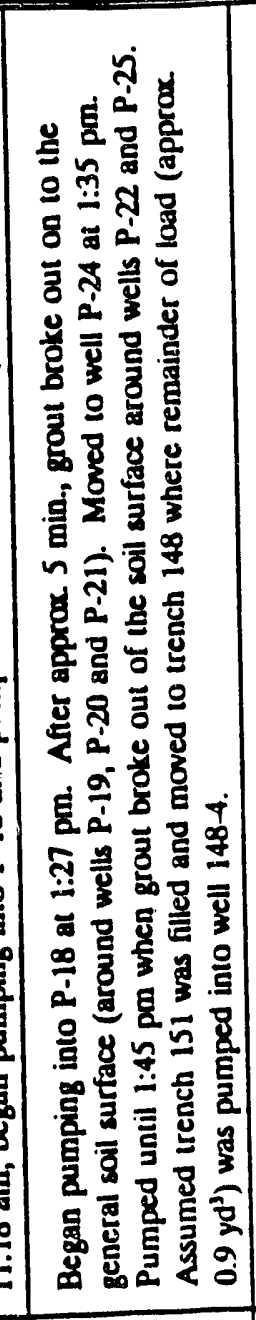 & 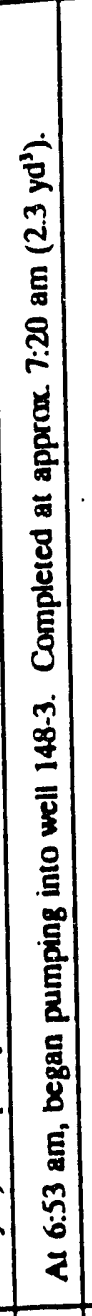 & 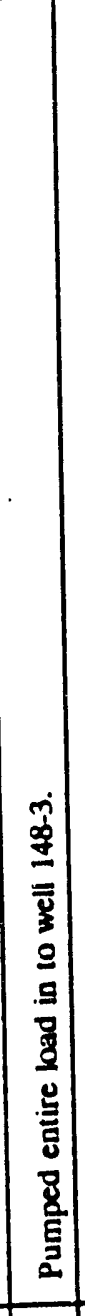 & 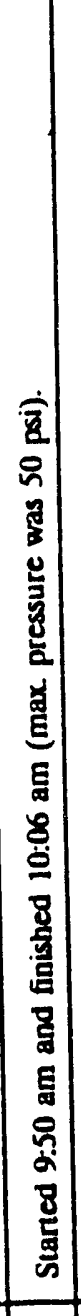 & 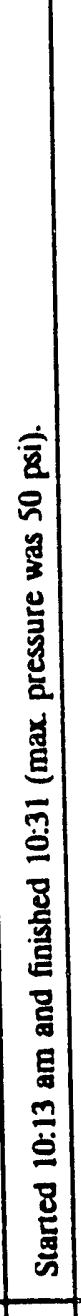 & 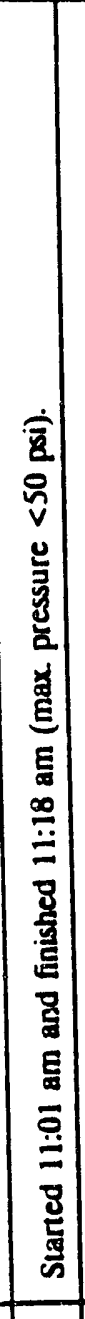 & 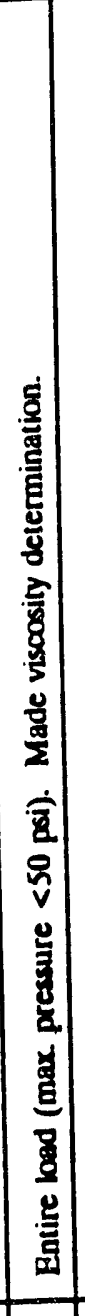 & 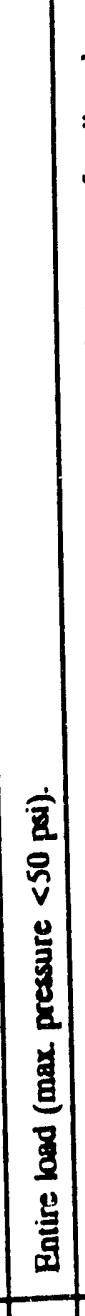 & 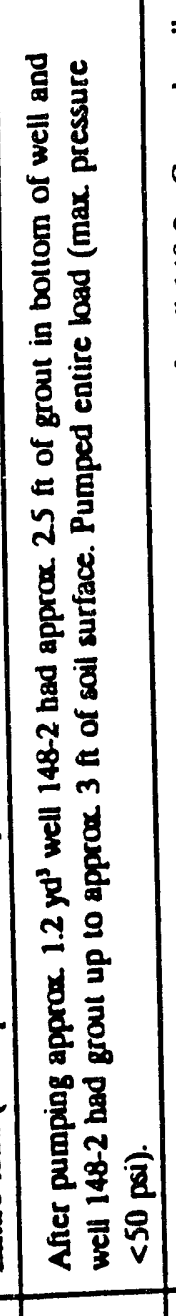 & 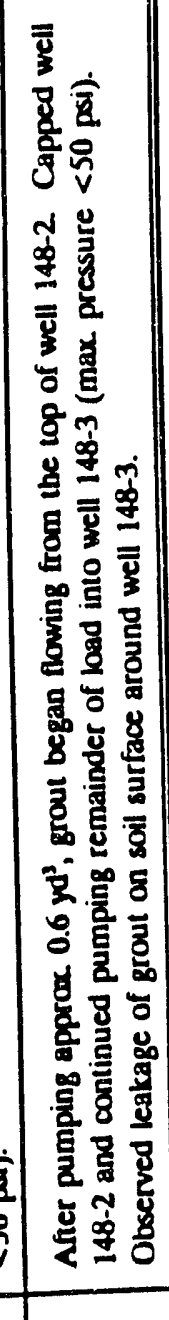 \\
\hline$\overline{\overline{0}}$ & $\begin{array}{l}\frac{\infty}{2} \\
a \\
\simeq \\
\frac{a}{2}\end{array}$ & 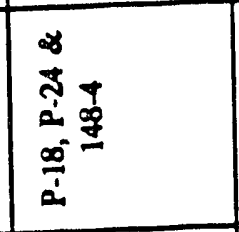 & 总 & 离 & 离 & 宣 & 旁 & 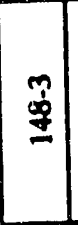 & 全 & $\hat{q}$ & 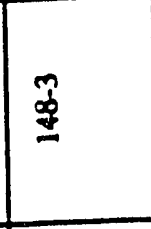 \\
\hline 疋 & a & 요 & $=$ & $\simeq$ & $\underline{m}$ & \pm & $\simeq$ & $\underline{0}$ & $=$ & $\stackrel{\infty}{\varrho}$ & 9 \\
\hline$\stackrel{\mathscr{E}}{\underline{E}}$ & 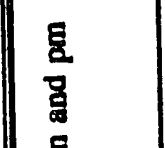 & 空 & $\underline{E}$ & $\underline{E}$ & $\underline{\varepsilon}$ & E्⿱一𫝀口 & $\underline{\Xi}$ & 是 & हू & 焉 & E् \\
\hline$\stackrel{u}{\mathrm{~g}}$ & 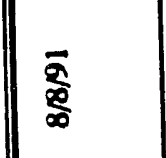 & $\underset{\infty}{\bar{\infty}}$ & $\frac{\overline{2}}{\stackrel{m}{\infty}}$ & $\stackrel{\overline{2}}{\stackrel{\bar{\infty}}{\infty}}$ & $\frac{\bar{\Sigma}}{\sum_{\infty}}$ & 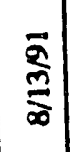 & $\underset{\bar{\infty}}{\overline{\bar{\alpha}}}$ & $\frac{\bar{\alpha}}{\bar{\alpha}}$ & $\frac{\bar{\alpha}}{\sigma}$ & $\frac{\partial}{\hat{a}}$ & $\frac{\bar{a}}{\hat{\alpha}}$ \\
\hline
\end{tabular}




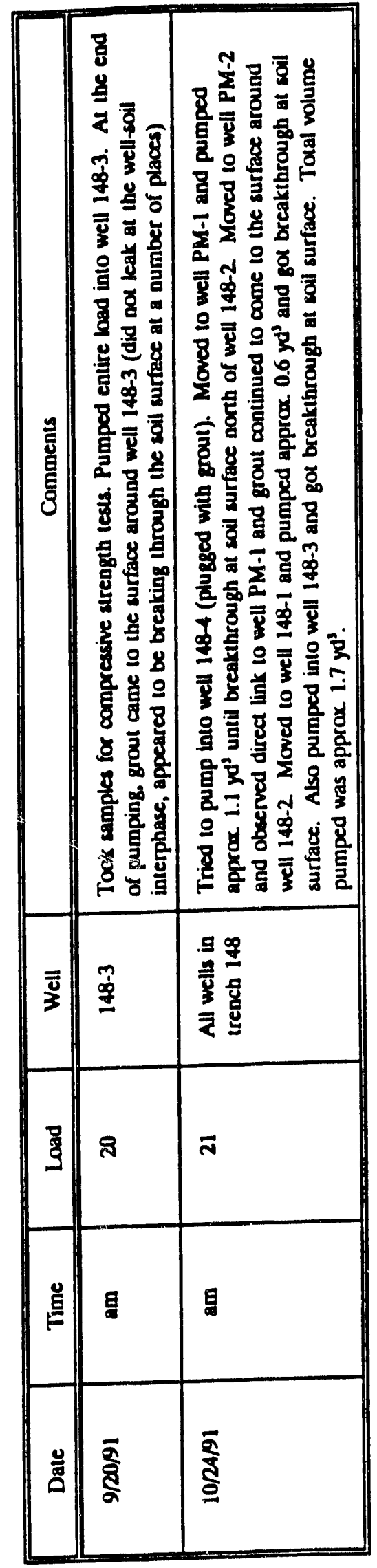


considerable subsurface movement of grout within the trench.

Trench 148 was prepared for grouting with CMFC. This action was taken because it didn't appear that large quantities of CMFC could be injected into a trench previously grouted with a Portland Type I-based cement grout (trenches 151 and 170). Grouting trench 148 with CMFC would provide an additional data base in our trench grouting studies. For example, grouting data would be available for (1) trenches grouted with a conventional Portland Type I-based grout, (2) trenches grouted with CMFC after grouting with the conventional Portland Type I-based grout, and (3) a trench grouted solely with CMFC. Soil-penetration and hydraulic conductivity tests on these trenches before and after grouting would determine the effectiveness of the various grouting scenarios.

Trench 148 was grouted with CMFC at intermittent dates in August, September, and October of 1991 (Table 24). Ideally it may have been preferred to grout a trench in one single continuous operation (at least on a day-to-day basis); however, equipment failures and difficulties in obtaining Plant \& Equipment personnel to operate the grouting unit precludeci such an operation. In retrospect, grouting under these conditions demonstrated the utility of not requiring a single continuous operation. For example, grouting on a day-to-day basis allowed measurement of grout levels in injection wells, and because slotted pipe was used to inject grout, the same well could be used to inject

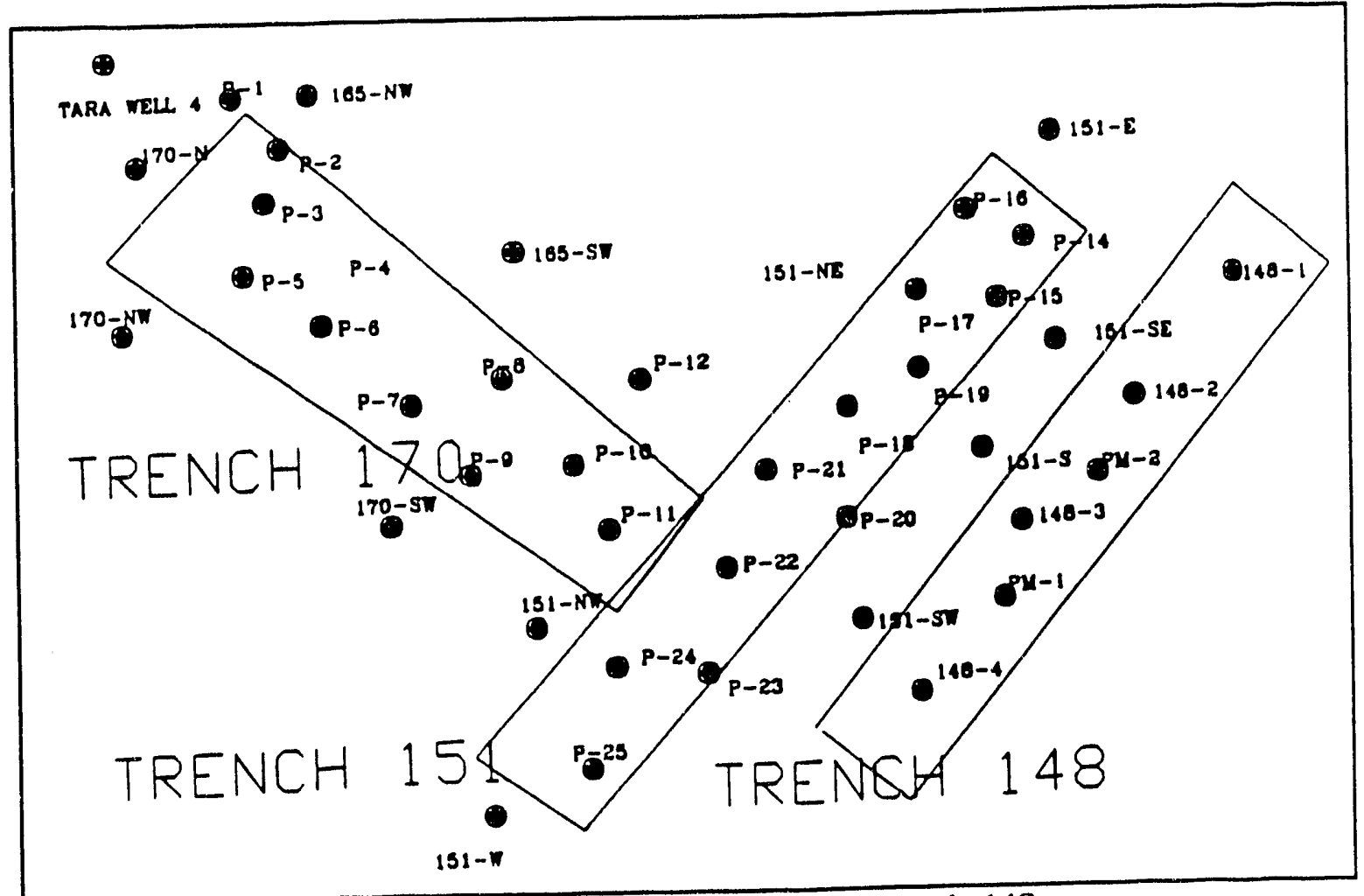

Fig. 28. Location of wells used to inject grout into trench 148. 
grout the following day or several days later. A total of $25.7 \mathrm{yd}^{3}$ of grout was injected into trench 148 during August through October (see Table 24). This quantity added to the $8.1 \mathrm{yd}^{3}$ of grout injected into well 151-SW (assumed to be linked to trench 148) gives a total of $33.8 \mathrm{yd}^{3}$ injected into trench 148 . The total void volume of trench 148 was not determined; thus, any calculation of the efficiency in filling its void volume can not be made. For comparison, trenches 151 and 170 received $91 \mathrm{yd}^{3}$ of grout $\left(79 \mathrm{yd}^{3}\right.$ of conventional Portland Type I-based grout and $12 \mathrm{yd}^{3}$ of CMFC).

\subsubsection{Field Testing of CMFC Grouted Trenches}

Soil-penetration and hydraulic conductivity tests were conducted within trenches 151,170 , and 148 prior to and after grouting with CMFC. Compressive strength and viscosity measurements of field grout samples were also determined. For example, the compressive strengths of three samples taken during the August 8, 1991, field injections were $34.4 \pm 1.5 \mathrm{psi}$ (aged $60 \mathrm{~d}$ in $+90 \%$ relative humidity chamber), considerably lower than the 66.3 psi measured on the laboratory-generated samples (see sect. 5.1). Field viscosity measurements for CMFC were made by comparing flow rates through a specially designed funnel with flow rates of water and a $72 \%$ glycerol solution. Estimates of CMFC viscosity determined in this manner were 5 to $6 \mathrm{cP}$.

Soil-penetration tests from the Phase I studies showed a marked improvement in trench stability following grouting with the conventional Portland Type I-based cement grout (see Fig. 13 of Phase I studies). Soil-penetration tests in trenches 151 and 170 (locations illustrated in Fig. 29) after grouting with CMFC gave the indication that the stability within the trenches was less than that after grouting with Portland Type I based grout (see Fig. 30); viz, the average number of blows per foot for penetration tests after grouting with CMFC was considerably less. However, statistical analyses (using Proc GLM with Duncan's multiple-range test, SAS 1985) revealed significant differences $(\mathrm{P}<0.05)$ only at the $1-$ and 7 - $\mathrm{ft}$ depths (see Appendix B). At the $7 \mathrm{ft}$ depth, the average number of blows per foot after grouting with CMFC was significantly less than the average number of blows per foot in soil outside the trench, but it was not significantly different from the average number of blows per foot following grouting with the Portland Type I-based grout, indicating that the grouting with CMFC did not significantly affect the stability of the two trenches.

Soil-penetration tests in trench 148 indicated that grouting with CMFC did not significantly affect trench stability (see Fig. 30). Statistical analyses of the soil penetration data revealed no significant differences in the average number of blows per foot before and after grouting; however, at soil depths $>5 \mathrm{ft}$ they were significantly lower than the average number of blows per foot in soil outside the trench (see Appendix C). These data also indicate that grouting with CMFC did not significantly affect the stability of trenches.

Hydraulic conductivity measurements following grouting with CMFC were 


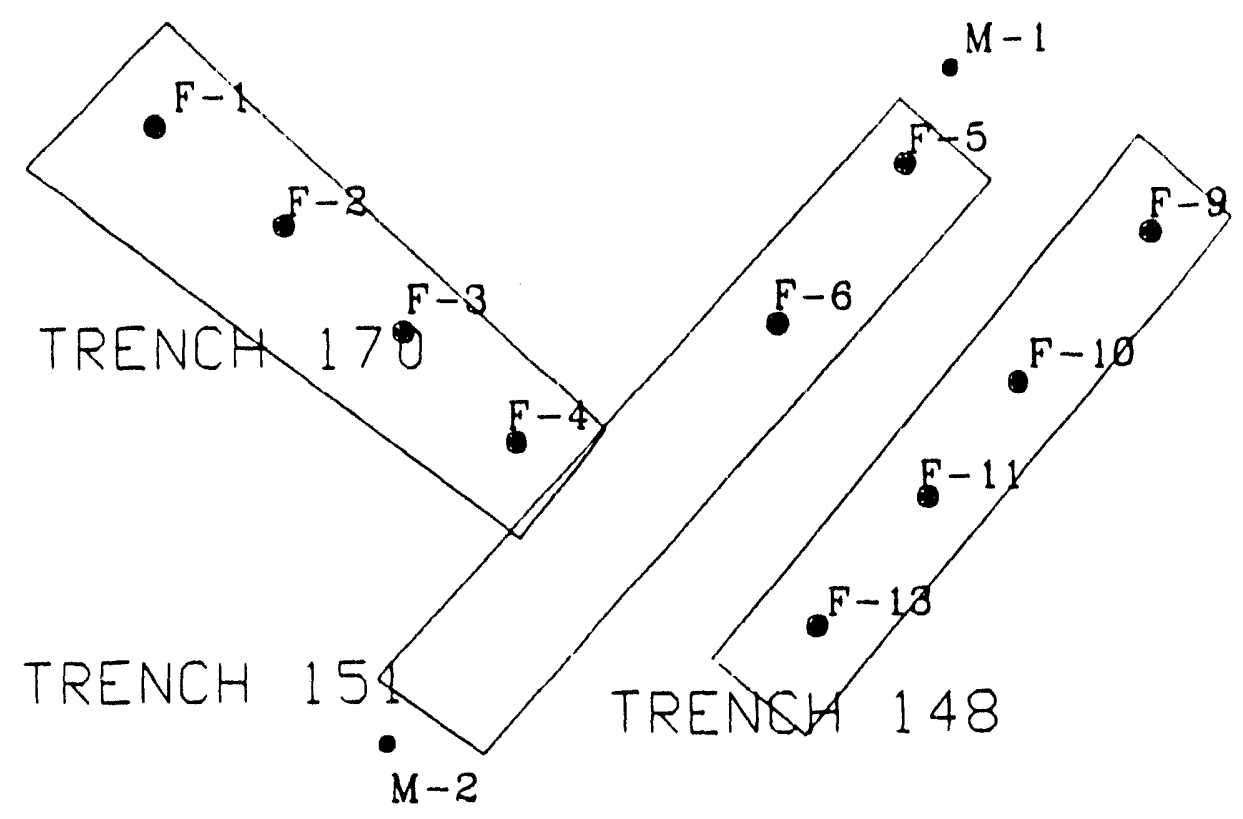

Fig. 29. Locations within trenches 148,151 , and 170 where hydraulic conductivity measurements were taken.

conducted in wells formed from the soil penetration tests. In this case, 5- $\mathrm{ft}$ sections of 2-in.-diam PVC pipe were driven into the well to form an infiltration barrier for the top $5 \mathrm{ft}$ of soil. Hydraulic conductivities of the grouted trench area surrounding each well were determined using a constant head pump-in test (Spalding et al. 1985).

Hydraulic conductivities were calculated using the following formula

$$
K=\frac{q \ln \left[\frac{m L}{D}+\left(1+\left(\frac{m L}{D}\right)^{2}\right)^{1 / 2}\right]}{2 \pi L H_{z}}
$$

where

$\mathbf{K}=$ hydraulic conductivity in $\mathrm{cm} / \mathrm{sec}$,

$q=$ rate of water intake in $\mathrm{cm}^{3} / \mathrm{sec}$,

$\mathrm{L}=$ length of intake section in $\mathrm{cm}$,

$\mathrm{H}_{2}=$ constant piezometric head in $\mathrm{cm}$ of water which equals the height of the water in the casing above the water table,

$\mathrm{D}=$ diameter of well casing in $\mathrm{cm}$, and

$\mathrm{m}=$ transformation ratio, assumed to be 1 . 
Six measurements were made in trenches 151 and 170 , and four were made in trench 148 (see Fig. 29 and Table 25). The average hydraulic conductivity in trenches 151 and 171 after grouting was $1.2 \times 10^{-3} \mathrm{~cm} / \mathrm{s}$. After grouting trench 148 with CMFC, the average hydraulic conductivity was $1.7 \times 10^{-3} \mathrm{~cm} / \mathrm{s}$. Two measurements of hydraulic conductivity in soil outside

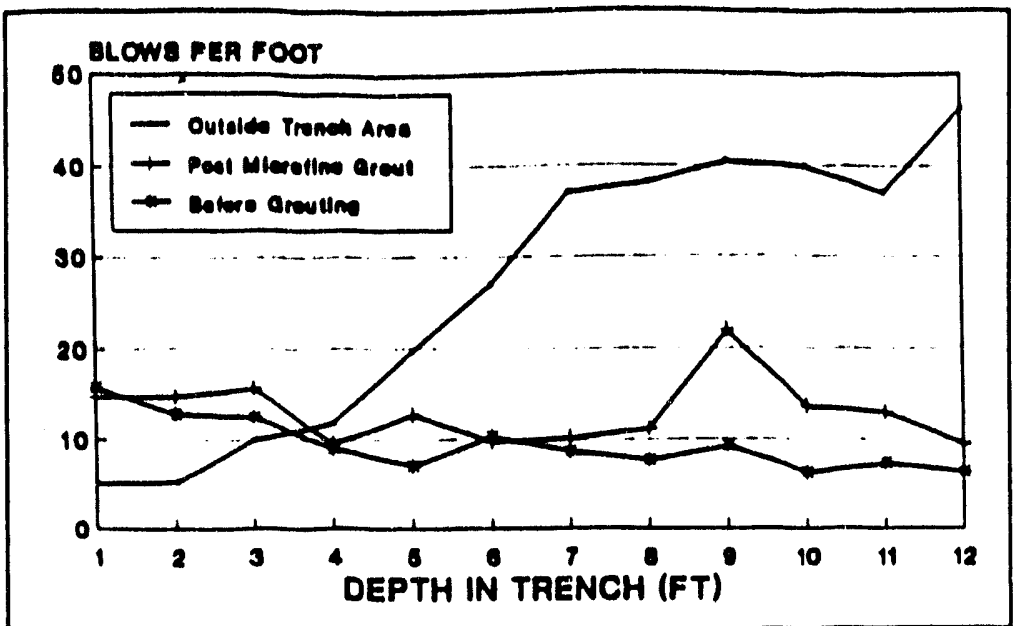

Fig. 30. Trench 148 soil penetration tests. and adjacent to the trenches averaged $6.4 \times 10^{-5} \mathrm{~cm} / \mathrm{s}$ indicating grouting of the trenches by either of the two methods (Portland Type I followed with CMFC or with CMFC by itself) did not result in measurements of hydraulic conductivity within the trench area equivalent to that of the natural soil.

Table 25. Measurements of hydraulic conductivity within and adjacent to the trenches

\begin{tabular}{ccc}
\hline Location & Well & $\begin{array}{c}\text { Hydraulic } \\
\text { conductivity } \\
(\mathrm{cm} / \mathrm{s})\end{array}$ \\
\hline Trench 170 & F-1 & $1.1 \times 10^{-3}$ \\
& F-2 & $1.1 \times 10^{-3}$ \\
& F-3 & $1.5 \times 10^{-3}$ \\
& F-4 & $1.1 \times 10^{-3}$ \\
\hline Trench 151 & F-5 & $6.6 \times 10^{-4}$ \\
& F-6 & $1.7 \times 10^{-3}$ \\
\hline Trench 148 & F-9 & $2.2 \times 10^{-3}$ \\
& F-10 & $7.1 \times 10^{-4}$ \\
& F-11 & $1.3 \times 10^{-3}$ \\
& F-13 & $2.4 \times 10^{-3}$ \\
\hline Outside trench area & M-1 & $1.1 \times 10^{-4}$ \\
& M-2 & $1.8 \times 10^{-5}$ \\
\hline
\end{tabular}




\section{SUMMARY AND CONCLUSIONS}

Low-level radwaste burial trenches were grouted with cement-based grouts to improve stability against long-term subsistence and to reduce hydraulic conductivity of the water into the trenches and potential transport of contaminants to groundwater. During the summer of 1990, two trenches (trenches 151 and 148) were grouted with a particulate-based grout made from Portland Type I cement, flyash, and Wyoming bentonite. Soil-penetration tests conducted before and after grouting of these trenches strongly indicated profound increases in trench stability. However, hydraulic conductivity measurements before and after grouting indicated grouting had not made a major impact in lowering the hydraulic conductivity within the trench area and some follow-up studies were recommended.

The following summer (1991), the same two trenches (trenches 151 and 170) previously grouted with the Portland Type I cement-based grout, were grouted again with another particulate-based grout made from a microfine cement (a fine grained cement $>50 \%$ by weight to be $<5 \mu \mathrm{m}$ diam) and Wyoming bentonite to fill the unfilled void spaces and reduce hydraulic conductivity within these trenches. The same clay-microfine-cement (CMFC) grout was also injected into a another trench (trench 148). The Portland Type I cement grout filled $\sim 17$ of the trench volume (trenches 151 and 170 ) and the CMFC grout filled $\sim 13$ of trench 148 volume (assuming trench depth of $10.4 \mathrm{ft})$.

Approximately $12 \mathrm{yd}^{3}$ of the CMFC was injected into the previously grouted trenches 151 and 170 with the expressed purpose of lowering hydraulic conductivity within these trenches. Measurements of hydraulic conductivity within trenches 151 and 170 after grouting with the CMFC grout averaged $1.2 \times 10^{-3} \mathrm{~cm} / \mathrm{s}$, considerably higher than average hydraulic conductivity in soil outside the trenches $\left(6.4 \times 10^{-5} \mathrm{~cm} / \mathrm{s}\right)$. Thus, these data indicate grouting with the clay-microfine cement did not reduce hydraulic conductivity to levels commonly observed in surrounding soils. The average hydraulic conductivity measured in the CMFC grouted 148 trench was approximately the same as that measured in the grouted 151 and 170 trenches $\left(1.7 \times 10^{-3} \mathrm{~cm} / \mathrm{s}\right)$ and much higher than the average measured in the surrounding soils, again indicating grouting with the CMFC grout did not appreciably lower hydraulic conductivity measurements in the trench. In addition, trench stability was not increased using the CMFC grout. For example, soil-penetration data from trench 148 before and after grouting with the CMFC grout revealed no significant difference $(P<0.5)$ in the number of blows to penetrate the distance of one foot indicating no benefits in increased trench stability from the CMFC grout.

These in-situ grouting studies of low-level burial trenches with cement-based grouts (using Portland Type I cement) have shown considerable benefit in increasing trench stability against potential future subsistence; however, little effect can be expected 
with regard to lowering hydraulic conductivity within the trenches, even if clay-based microfine cements are used as grouting materials. 


\section{REFERENCES}

American Nuclear Society. 1986. American National Standard Measurement of the Leachability of Solidified Low-Level Radioactive Wastes by a Short-Term Test Procedure. ANSII/ANS-16.1 American Nuclear Society, La Grange Park, Illinois.

Bechtel National, Inc. 1988. Closure plan for Solid Waste Storage Area 6. Vol. 1: Closure plan. ORNL/RAP/Sub-87/99053/9\&V1. Oak Ridge National Laboratory.

Davis, E. C., and B. P. Spalding. 1986. Field evaluation of a cement-bentonite grout and a chlorosulfonated polyethylene fabric liner in hydrologically isolating low-level radioactive solid waste. ORNL/TM 9742. Oak Ridge National Laboratory.

Davis, E. C., W. J. Boegly, Jr., E. R. Rothschild, B. P. Spalding, N. D. Vaughan, C. S. Haase, D. D. Huff, S. Y. Lee, E. C. Walls, and E. D. Smith. 1984. Site characterization techniques used at a low-level waste shallow land burial field demonstration facility. ORNL/TM-9146. Oak Ridge National Laboratory.

Krizek, R. J., and M. Helal. 1989. Some properties of microfine cement grouts. Civil Engineering Department, Northwest: $r n$ University, Evanston, Illinois (unpublished).

Lockwood Greene Engineers, Inc. 1988. Closure plan for Solid Waste Storage Area 6. Vol. 2: Interim corrective measures design. ORNL/RAP/Sub-87/99053/9\&V2/R1. Oak Ridge National Laboratory.

Luxmoore, R. J., B. P. Spalding, and I. L. Munro. 1981. Areal variation and chemical modification of weathered shale drainage characteristics. Soil Sci. Soc. Am. J. 45:687-691.

SAS. 1985. SAS User's Guide: Statistics, Version 5 Ediritun. SAS Institute, Inc., Cary, North Carolina.

Solomon, D. K., R. C. Haese, T. V. Dinsmore, and A. D. Kelmers. 1988. Sampling and analyses of SWSA 6 trench leachates and groundwaters. ORNL/TM-10813. Oak Ridge National Laboratory. 
Spalding, B. P. 1986. Burial trench dynamic compaction at a humid site. pp 676-689. In Proceedings of the Seventh Annual Participants' Information Meeting DOE Low-Level Waste Management Program. CONF-8509121. EG\&G Idaho Falls, Idaho.

Spalding, B. P. and T. A. Fontaine. 1992. Field demonstration of in situ grouting of radioactive solid waste burial trenches with polyacrylamide. pp. 415-425. In 2nd Volume. ASTM STP 1123, (Eds.) T. M. Gilliam and C. C. Wiles, American Society for Testing Materials, Philadelphia.

Spalding, B. P., L. K. Hyder, and I. L. Munro. 1985. Grouting as a remedial technique for buried low-level radioactive wastes. J. Environ. Qual. 14(3):389-396.

Spalding, B. P., G. K. Jacobs, and E. C. Davis. 1989. Demonstrations of technology for remediation and closure of Oak Ridge National Laboratory Waste Disposal Sites. ORNL/TM-11286. Oak Ridge National Laboratory.

Spalding, B. P., S. Y. Lee, C. D. Farmer, L. K. Hyder, and P. Supaokit. 1987. In situ grouting of buried transure:ic waste with polyacrylamide. pp. 39-76. In Oak Ridge Model Conference Proceedings. CONF-871075. Vol. 1, Pt 3. Martin Marietta Energy Systems, Inc., Oak Ridg?, Tennessee.

Tallent, O. K., E. W. McDaniel, R. D. Spence. 1987. Initial formulation results for in situ grouting of a waste trench at ORNL site No. 6. ORNL/TM-10299. Ozk Ridge National Laboratory.

Tamura, T., R. D. Spence, O. K. Tallent, and O. M. Sealand. 1987. In situ waste grouting of an ORNL trench using a particulate-type grout. ORNL/RAP-23. Oak Ridge National Laboratory.

Zebovitz, S., R. J. Krizek, and D. K. Atmoatzidis. 1989. Irjection of fine sands with very fine cement grout. J. Geotech. Eng. 115(12): :717-173:. 
APPENDICES

$=$
$=$
$=$
$=$ 
Appendix A

Soil Penetration Data after Grouting with Portland Type I Cement

\begin{tabular}{|c|c|c|c|c|c|c|c|}
\hline \multirow{2}{*}{$\begin{array}{l}\text { Soil } \\
\text { Depth } \\
\text { (ft) }\end{array}$} & \multirow{2}{*}{$\begin{array}{c}\text { Location } \\
\text { and } \\
\text { Type of Tea }\end{array}$} & \multirow{2}{*}{$\begin{array}{l}\text { Significance } \\
P<0.05^{\circ}\end{array}$} & \multicolumn{5}{|c|}{ Blows per Foot } \\
\hline & & & Ave. & $\operatorname{Max}$ & Min & xCV & $N$ \\
\hline \multirow[t]{3}{*}{1} & Outside & $\mathbf{B}$ & 5.1 & 8 & 2 & 26 & 51 \\
\hline & Pre-Grout & $\mathbf{B}$ & 5.1 & 10 & 3 & 33 & 22 \\
\hline & Post-Grout & $\mathbf{A}$ & 6.1 & 9 & 4 & 24 & 22 \\
\hline \multirow[t]{3}{*}{2} & Outside & A & 5.3 & 12 & 1 & 45 & 51 \\
\hline & Pre-Groul & A & 5.3 & 9 & 4 & 21 & 22 \\
\hline & Post-Grout & $\mathbf{A}$ & 6.4 & 9 & 4 & 21 & 22 \\
\hline \multirow[t]{3}{*}{3} & Outside & A & 10.0 & 37 & 2 & 69 & 51 \\
\hline & Pre-Grout & $\mathbf{A}$ & 9.8 & 22 & 5 & 40 & 22 \\
\hline & Post-Grout & $\mathbf{A}$ & 11.0 & 19 & 5 & 34 & 22 \\
\hline \multirow[t]{3}{*}{4} & Outside & A & 11.9 & 37 & 1 & 68 & 50 \\
\hline & Pre-Grout & $A$ & 11.0 & 22 & 6 & 39 & 22 \\
\hline & Post-Grout & $\mathbf{A}$ & 12.7 & 40 & 6 & 60 & 22 \\
\hline \multirow[t]{3}{*}{5} & Outside & $\mathbf{A}$ & 19.7 & 100 & 1 & 85 & 50 \\
\hline & Pre-Grout & B & 8.7 & 14 & 4 & 33 & 22 \\
\hline & Pox-Grout & $A$ & 17.1 & 74 & 6 & 93 & 22 \\
\hline \multirow[t]{3}{*}{6} & Outside & $\mathbf{A}$ & 26.9 & 100 & 7 & 62 & 49 \\
\hline & Pre-Grout & B & 10.8 & 53 & 4 & 91 & 22 \\
\hline & Pox-Grout & $A B$ & 18.6 & 100 & 4 & 110 & 22 \\
\hline \multirow[t]{3}{*}{7} & Outside & $\mathbf{A}$ & 37.0 & 100 & 7 & 64 & 48 \\
\hline & Pre-Grout & $\mathrm{C}$ & 8.8 & 14 & 4 & 34 & 22 \\
\hline & Pot-Grout & $\mathbf{B}$ & 20.4 & 90 & 4 & 109 & 21 \\
\hline \multirow[t]{3}{*}{8} & Outuide & $\mathbf{A}$ & 38.2 & 100 & 10 & 56 & 43 \\
\hline & Pre-Grout & $\mathbf{B}$ & 11.6 & 72 & 4 & 118 & 22 \\
\hline & Poat-Grout & $\mathbf{A}$ & 29.2 & 100 & 10 & 56 & 43 \\
\hline \multirow[t]{3}{*}{9} & Outuide & $\mathbf{A}$ & 39.9 & 100 & 12 & 50 & 33 \\
\hline & Pre-Grout & B & 11.7 & $25^{\circ}$ & 1 & 49 & 21 \\
\hline & Pox-Groul & $\mathbf{A}$ & 39.7 & 100 & 4 & 95 & 18 \\
\hline \multirow[t]{3}{*}{10} & Outside & $A$ & 39.9 & 100 & 12 & 50 & 33 \\
\hline & Pre-Grout & $\mathbf{B}$ & 14.5 & 41 & 4 & 72 & 21 \\
\hline & Post-Grout & $A$ & 35.0 & 100 & 5 & 87 & 14 \\
\hline
\end{tabular}


Appendix A

Soil Penetration Data after Grouting with Portland Type I Cement

\begin{tabular}{|c|c|c|c|c|c|c|c|}
\hline \multirow{2}{*}{$\begin{array}{l}\text { Soil } \\
\text { Depth } \\
\text { (ft) }\end{array}$} & \multirow{2}{*}{$\begin{array}{c}\begin{array}{c}\text { Location } \\
\text { and }\end{array} \\
\text { Type of Teat }\end{array}$} & \multirow{2}{*}{$\begin{array}{c}\text { Significance } \\
\mathrm{P}<0.05 \\
\end{array}$} & \multicolumn{5}{|c|}{ Blows per Foot } \\
\hline & & & Ave. & $\operatorname{Max}$ & Min & 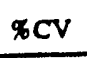 & $\mathbf{N}$ \\
\hline \multirow[t]{3}{*}{11} & Outride & $\mathbf{A}$ & 37.0 & 58 & 12 & 35 & 26 \\
\hline & Pre-Grout & $\mathbf{B}$ & 14.8 & 72 & 4 & 101 & 21 \\
\hline & Post-Grout & $\mathbf{A}$ & 43.7 & 100 & 13 & 65 & 13 \\
\hline \multirow[t]{3}{*}{12} & Outside & $\mathbf{A}$ & 46.2 & 100 & 10 & 50 & 23 \\
\hline & Pre-Grout & $\mathbf{B}$ & 16.8 & 58 & 4 & 77 & 20 \\
\hline & Post-Grout & $\mathbf{A}$ & 48.4 & 100 & 14 & 85 & 11 \\
\hline \multirow[t]{3}{*}{13} & Outside & $\mathbf{A}$ & 50.1 & 100 & 11 & 52 & 18 \\
\hline & Pre-Grout & B & 23.6 & 100 & 5 & 97 & 17 \\
\hline & Post-Grout & $\mathbf{A B}$ & 31.4 & 100 & 17 & 89 & 8 \\
\hline \multirow[t]{3}{*}{14} & Outuide & $\mathbf{A}$ & 38.3 & 100 & 12 & 67 & 10 \\
\hline & Pre-Grout & $\mathbf{B}$ & 21.9 & 49 & 7 & 65 & 14 \\
\hline & Pot-Grout & $\mathbf{A}$ & 46.3 & 78 & 21 & 48 & 7 \\
\hline \multirow[t]{3}{*}{15} & Outside & B & 35.7 & 68 & 15 & 49 & 7 \\
\hline & Pre-Grout & B & 36.2 & 84 & 9 & 61 & 12 \\
\hline & Poxt-Grout & A & 71.3 & 100 & 27 & 44 & 7 \\
\hline
\end{tabular}

-For each soil depth, means with the same letter are not significantly differene at $P<0.05$. 
Appeadix B

Soil Penetration Dalu after Grouting with CMFC

\begin{tabular}{|c|c|c|c|c|c|c|c|}
\hline \multirow{2}{*}{$\begin{array}{l}\text { Soil } \\
\text { Depth } \\
\text { (f) }\end{array}$} & \multirow{2}{*}{$\begin{array}{c}\text { Location } \\
\text { and } \\
\text { Time of Tex }\end{array}$} & \multirow{2}{*}{$\begin{array}{c}\text { Significance } \\
P<0.05^{\circ}\end{array}$} & \multicolumn{5}{|c|}{ Blows per Foot } \\
\hline & & & Ave. & Max & Min & \%cV & $\underline{N}$ \\
\hline \multirow[t]{3}{*}{1} & Outuide Trench & B & 5.1 & 8 & 2 & 26 & 51 \\
\hline & After Portland Type I & $\mathbf{B}$ & 6.1 & 9 & 4 & 24 & 22 \\
\hline & After CMFC & $A$ & 12.7 & 18 & 9 & 26 & 6 \\
\hline \multirow[t]{3}{*}{2} & Outside Trench & $\mathbf{B}$ & 5.3 & 12 & 1 & 45 & 51 \\
\hline & After Portland Type I & $\mathbf{B}$ & 6.4 & 9 & 4 & 21 & 22 \\
\hline & After CMFC & $\mathbf{A}$ & 13.2 & 20 & 9 & 28 & 6 \\
\hline \multirow[t]{3}{*}{3} & Outside Trench & $\mathbf{A}$ & 10.0 & 37 & 2 & 69 & 51 \\
\hline & After Portland Type I & $\mathbf{A}$ & 11.0 & 19 & 5 & 34 & 22 \\
\hline & After CMFC & $\mathbf{A}$ & 11.7 & 20 & 8 & 38 & 6 \\
\hline \multirow[t]{3}{*}{4} & Outuide Trench & $\mathbf{A}$ & 11.9 & 37 & 1 & 68 & so \\
\hline & After Portiand Type I & $\mathbf{A}$ & 12.7 & 40 & 6 & 60 & 22 \\
\hline & After CMFC & $\mathbf{A}$ & 11.3 & 19 & 6 & 50 & 6 \\
\hline \multirow[t]{3}{*}{5} & Outside Trench & $\mathbf{A}$ & 19.7 & 100 & 1 & 85 & so \\
\hline & After Portand Typo I & $\mathbf{A}$ & 17.1 & 74 & 6 & 93 & 22 \\
\hline & After CMFC & $A$ & 11.2 & 18 & 6 & 49 & 6 \\
\hline \multirow[t]{3}{*}{6} & Outside Trench & $\mathbf{A}$ & 26.9 & 100 & 7 & 62 & 49 \\
\hline & After Portland Type I & $A$ & 18.6 & 100 & 4 & 110 & 22 \\
\hline & After CMFC & $\mathbf{A}$ & 13.5 & 41 & 5 & 101 & 6 \\
\hline \multirow[t]{3}{*}{7} & Outuide Trench & $\mathbf{A}$ & 37.0 & 100 & 7 & 64 & 48 \\
\hline & After Portland Type I & $\mathbf{A B}$ & 20.4 & 90 & 4 & 109 & 21 \\
\hline & After CMFC & B & 12.0 & 27 & 4 & 80 & 6 \\
\hline \multirow[t]{3}{*}{8} & Outside Trench & $\mathbf{A}$ & 38.2 & 100 & 10 & 56 & 43 \\
\hline & After Portand Type I & $\mathbf{A}$ & 29.2 & 100 & 10 & 56 & 43 \\
\hline & After CMFC & $\mathbf{A}$ & 23.8 & 70 & 5 & 103 & 6 \\
\hline \multirow[t]{3}{*}{9} & Outuide Trench & $\mathbf{A}$ & 39.9 & 100 & 12 & so & 33 \\
\hline & After Portind Type I & $A$ & 39.7 & 100 & 4 & 95 & 18 \\
\hline & After CMFC & $\mathbf{A}$ & 55.7 & 100 & 8 & 73 & 6 \\
\hline
\end{tabular}


Appendix B

Soil Penetration Data after Grouting with CMFC

\begin{tabular}{|c|c|c|c|c|c|c|c|}
\hline \multirow{2}{*}{$\begin{array}{l}\text { Soil } \\
\text { Depth } \\
\text { (f) }\end{array}$} & \multirow{2}{*}{$\begin{array}{c}\begin{array}{c}\text { Location } \\
\text { and } \\
\text { Time of Teat }\end{array} \\
\end{array}$} & \multirow{2}{*}{$\begin{array}{c}\text { Significance } \\
\mathrm{P}<0.05 \\
\end{array}$} & \multicolumn{5}{|c|}{ Blows per Foor } \\
\hline & & & Ave. & Max. & Min. & $\% \mathrm{CV}$ & $\mathbf{N}$ \\
\hline \multirow[t]{3}{*}{10} & Outside Trench & $\mathbf{A}$ & 39.9 & 100 & 12 & so & 33 \\
\hline & After Porllend Type I & $\mathbf{A}$ & 35.0 & 100 & 5 & 87 & 14 \\
\hline & After CMFC & $\mathbf{A}$ & 20.8 & 28 & 10 & 37 & 4 \\
\hline \multirow[t]{3}{*}{11} & Outside Trench & $\mathbf{A}$ & 37.0 & 58 & 12 & 35 & 26 \\
\hline & After Portland Type I & $\mathbf{A}$ & 43.7 & 100 & 13 & 65 & 13 \\
\hline & Afler CMFC & $\mathbf{A}$ & 32.2 & 49 & 22 & 36 & 4 \\
\hline \multirow[t]{3}{*}{12} & Outside Trench & $\mathbf{A}$ & 46.2 & 100 & 10 & so & 23 \\
\hline & After Portland Type I & $\mathbf{A}$ & 48.4 & 100 & 14 & 85 & 11 \\
\hline & After CMFC & $\mathbf{A}$ & 28.5 & 42 & 20 & 34 & 4 \\
\hline
\end{tabular}

'For each soil depth, means with the same letuer are not significantly different at $P<0.05$. 
79

APPENDDX C

Soil Penetration Dain from Trench 148

\begin{tabular}{|c|c|c|c|c|c|c|c|}
\hline \multirow{2}{*}{$\begin{array}{l}\text { Soil } \\
\text { Depth } \\
\text { (ft) }\end{array}$} & \multirow{2}{*}{$\begin{array}{c}\begin{array}{c}\text { Location } \\
\text { and }\end{array} \\
\text { Type of Tea } \\
\end{array}$} & \multirow{2}{*}{$\begin{array}{c}\text { Significance } \\
\text { P }<0.05^{\circ} \\
\end{array}$} & \multicolumn{5}{|c|}{ Blows per Food } \\
\hline & & & Ave. & Max & Min & xcV & $\mathrm{N}$ \\
\hline \multirow[t]{3}{*}{1} & Outside Trench & B & 5.1 & 8 & 2 & 25.8 & 51 \\
\hline & Pre-Grout & $\mathbf{A}$ & 15.8 & 18 & 12 & 18.2 & 4 \\
\hline & Pon-Grout & $\mathbf{A}$ & 14.7 & 20 & 10 & 22.7 & 6 \\
\hline \multirow[t]{3}{*}{2} & Outside Trench & B & 5.3 & 12 & 1 & 45.2 & si \\
\hline & Pre-Grout & $A$ & 12.8 & 16 & 11 & 18.5 & 4 \\
\hline & Post-Gmut & $A$ & 14.7 & 17 & 9 & 19.6 & 6 \\
\hline \multirow[t]{3}{*}{3} & Outside Trench & $\mathbf{A}$ & 10.0 & 37 & 2 & 69.1 & 51 \\
\hline & Pre-Grout & $A$ & 12.5 & 18 & 10 & 29.6 & 4 \\
\hline & Pox-Grout & $\mathbf{A}$ & 15.7 & 20 & 12 & 19.2 & 6 \\
\hline \multirow[t]{3}{*}{4} & Outside Trench & $A$ & 11.9 & 37 & 1 & 67.8 & 50 \\
\hline & Pre-Groul & $\mathbf{A}$ & 9.0 & 13 & 3 & 40.6 & 4 \\
\hline & Post-Grout & $A$ & 9.5 & 14 & 6 & 28.0 & 6 \\
\hline \multirow[t]{3}{*}{5} & Outside Trench & $A$ & 19.7 & 100 & 1 & 85.1 & 50 \\
\hline & Pre-Grout & $\mathbf{A}$ & 7.0 & 10 & 6 & 28.6 & 4 \\
\hline & Pout-Grout & $\mathbf{A}$ & 12.7 & 25 & 5 & 54.8 & 6 \\
\hline \multirow[t]{3}{*}{6} & Outuide Trench & $\mathbf{A}$ & 26.9 & 100 & 7 & 61.7 & 49 \\
\hline & Pre-Grout & $\mathbf{A}$ & 10.3 & 22 & 6 & 76.6 & 4 \\
\hline & Post-Grout & $\mathbf{A}$ & 9.7 & 21 & 4 & 61.3 & 6 \\
\hline \multirow[t]{3}{*}{7} & Outside Trench & $A$ & 37.0 & 100 & 7 & 64.3 & 48 \\
\hline & Pre-Grout & B & 8.7 & 12 & 7 & 33.3 & 3 \\
\hline & Post-Grout & B & 10.2 & 19 & 3 & en.8 & 6 \\
\hline \multirow[t]{3}{*}{8} & Outside Trench & A & 38.2 & 100 & 10 & 55.9 & 43 \\
\hline & Pre-Grout & B & 7.7 & 12 & 4 & 52.7 & 3 \\
\hline & Pout-Grous & B & 11.2 & 33 & 4 & 99.3 & 6 \\
\hline \multirow[t]{3}{*}{9} & Outeide Trench & $A$ & 40.5 & 100 & 9 & 46.4 & 39 \\
\hline & Pre-Grout & B & 9.3 & 15 & 2 & 71.3 & 3 \\
\hline & Poat-Grout & $A B$ & 22.0 & 80 & 5 & 148.0 & $s$ \\
\hline
\end{tabular}


80

APPENDLX C

Soil Penetration Datí from Trench 148

\begin{tabular}{|c|c|c|c|c|c|c|c|}
\hline \multirow{2}{*}{$\begin{array}{l}\text { Soil } \\
\text { Depth } \\
\text { (f) }\end{array}$} & \multirow{2}{*}{$\begin{array}{c}\text { Location } \\
\text { and } \\
\text { Type of Tex }\end{array}$} & \multirow{2}{*}{$\begin{array}{c}\text { Significance } \\
P<0.05 \\
\end{array}$} & \multicolumn{5}{|c|}{ Blows per Foot } \\
\hline & & & Ave. & Max & Min & \$CV & $\mathbf{N}$ \\
\hline \multirow[t]{3}{*}{10} & Outside Trench & $\mathbf{A}$ & 39.9 & 100 & 12 & 50.3 & 33 \\
\hline & Pre-Grout & B & 6.3 & 12 & 1 & 87.0 & 3 \\
\hline & Pout-Grout & B & 13.6 & 27 & 4 & 70.3 & 5 \\
\hline \multirow[t]{3}{*}{11} & Outside Trench & $\mathbf{A}$ & 37.0 & 58 & 12 & 35.0 & 26 \\
\hline & Pre-Grout & B & 7.3 & 11 & 1 & 75.1 & 3 \\
\hline & Post-Grout & B & 13.0 & 26 & 4 & 69.9 & 5 \\
\hline \multirow[t]{3}{*}{12} & Outride Trench & $\mathbf{A}$ & 46.2 & 100 & 10 & 50.0 & 23 \\
\hline & Pre-Grout & B & 6.3 & 10 & 2 & 63.8 & 3 \\
\hline & Pou-Grout & B & 9.4 & 21 & 3 & 75.8 & 5 \\
\hline
\end{tabular}

'For each soil depth, means with the same letter are not significantly different at $\mathrm{P}<0.05$. 


\section{INTERNAL DISTRIBUTION LIST}

1. H. L. Adair

2. H. L. Boston

3. N. H. Cutshall

4. C. D. Farmer

5. C. J. Ford

6-12. C. W. Francis

13. S. B. Garland

14. D. D. Gates

15. D. F. Hall

16. S. G. Hildebrand

17. E. W. McDaniel

18. A. P. Malinauskas

19. C. A. Manrod

20. D. S. Marshall

21. B. C. McCelland
22. L. E. McNeese

23. D. E. Reichle

24. T. F. Scanlan

25-30. B. P. Spalding

31-33. R. D. Spence

34. S. H. Stow

35-39. T. Tamura

40. J. R. Trabalka

41. S. D. Van Hoesen

42. Central Research Library

43-58. ESD Library

59-60. Laboratory Records Dept.

61. Laboratory Records, ORNL-RC

62. ORNL Patent Section

63. ORNL Y-12 Technical Library

\section{EXTERNAL DISTRIBUTION}

64. E. F. Barth, U.S. Environmental Protection Agency, 26 M. L. King Dr., Cincinnati, OH 45268

65. W. F. Bonner, Battele Pacific Northwest Laboratories, P. O. Box 999, Richland, WA 99352

66. J. L. Buelt. Battelle Pacific Northwest Laboratories, P. O. Box 999, Richland WA 99352

67. E. Cox, Tennessce Department of Health and Environment, 701 Broadway, 4th Floor, Customs House, Nashville, TN 37219-5403

68. J. F. Franklin, Bloedel Professor of Ecosystem Analysis, College of Forest Resources, University of Washington, Anderson Hall AR-10, Seattle, WA 98195

69. Clayton Gist, U. S. Department of Energy, Oak Ridge Operations, P.O. Box 2001, Oak Ridge, TN 37831

70. R. C. Harriss, Institute for the Study of Earth, Oceans, and Space, Science and Engineering Research Building, University of New Hampshire, Durham, NH 03824 
71. G. Y. Jordy, Director, Office of Program Analysis, Office of Energy Research, ER-30, G-226, U. S. Department of Energy, Washington, DC 20545

72. Emil Kowalski, Division Head, Repository Projects, NAGRA, Parkstrasse 23, $\mathrm{CH}-401$, Baden, Switzerland

73. G. Loomis, EG\&G Idaho, Inc., PO. Box 1625, Idaho Falls, ID 83415

74. Peter Manchak, P. O. Box 21708, Santa Barbara, CA 93121

75. R. H. Olsen, Professor, Microbiology and Immunology Department, University of Michigan, Medical Sciences II, \#5605, 1301 East Catherine Street, Ann Arbor, MI 48109-0620

76. A. Patrinos, Director, Environmental Sciences Division, Office of Health and Environmental Research, ER-74, U.S. Department of Energy, Washington, DC 20585

77. T. J. Wheeler, U. S. Department of Energy, Oak Ridge Operations, P. O. Box 2001, Oak Ridge, TN 37831

78. F. J. Wobber, Environmental Sciences Division, Office of Health and Environmental Research, ER-74, U. S. Department of Energy, Washington, DC 20585

79. Office of Assistant Manager for Energy Research and Development, U. S. Department of Energy Oak Ridge Field Office, P. O. Box 2001, Oak Ridge, TN 37831-8600

80-89. Office of Scientific and Technical Information, P.O. Box 62, Oak Ridge TN 37831. 

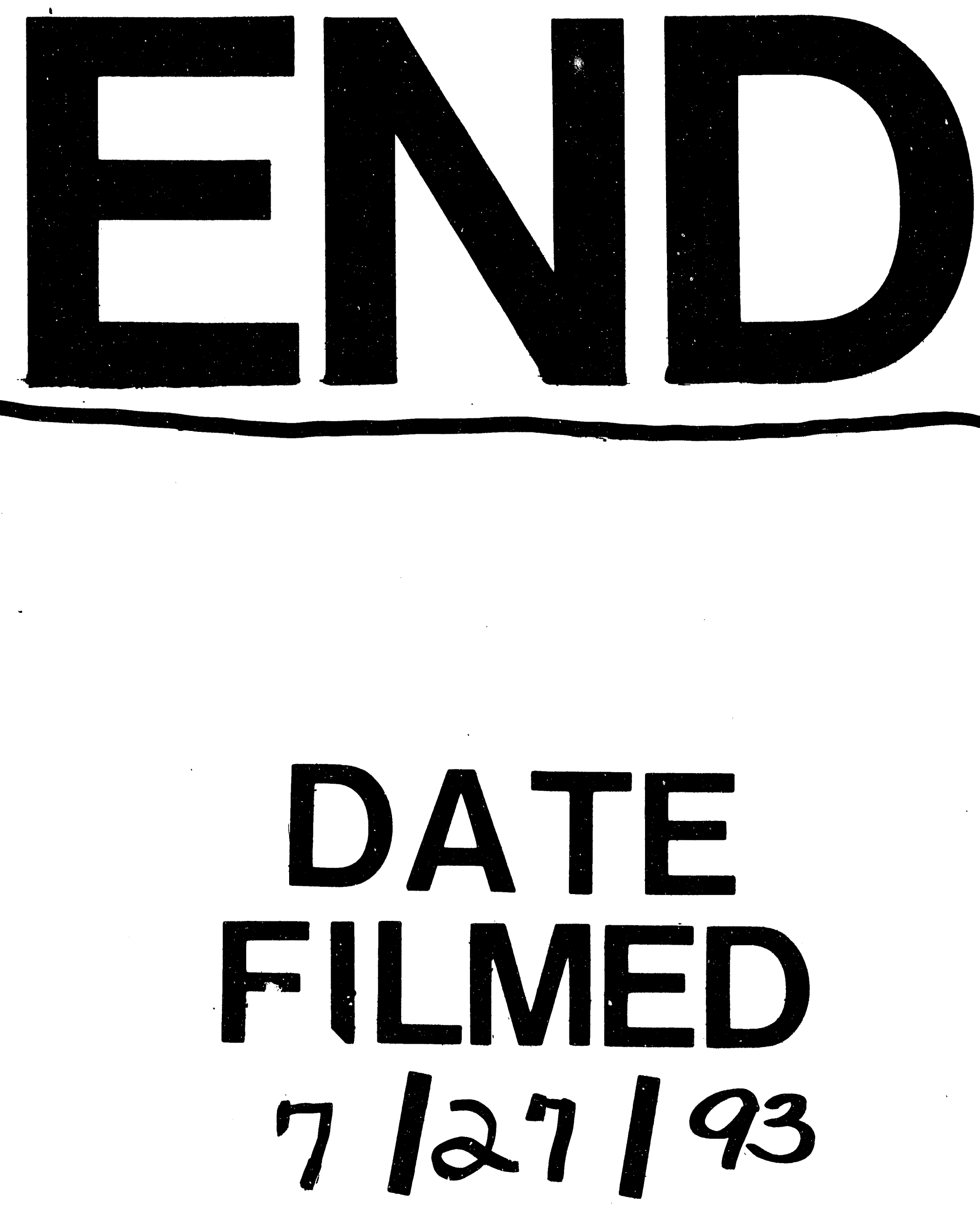

音 
